\title{
تطوير تدريب الموجهين الفنيين بـالتعليم الثانوي بـاككويت في ضوء متطلبات مجتمع المعرفة
}

\author{
إعداد \\ د/ رشّاد أبو المجلد مصطفى \\ مدرس اصول التربية - كلية التربية بقنا

$$
\text { جامعة جنوب الو ادي }
$$ \\ rahadmostafa@edu.svu.edu \\ أ/ سوزان جاسم عبد الحسين بـاباجان \\ باحثة لارجة الماجستير تخصص أصول التربية

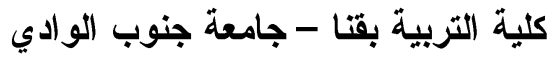 \\ Omaqeel05@gmail.com \\ أ. د/ فتحي عبد الرسول محمد

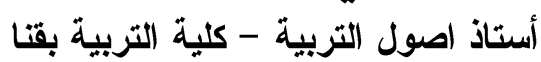

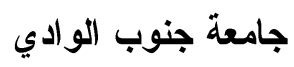 \\ fthee55555@yahoo.com

$$
\begin{aligned}
& \text { د/ فاطمة محمد البردويلي } \\
& \text { جامعة جنوب الو ادي }
\end{aligned}
$$$$
\text { مدرس اصول التربية - كلية التربية بقنا }
$$ 


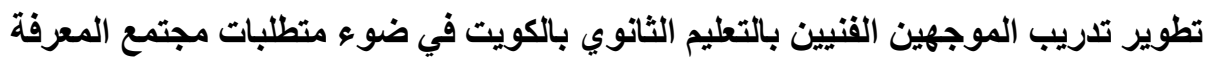
أ. د/فتحي عبدالرسول محمد د/رشاد أبو المجد مصطفى د/فاطمة محمد البردويلي ألر سوزان جاسم عبدالحسين باباتجان

\section{تطوير تلدريب الموجهين الفنيين بـالتعليه الثانوي بالكويت في ضوء متطلبات مجتمع المعرفة}

\section{د/ رشاد أبو المجلد مصطفى}

مدرس اصول التربية - كلية التربية بقنا

$$
\text { جامعة جنوب الو ادي }
$$

rahadmostafa@edu.svu.edu

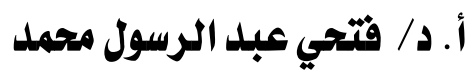

أستاذ اصول التربية - كلية التربية بقنا جامعة جنوب الو ادي

fthee55555@yahoo.com

\section{أ/ سوزان جاسم عبد الحسين باباجاز} باحثة لارجة الماجستير تخصص أصول التربية

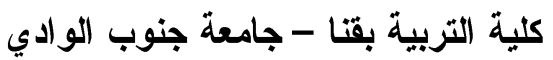

Omaqeel05@gmail.com

\section{د/ فاطمة محمد البردوبلي}

مدرس اصول التربية - كلية التربية بقنا جامعة جنوب الو ادي الئر

fatmabardawely@edu.svu.edu المستخلص :

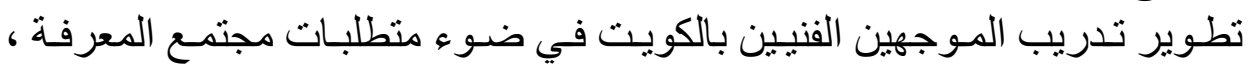

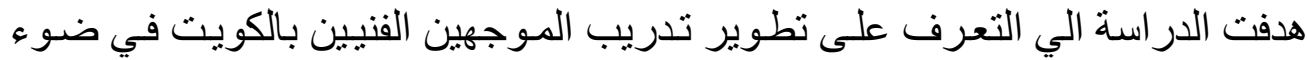

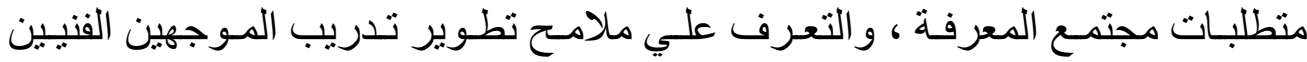

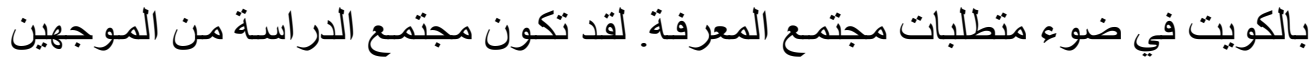

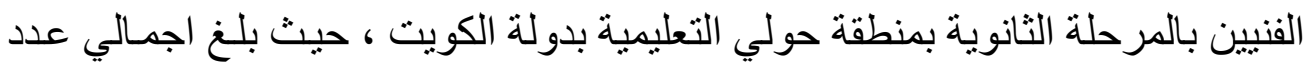

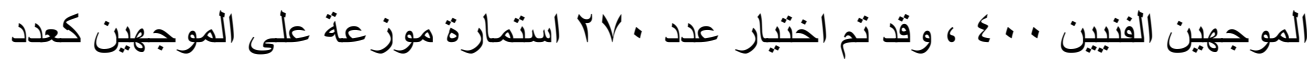

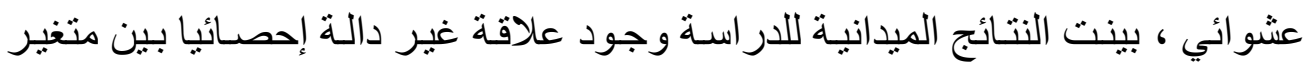

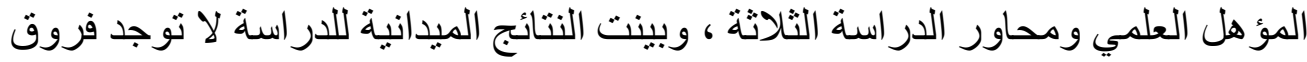

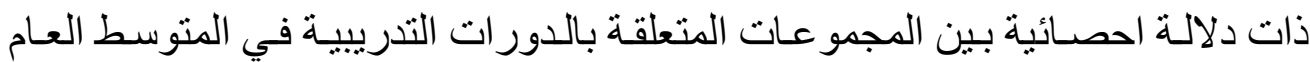

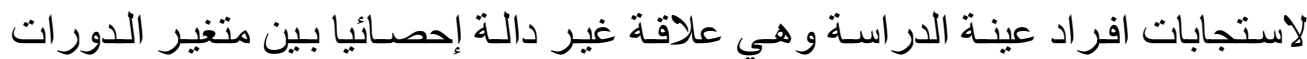

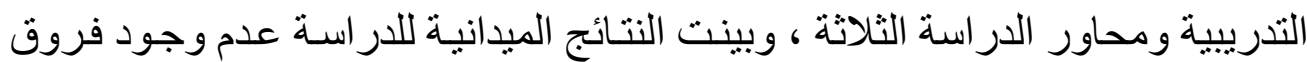
ذات دلالة احصائية بين متوسط استجابات الموجهين الفنيين حول محساور الدراسـة مهـا

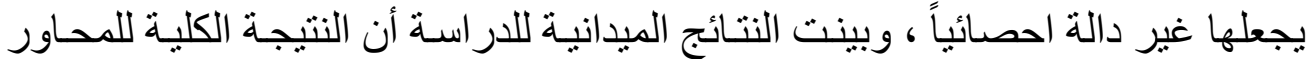
الثلاثة فتظهر عدم وجود فروق ذات دلالة احصائية بين استجابات مجتمع الدراسة.

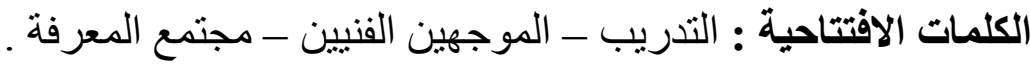




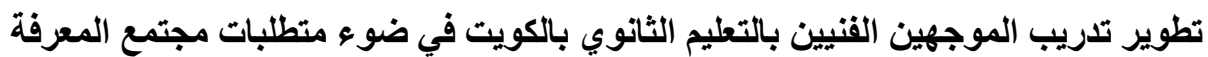
أ. د/فتحي عبدالرسول محمد د/رشاد أبوالمجد مصطفى د/فاطمة محمد البردويلي أ/ سوزان جاسم عبدالحسين باباجان

\title{
Developing training of technical mentors in Kuwait in light of the requirements of a knowledge society
}

\author{
Preparation \\ Prof. Dr.: Fathi Abdel-Rasoul \\ Department Fundamentals of Education \\ Faculty of Education, Qena \\ South Valley University \\ fthee55555@yahoo.com \\ Dr. Fatima Al-Bardawili \\ Department Fundamentals of Education \\ Faculty of Education, Qena \\ South Valley University \\ fatmabardawely@edu.svu.edu

\section{Dr. Rashad AboEl-Magd} \\ Department Fundamentals of Education \\ Faculty of Education, Qena \\ South Valley University \\ rahadmostafa@edu.svu.edu \\ Susan Jassim Babajan \\ Researcher for a master's degree in education, \\ specializing in the principles of education \\ Faculty of Education- South Valley University \\ Omaqeel05@gmail.com
}

\section{Abstract:}

Developing training of technical mentors in Kuwait in light of the requirements of a knowledge society, The study aimed to identify the development of technical mentors training in Kuwait in the light of the requirements of the knowledge society, and to identify the features of developing the technical mentors training in Kuwait in the light of the requirements of the knowledge society. The study population consisted of technical mentors in the secondary stage in Hawalli Educational Zone in the State of Kuwait, where the total number of technical mentors reached 400, and the number of 270 forms distributed to the mentors was chosen as a random number.The field results of the study indicated the presence of a statistically insignificant relationship between the variable of the academic qualification and the three axes of the study, and the field results of the study showed that there were no statistically significant differences between the groups related to training courses in the general average of the responses of the study sample individuals, which is a statistically significant relationship between the variable of training courses and the study axes The three results of the study showed that there were no statistically significant differences between the average responses of the technical mentors around the study axes, which makes them statistically insignificant.

Keywords : Training - Technical Mentors - Knowledge Society 


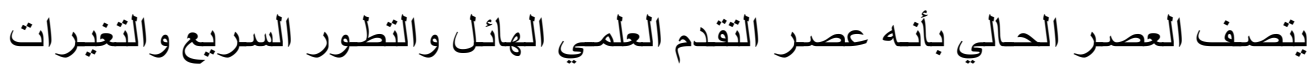

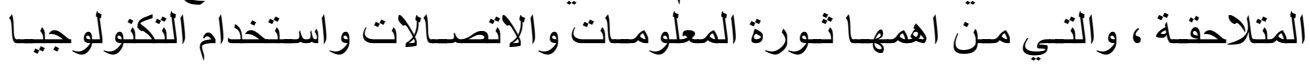

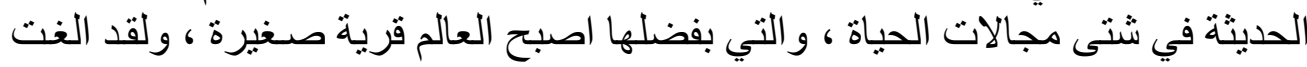

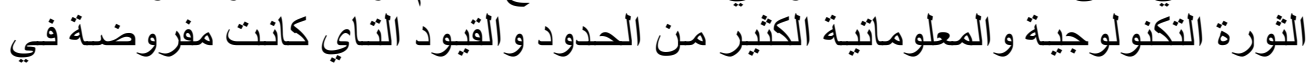

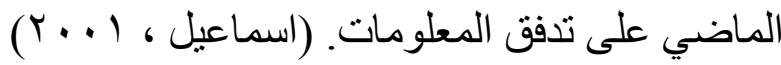

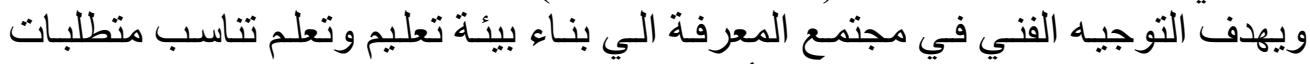

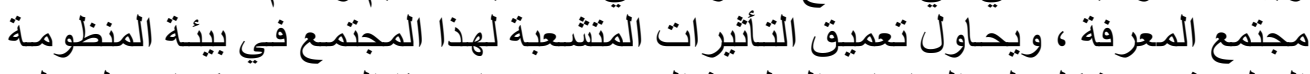

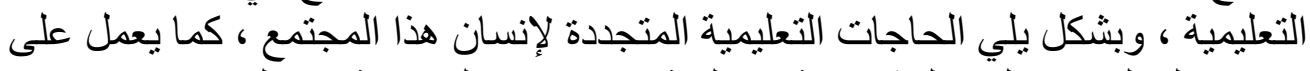

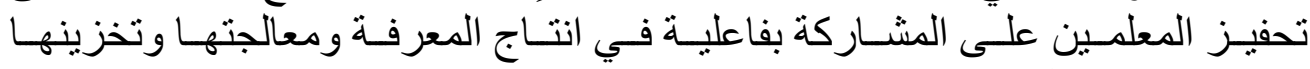

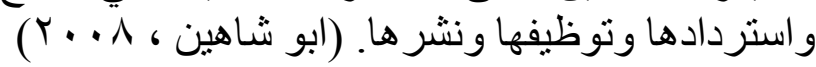

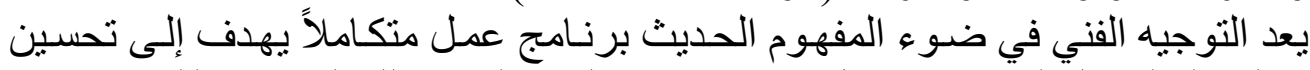

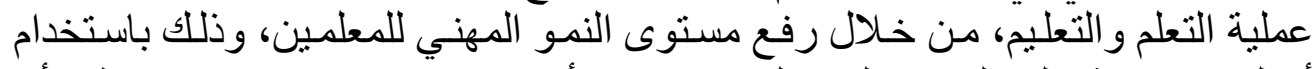

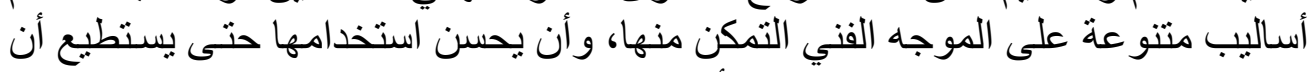

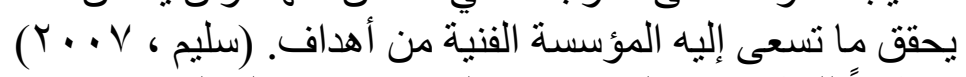

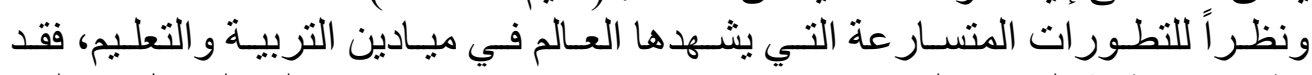

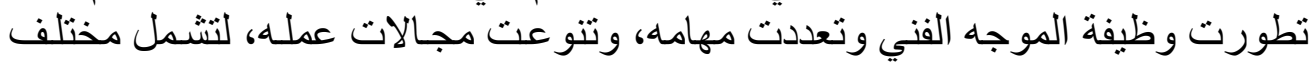

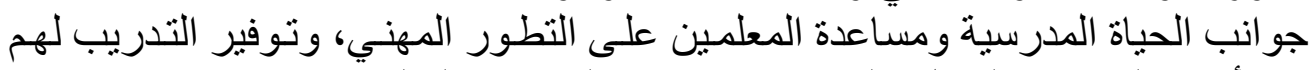

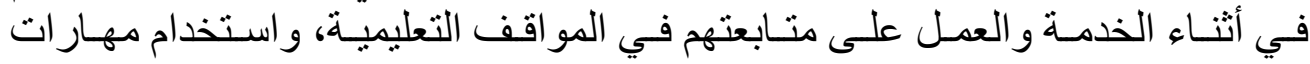

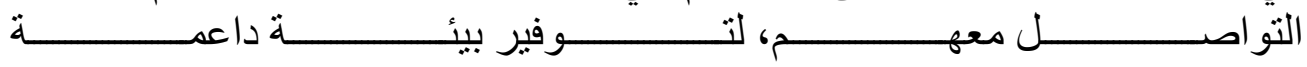

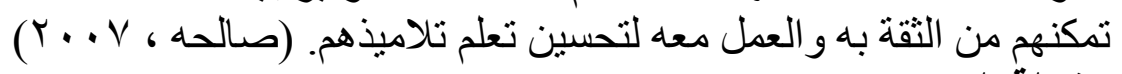

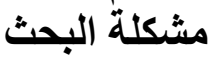

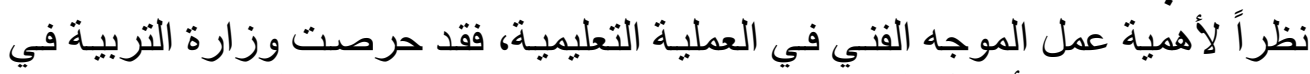

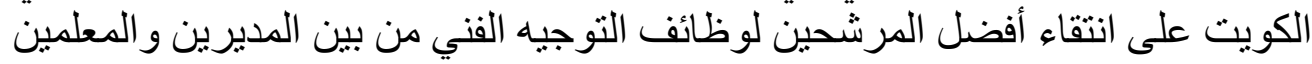

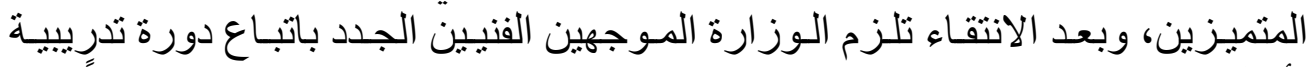

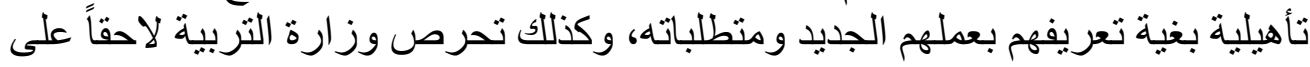

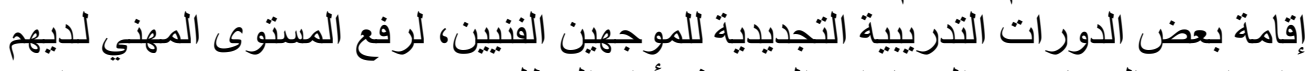

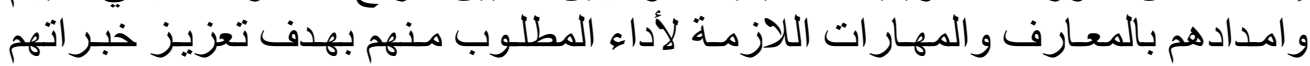

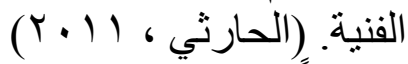

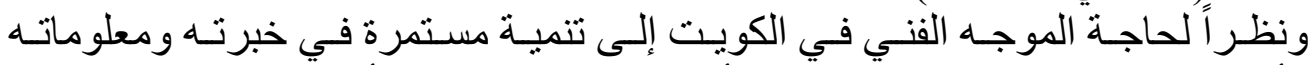

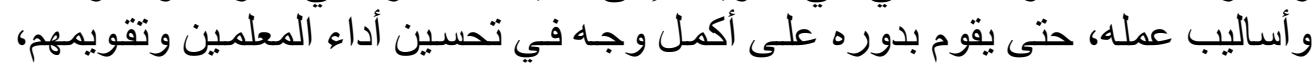

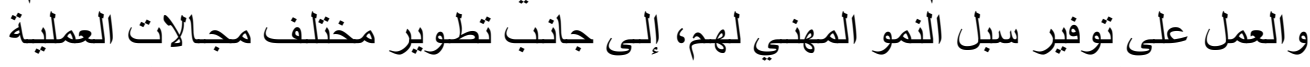

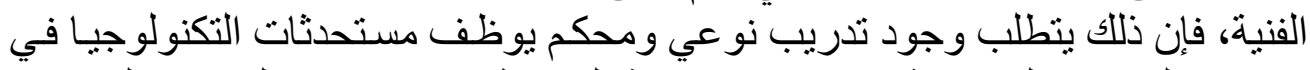

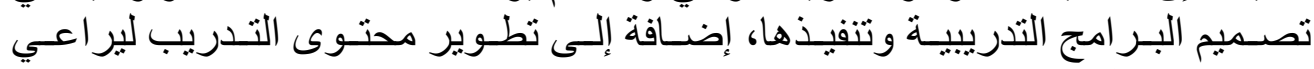

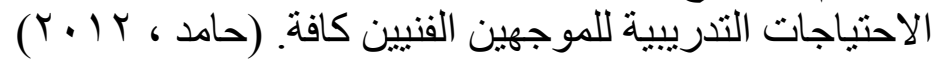




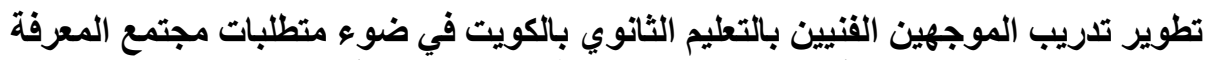

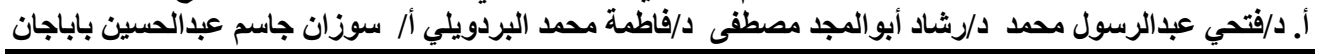

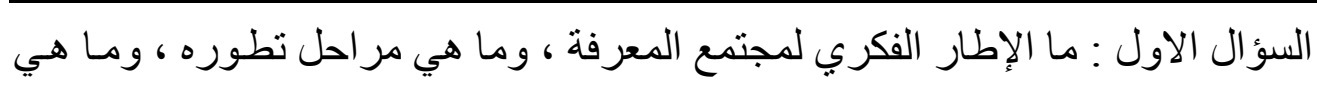

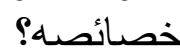
السؤال الثاني : ما الإطار الفكري لتدريب الموجهين الفنيين بالتعليم الثانوي في الكويت

السؤال الثالث : ما واقع تدريب الموجهين الفنيين بالتعليم الثانوي ؟ وما مشكلاته ؟

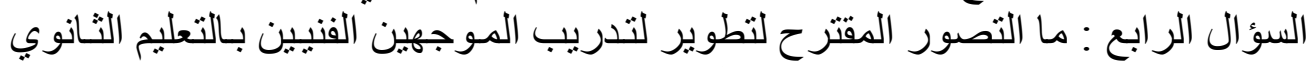

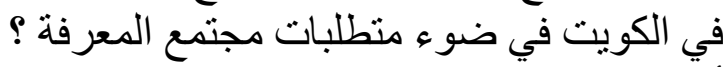
أهداف البحث

ا. التعرف على الإطار الفكري لمجتمع المعرفة ، ومـا هي مر احل تطوره ، ومـا

$$
\text { هي خصائصه. }
$$

Y. التعرف على الإطـار الفكري لتدريب الموجهين الفنيين بـالتعليم الثانوي في

$$
\text { الكويت. }
$$

r. التعرف على و اقع تدريب الموجهين الفنيين بالتعليم الثانوي و ومشكلاته.

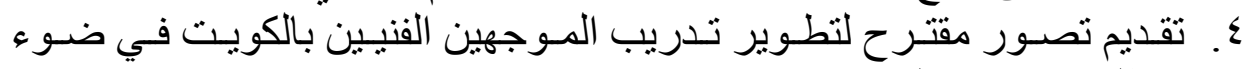
متطلبات مجتمع المعرفة. تظهر أهمية الدر اسة فيما يلي : الهيث

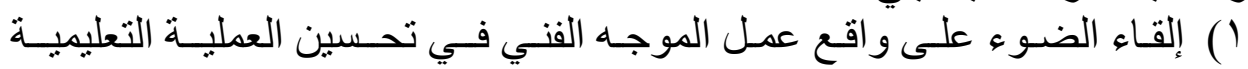
وتطوير ها.

Y) أهمية عمل الموجه الفني في تحقيق النمو المهني للمعلم و الارتقاء بأدائهه ودوره في تطوير مختلف جوانب التعلية التربوية.

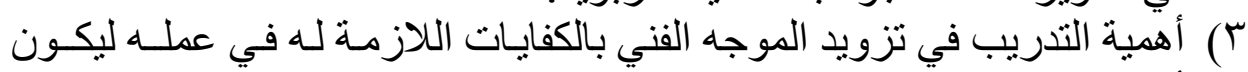

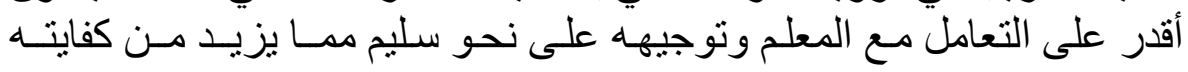
و إنتاجيته.

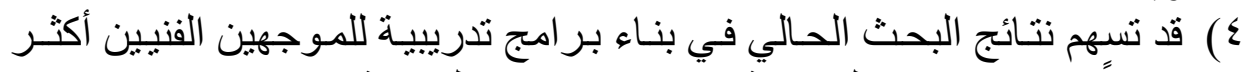

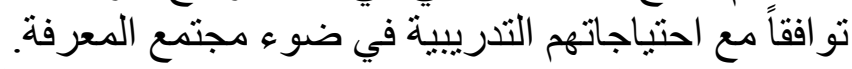

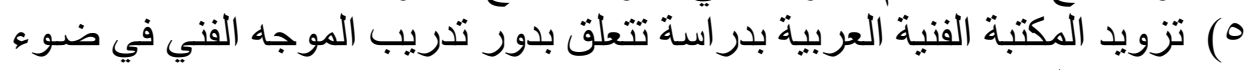
منهجية البحث مجنمع المعرفة.

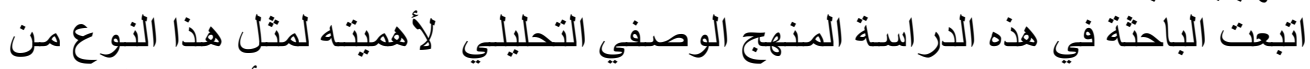

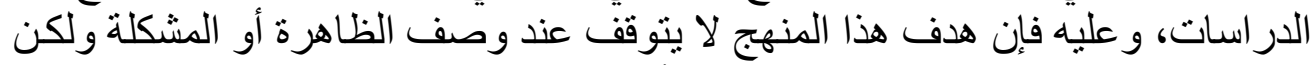

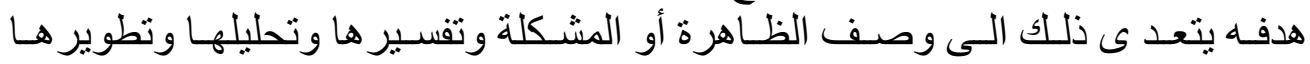

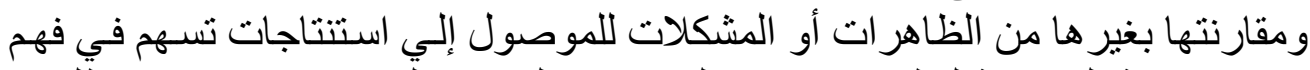

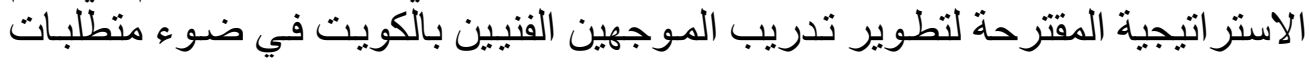
مجتمع المعرفة. 


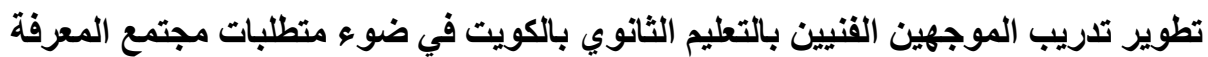
أ. د/فتحي عبدالرسول محمد د/رشاد أبو المجد مصطفى د/فاطمة محمد البردويلي أل/ سوزان جاسم عبداكئ الحسين باباجان

\section{الإطار النظري للبحث

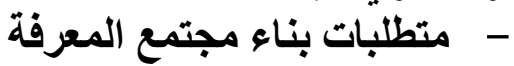

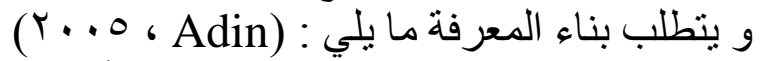

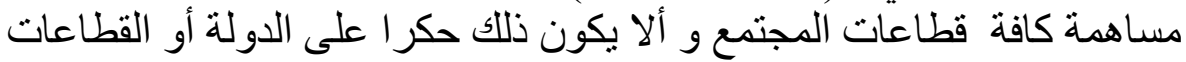

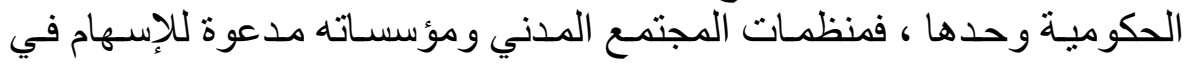

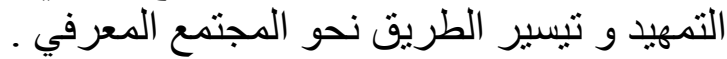

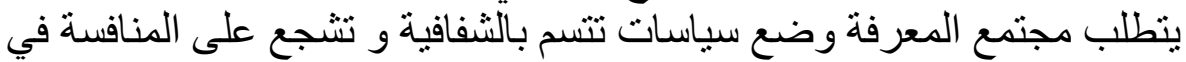

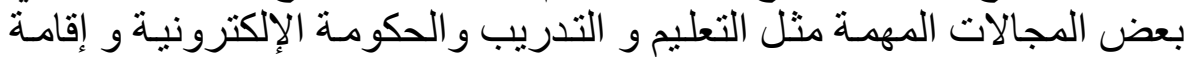

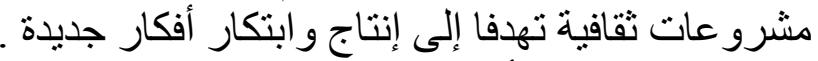

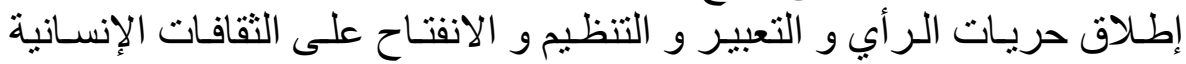

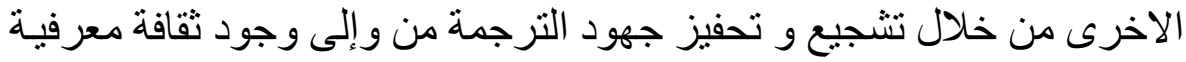

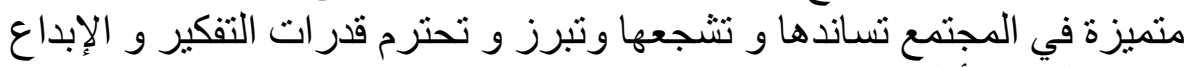

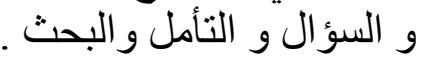

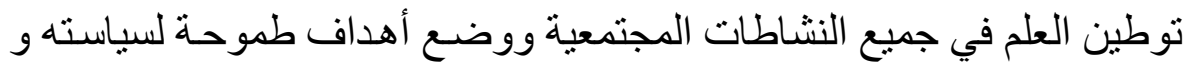

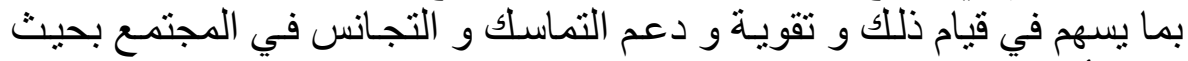

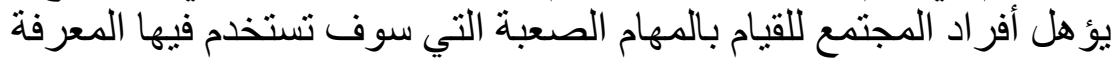

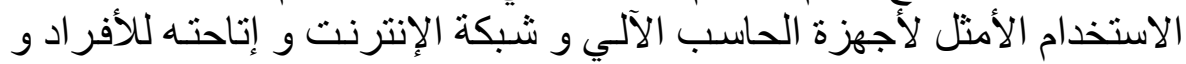

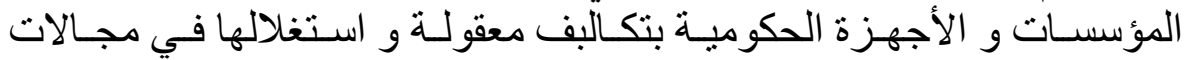

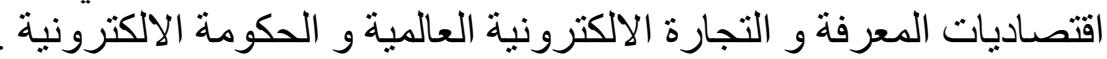

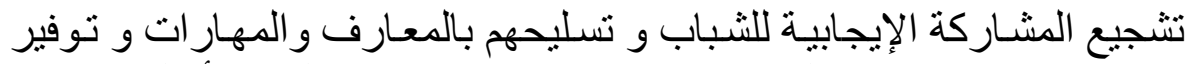

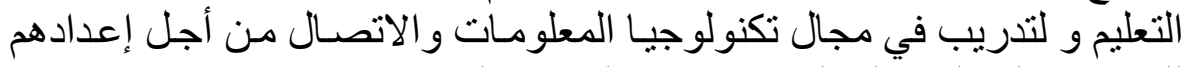

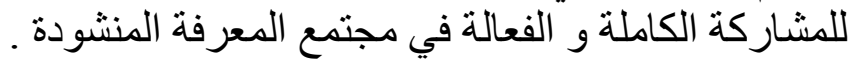

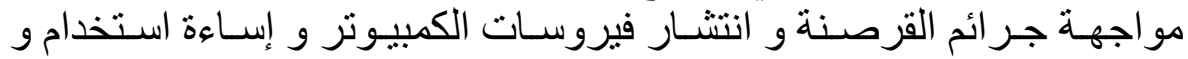

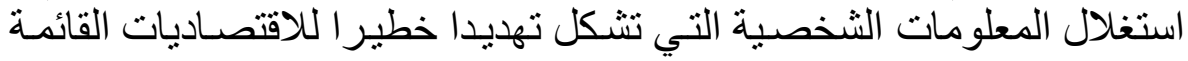

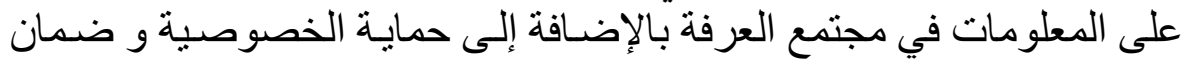

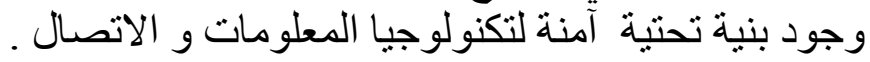
وتتحدد متطلبات بناء مجتمع المعرفة ذاتها والمتمثلة في الآتي :

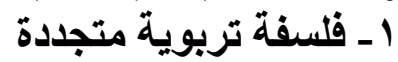

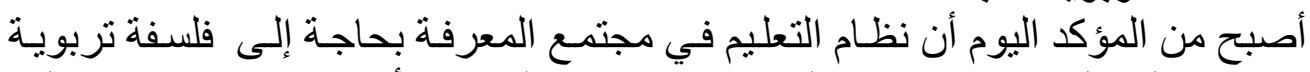

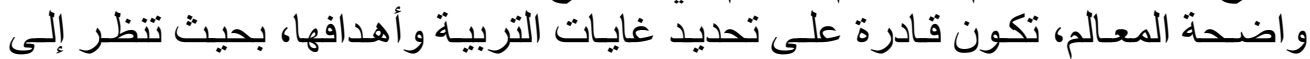

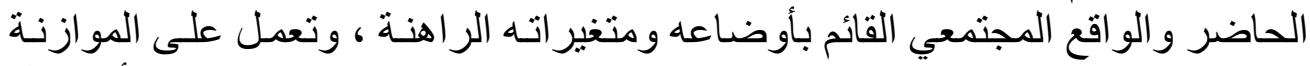

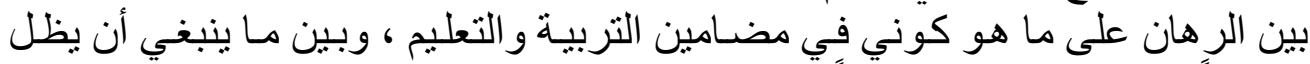

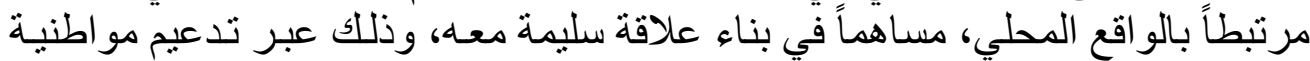

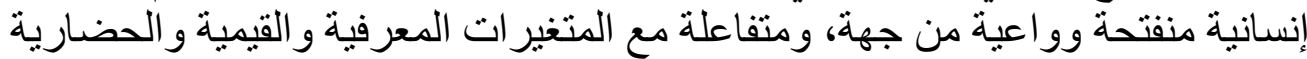

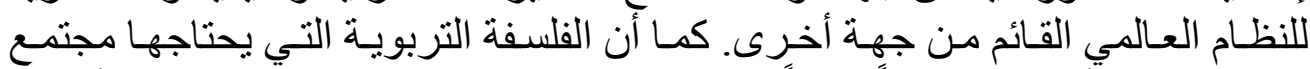

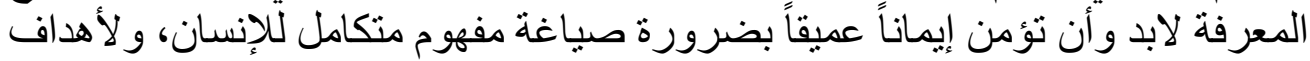




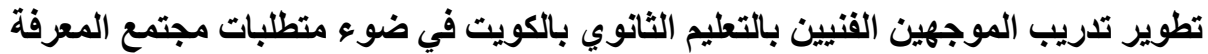
أ. د/فتحي عبدالرسول محمد د/رشاد أبو المجد مصطفى د/فاطمة محمد البردويلي ألر سوزان جاسم عبدالحسين باباتجان

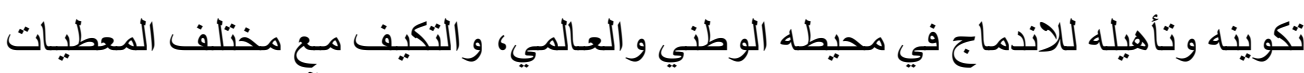

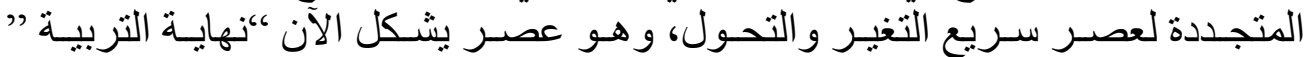

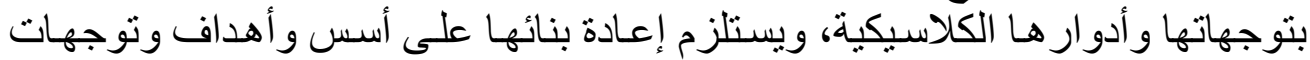

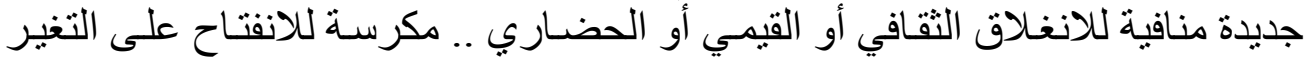

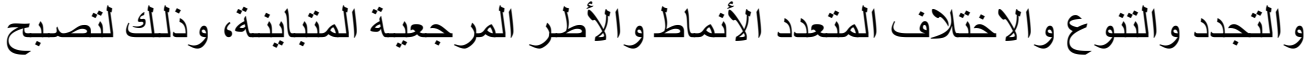

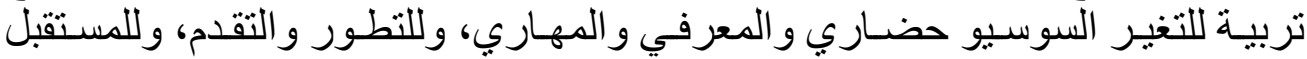

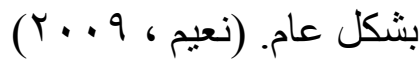

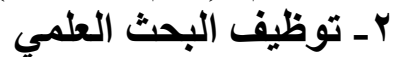

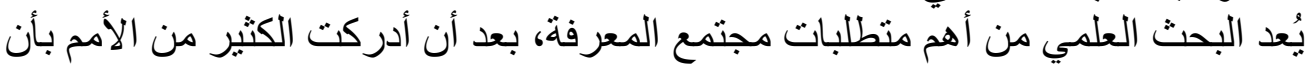

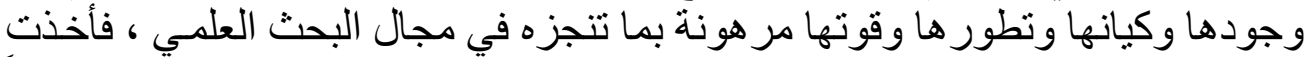

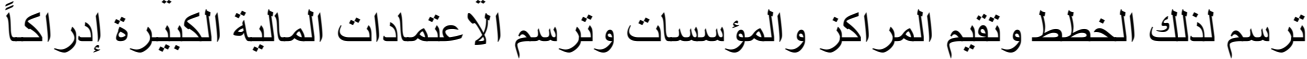

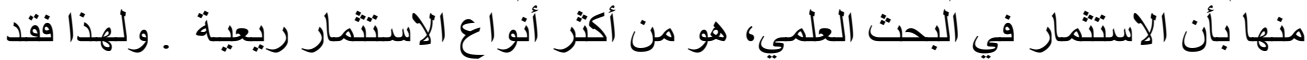

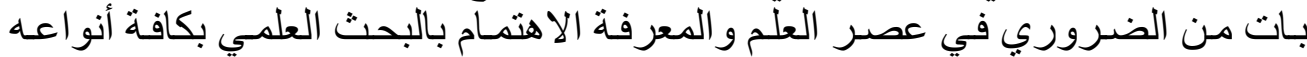

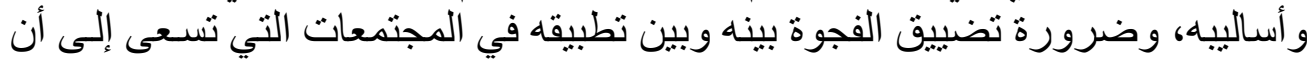

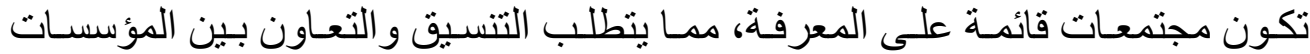

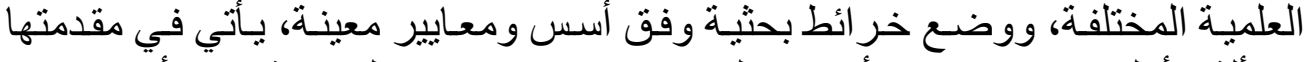

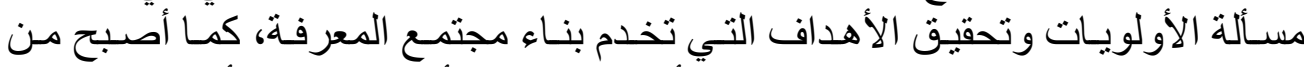

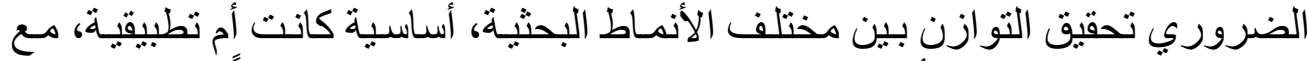

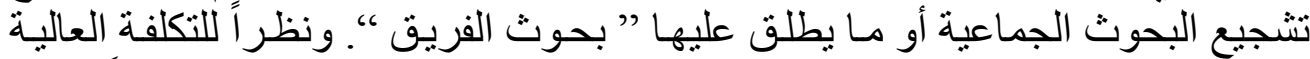

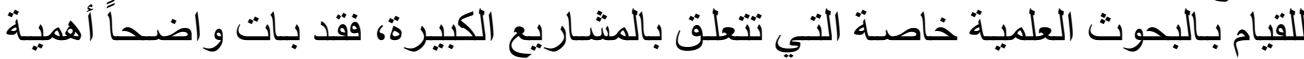

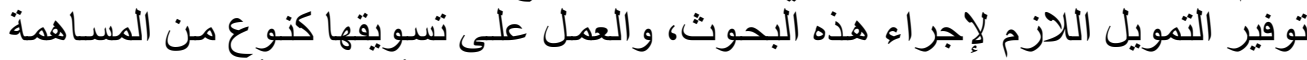

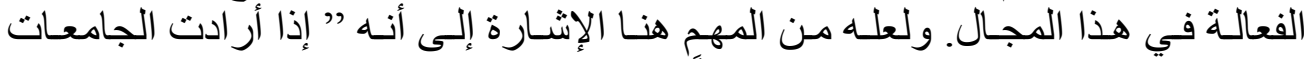

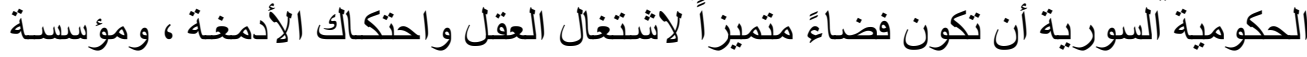

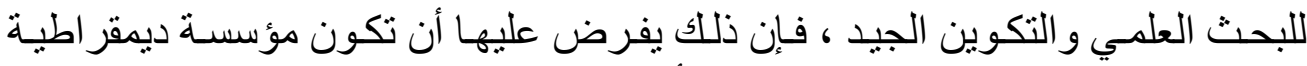

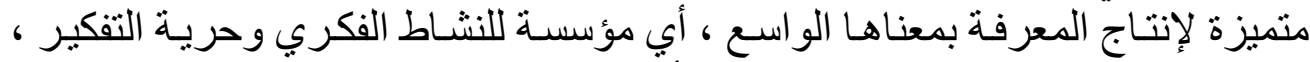

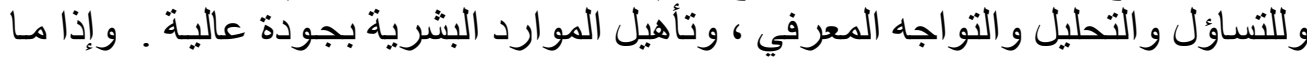

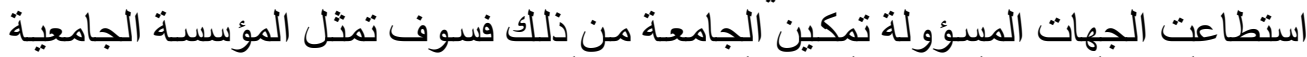

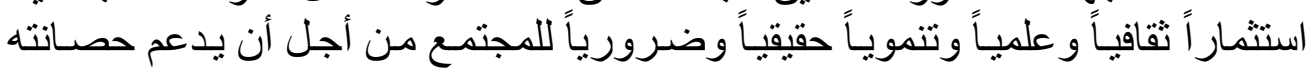

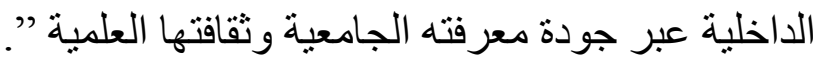
بـ بـ نشر ثقافة التنمية المهنية

بتطلب تطوير المؤسسات التعليمية في مجتمع المعرفة نشر التقافة التي تؤكد على أهمية

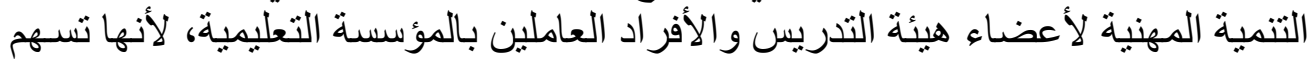

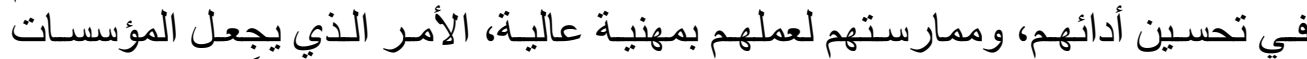

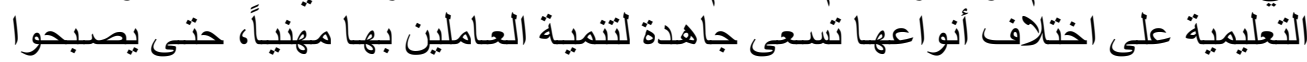

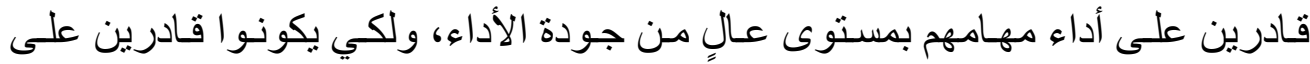

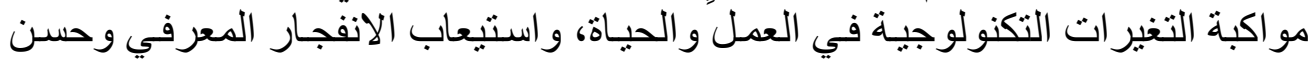




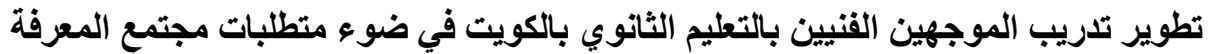

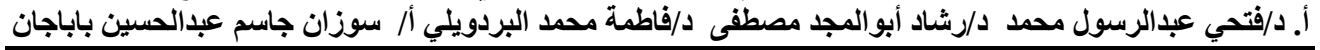

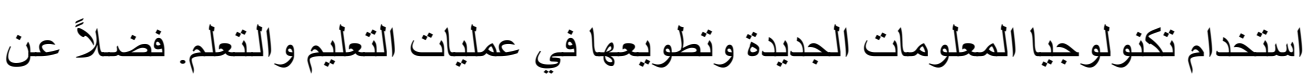

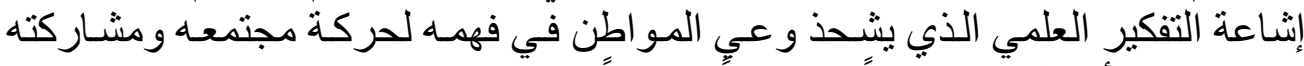

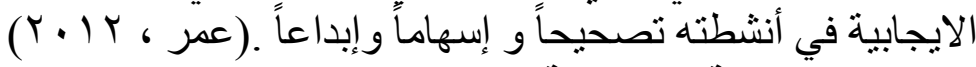

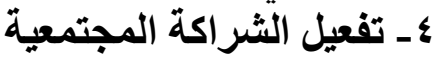

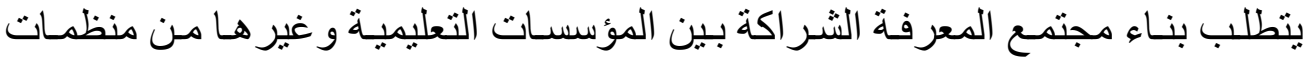

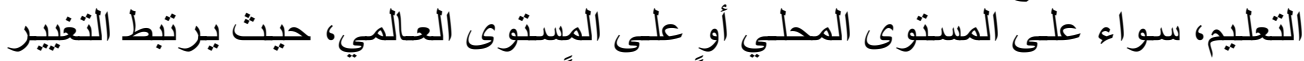

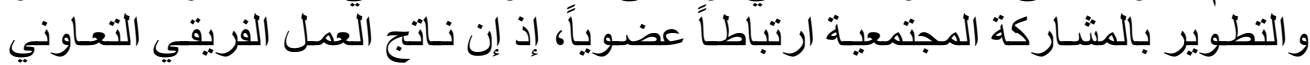

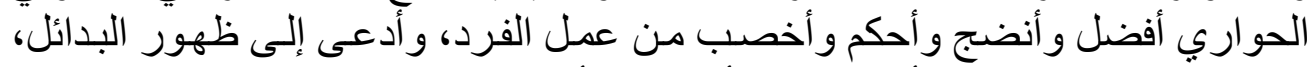

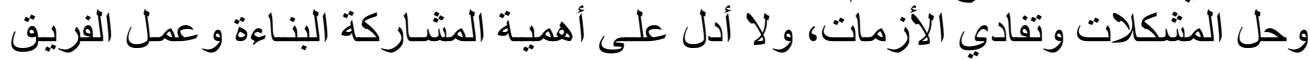

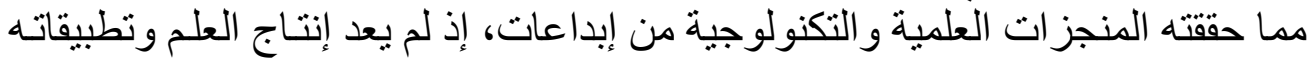

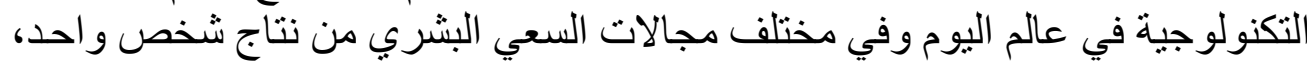

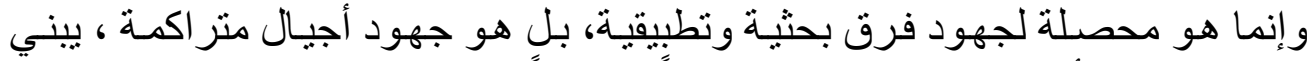

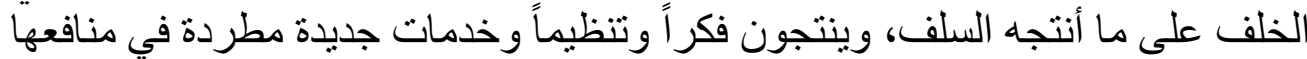

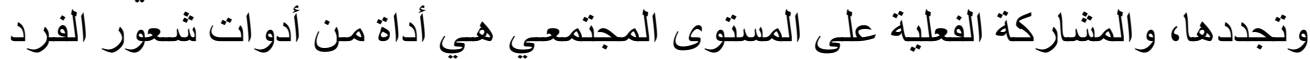

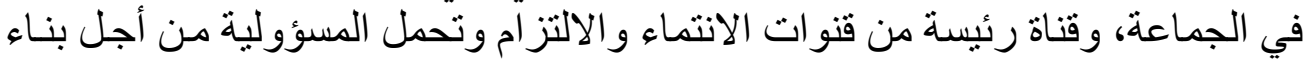

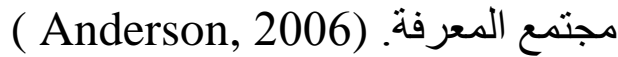

0ـ توفير مصادر بديلة

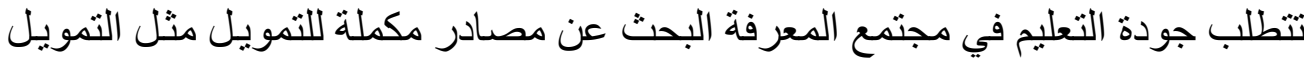

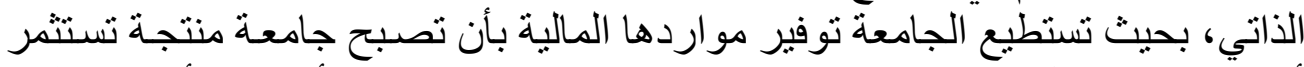

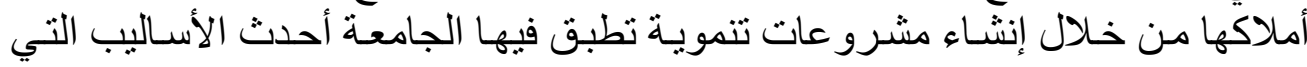

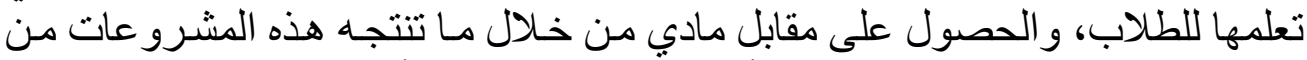

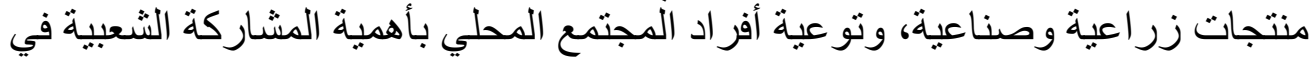

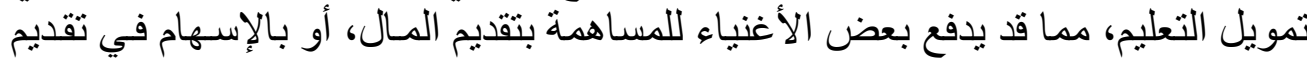

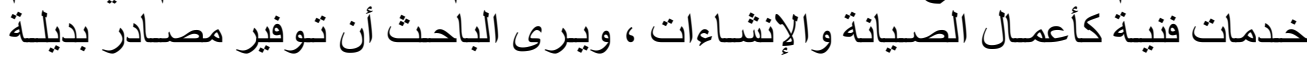

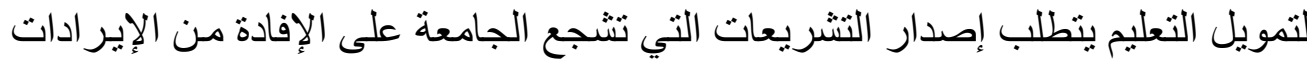

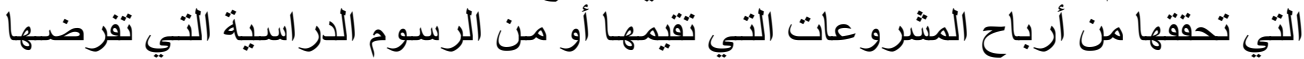

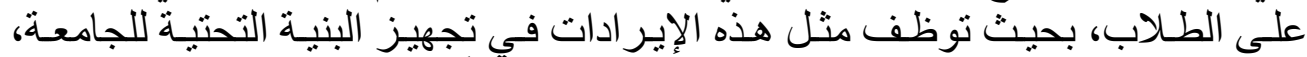

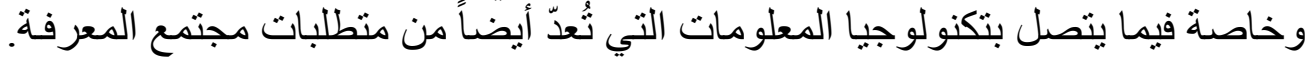

(Y. 17 ، Booth)

\section{צـ التوجه نحو تطبيق الإدارة الرقمية}

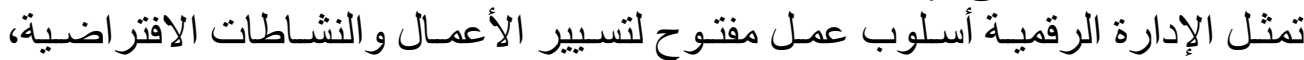

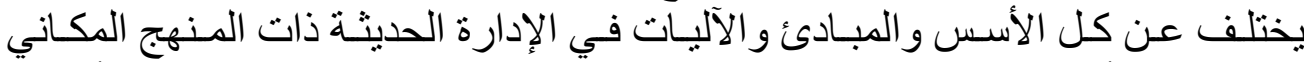

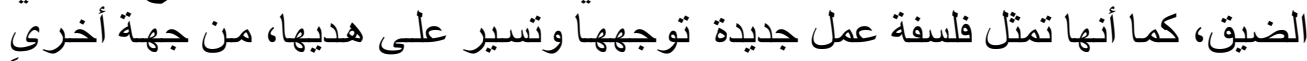

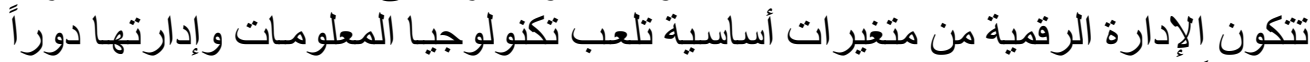

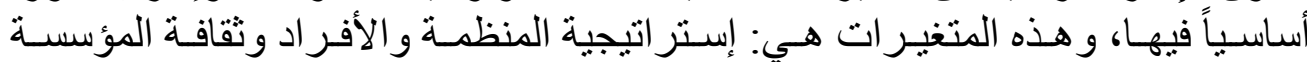

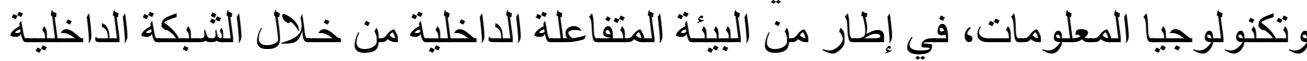




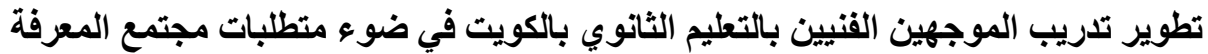

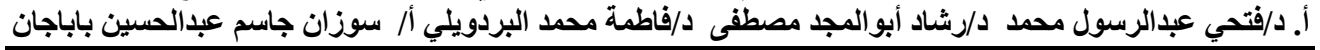

Intranet

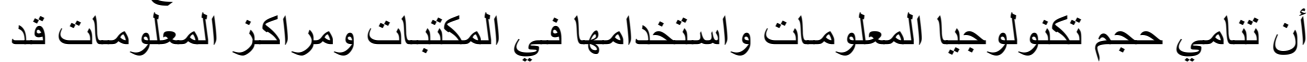

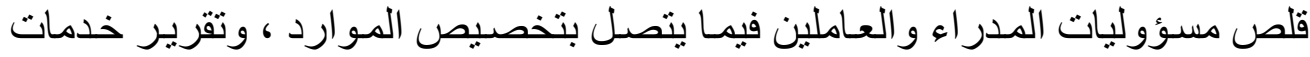

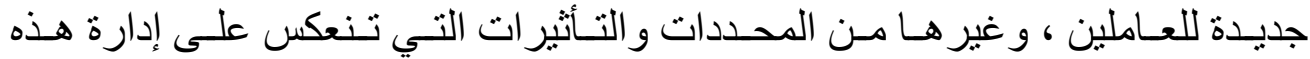

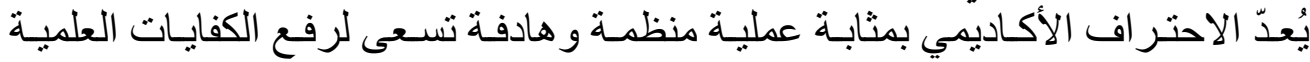

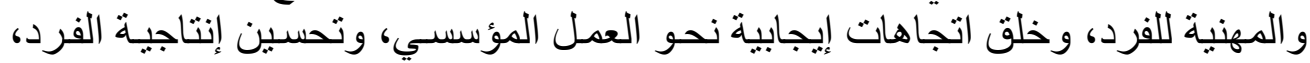

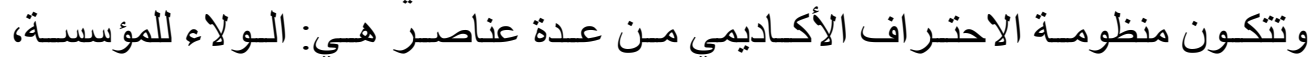

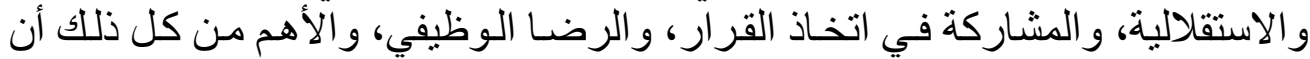

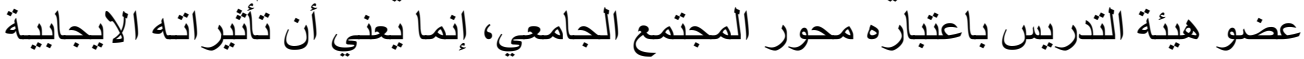

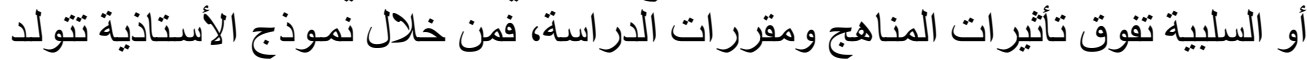

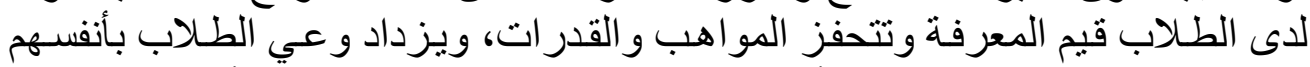

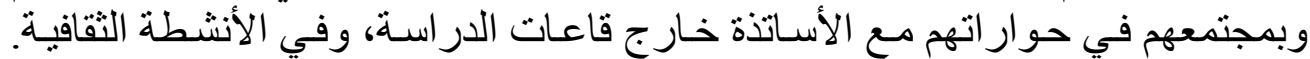

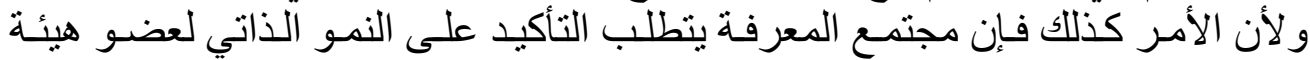
التدريس بالمؤسسة التعليمية من أجل تطوير مهار اته وقدر اته العلمية و المهنية.

Brown)

^ـ التأكيا على إصلاح التعليم

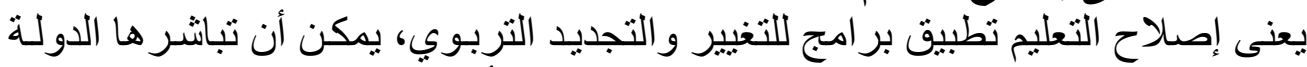

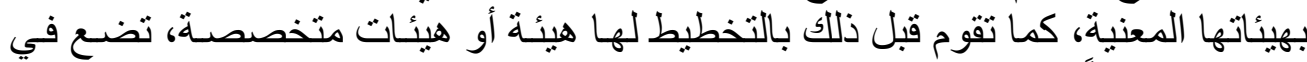

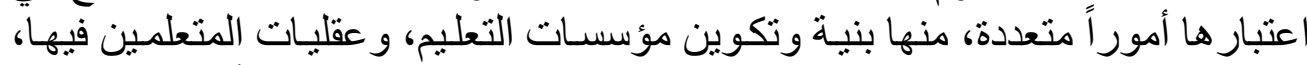

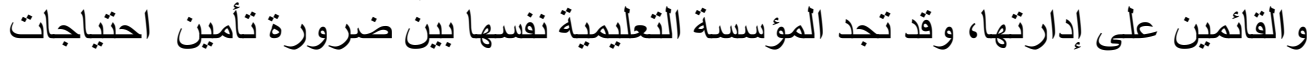

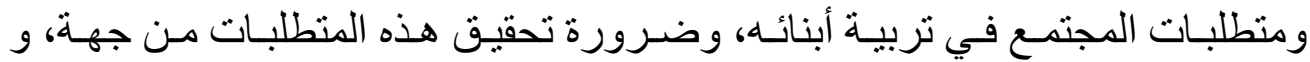

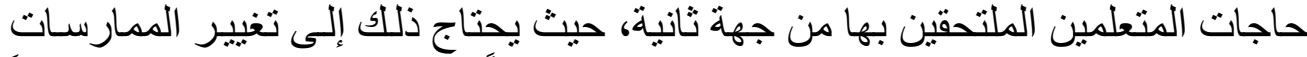

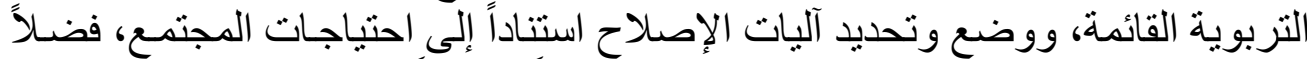

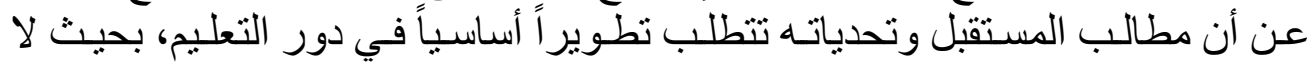
يقتصر على مجرد التكيف و التكييف مع متغير ات الحياة ومو اجهة تحدياتها، لكن الدور التور

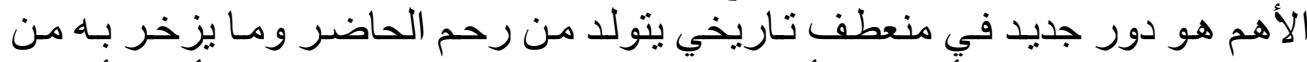

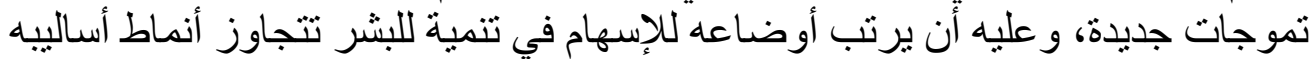

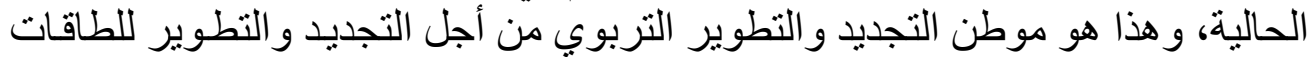

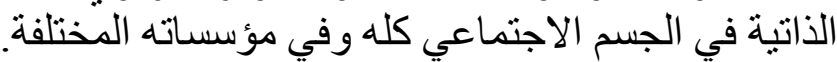
9ـ نشر ثئقافة المعرفة

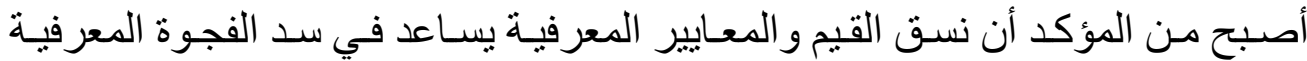

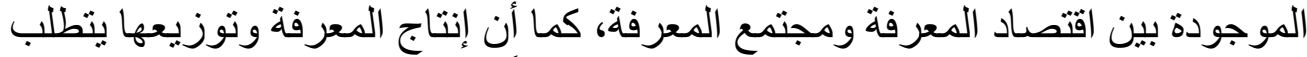

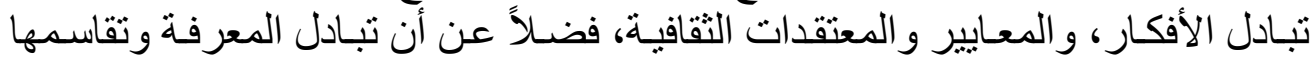

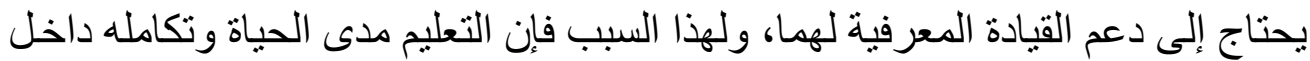




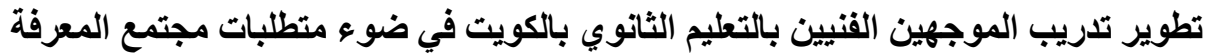
أ. د/فتحي عبدالرسول محمد د/رشاد أبوالمجد مصطفى د/فاطمة محمد البردويلي أ/ سوزان جاسم عبدالحسين باباجان

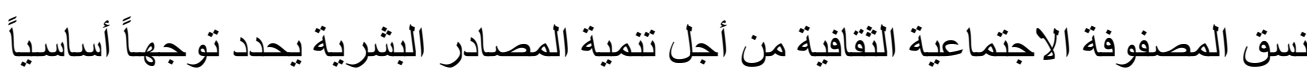

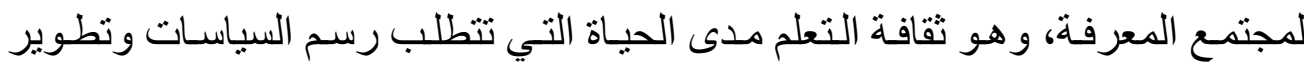

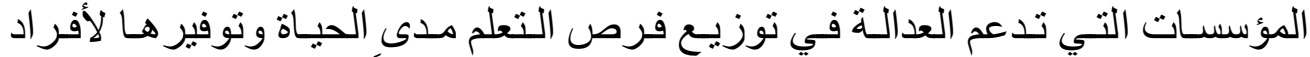

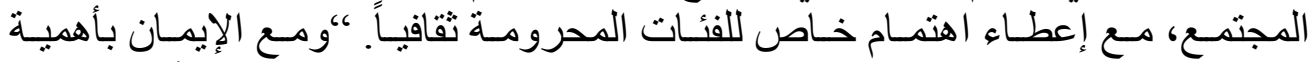

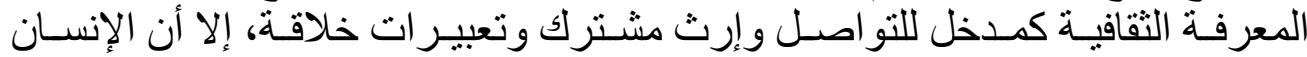

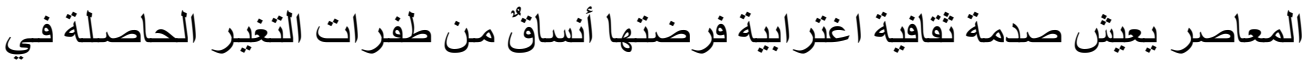

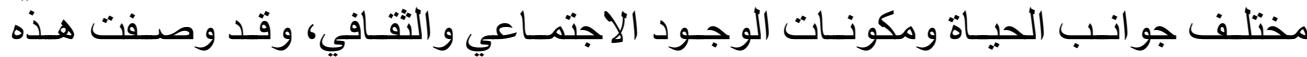

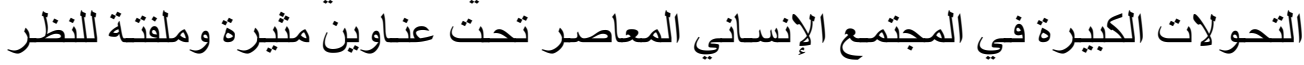

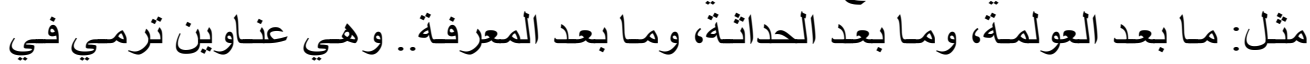

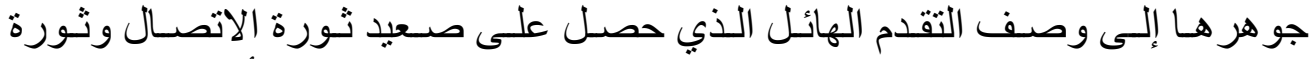
الجينات و الثورة الرقمية وثورة المعرفة .. و غير ها من الثور الثيات التي أثرت على على نمط

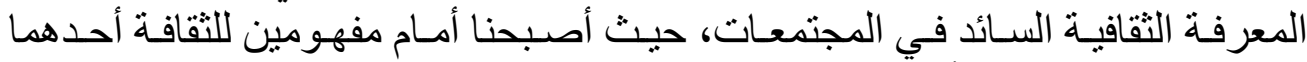

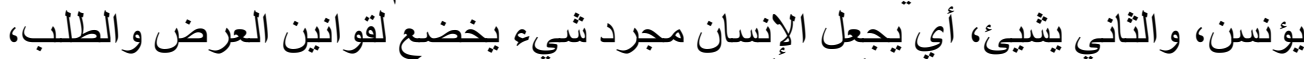

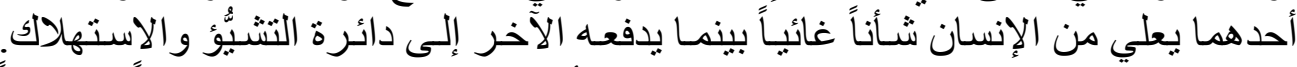

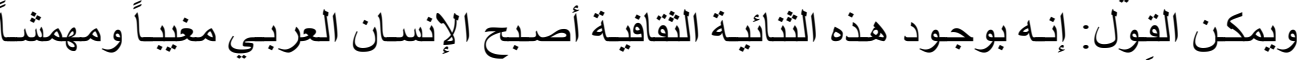

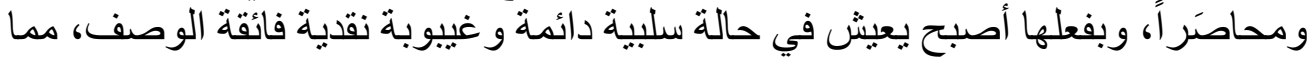

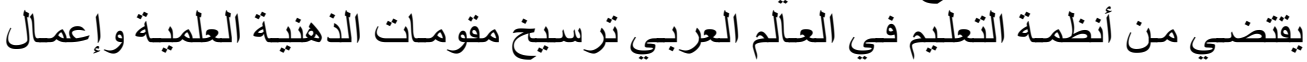

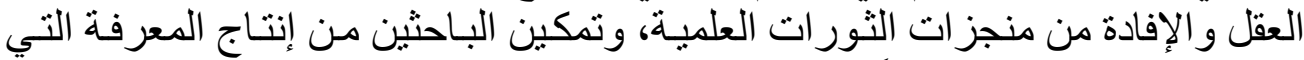

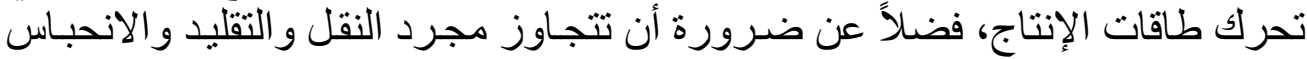

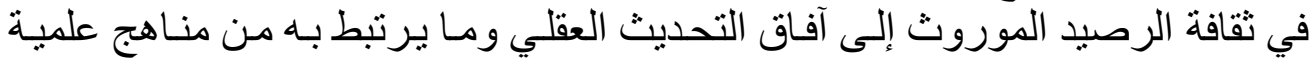
و عقلية متطورة.

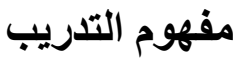

شهدت عملية التدريب التربوي تطوراً كبيراً في العصر الحديث، أسهـم فيه نمو الفكر

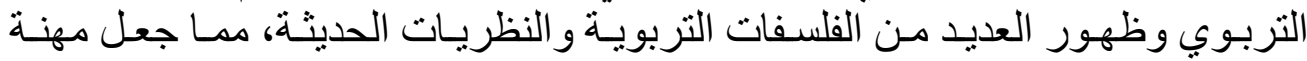

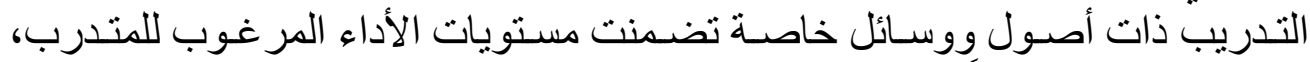

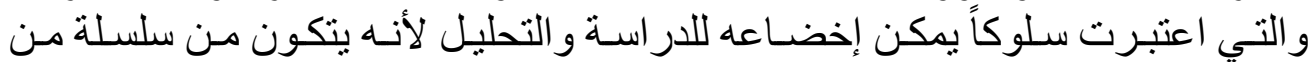

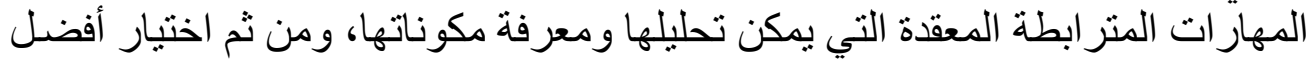

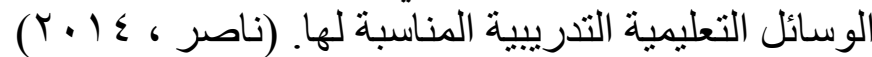

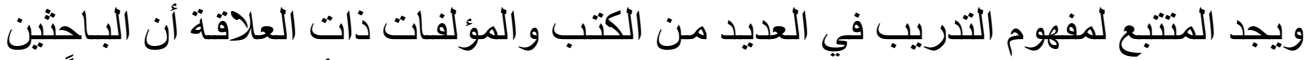

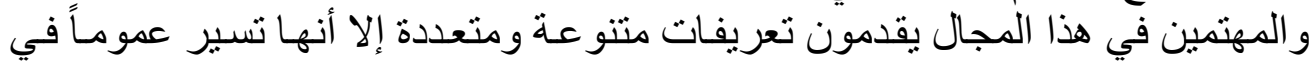

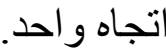

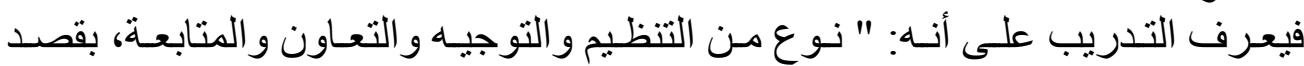

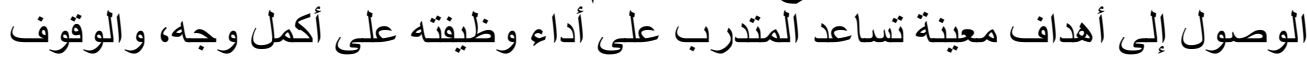

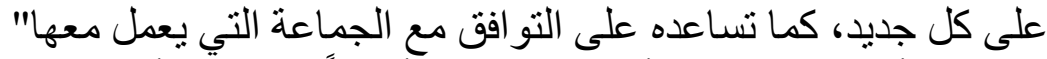
ويعرف بأنه: "مجمو عة الأنشطة الموجهة أساساً لتحسين الأداء التهلئ المهني" 


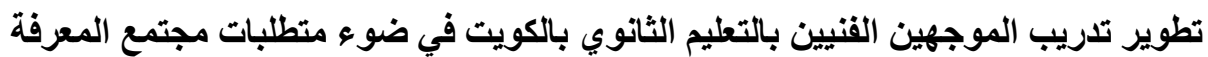

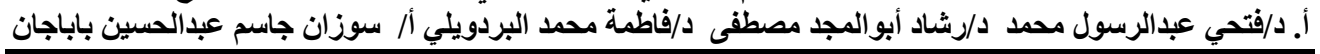

ويعرف التدريب بأنه: " موقف جمعي يتسم بالتغيير والتعديل في نمط التفكير والاتجاه

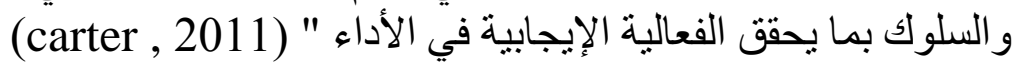

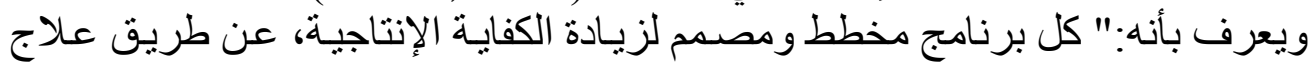

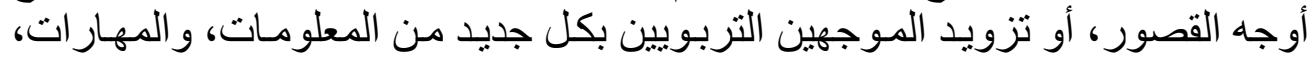

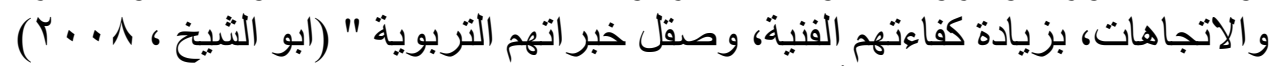

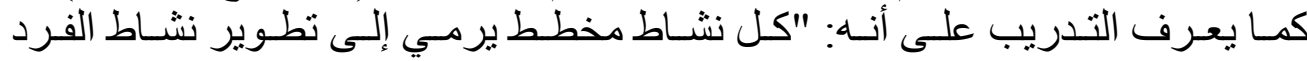

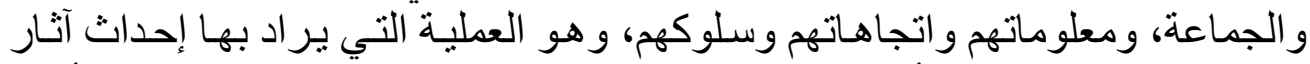

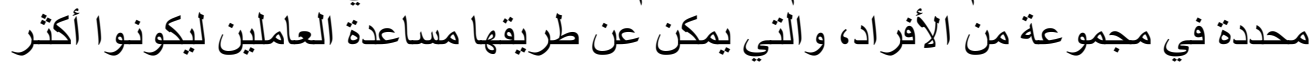

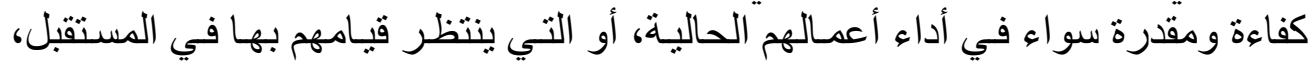

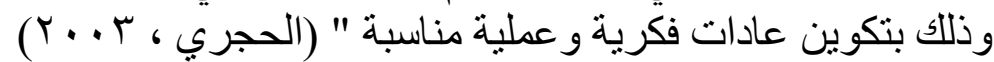

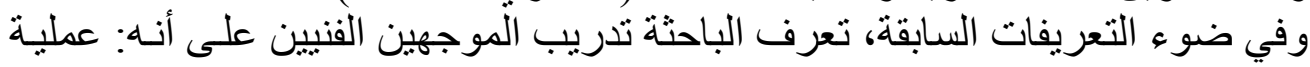

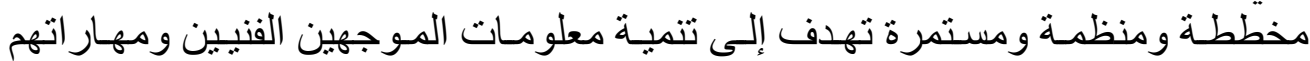

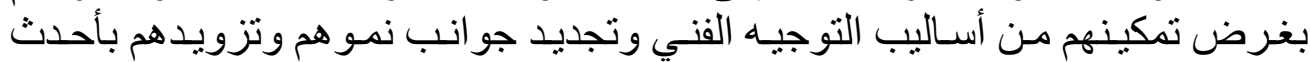

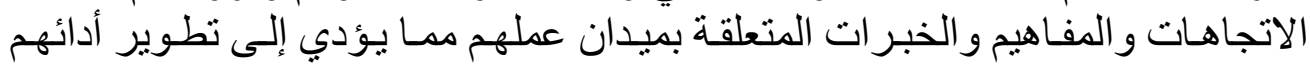
وزيادة إنتاجيتهم.

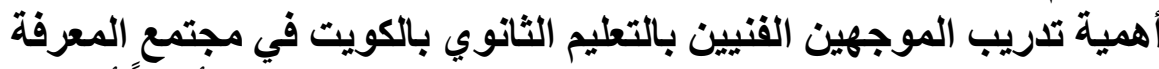

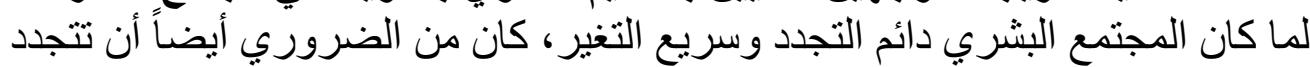

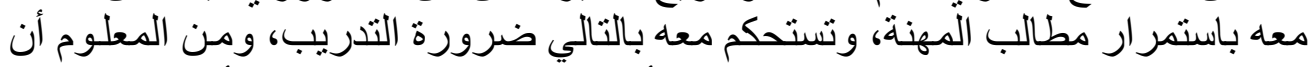

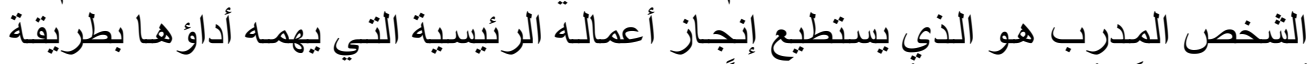

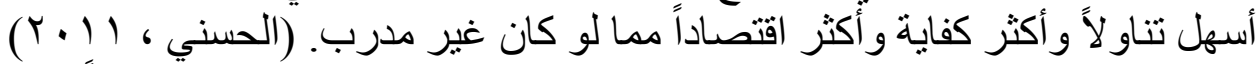

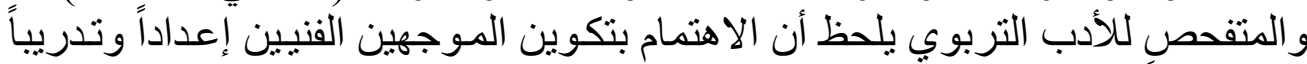

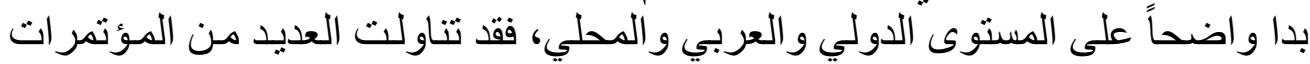

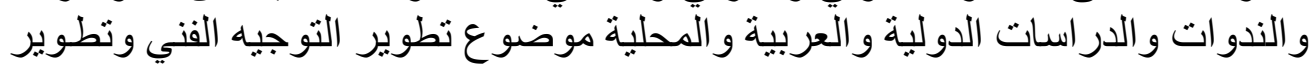

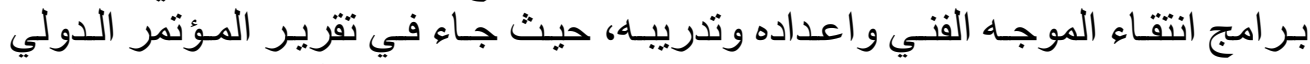

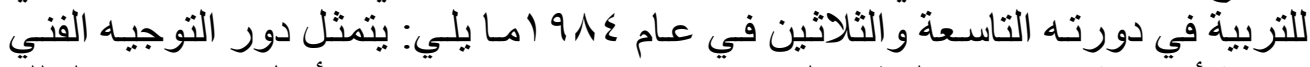

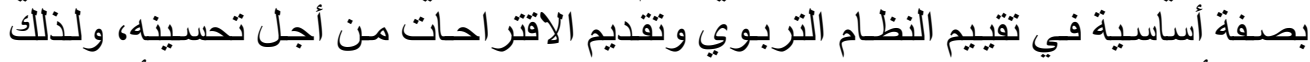

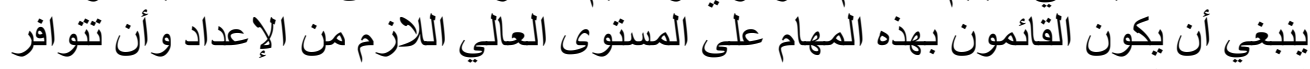

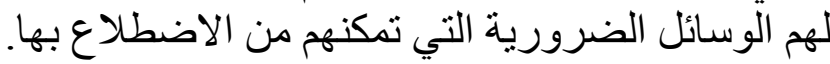

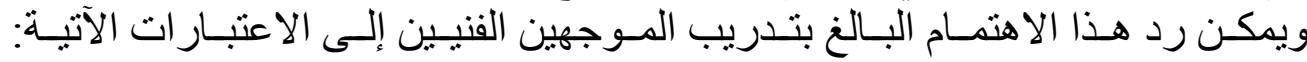

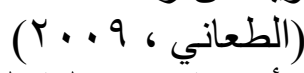

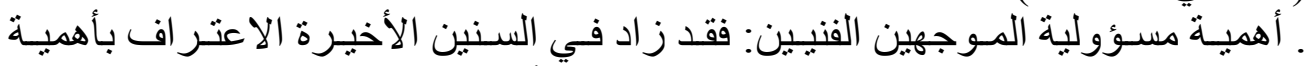

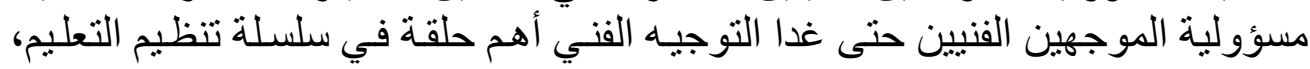

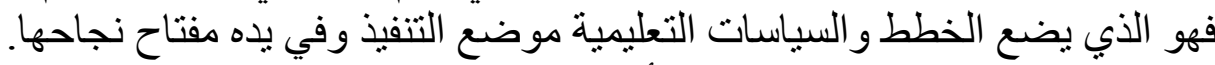

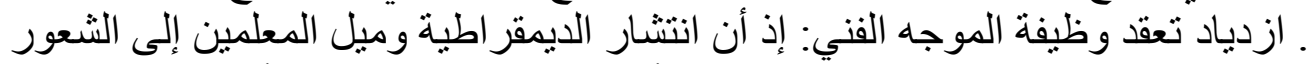

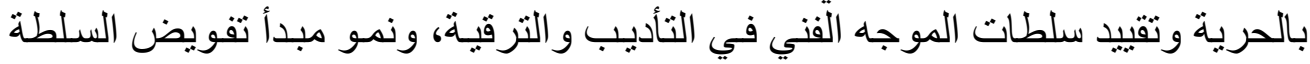




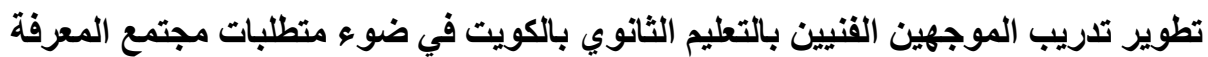
أ. د/فتحي عبدالرسول محمد د/رشاد أبو المجد مصطفى د/فاطمة محمد البردويلي أل/ سوزان جاسم عبدالحسين باباجان

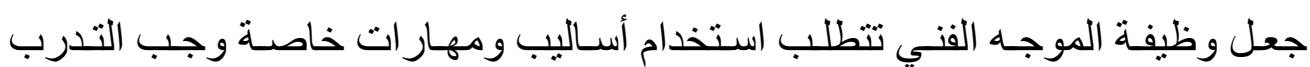
عليها. ـ تدارك سوء الاختيار للموجهين الفنبين: ذلك أن اختيار الموجه الفني لا يعني أنه سوف

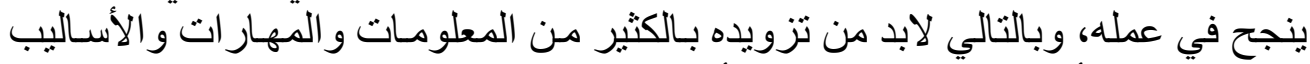

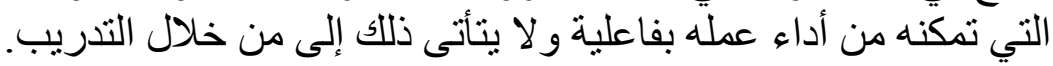

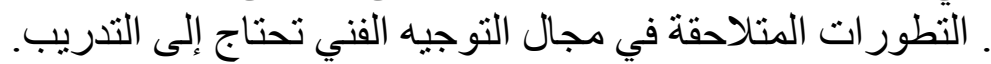

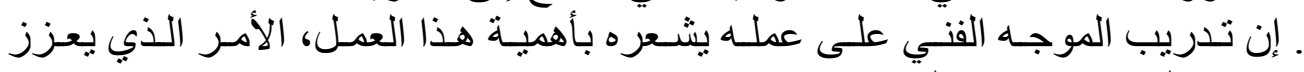

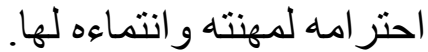

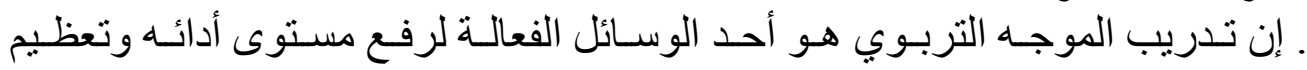

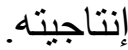

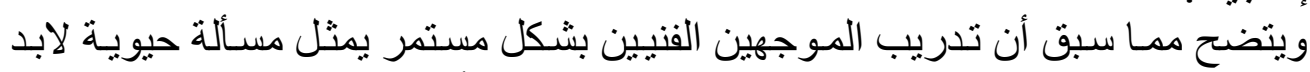

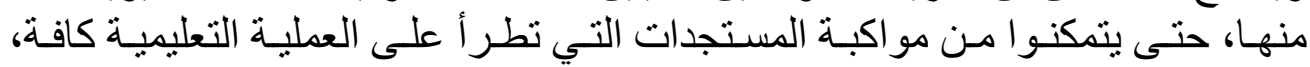

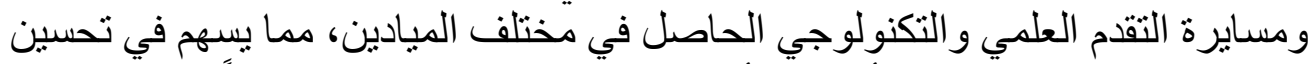

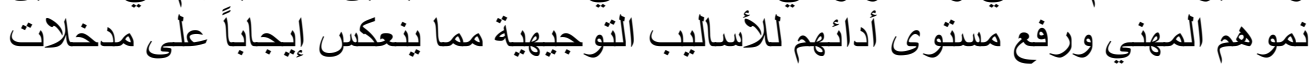
العملية التعليمية كافة.

\section{أهداف تدريب الموجهين الفنيين بالتعليم الثانوي بالكويت في مجتمع المعرفة}

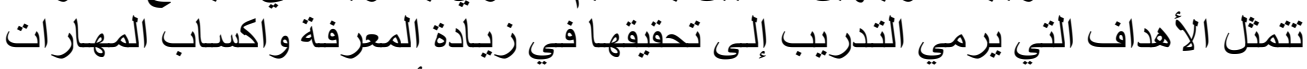

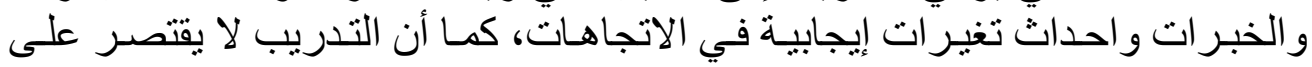

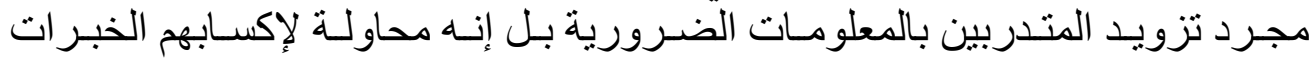

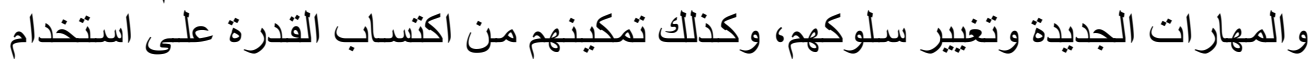

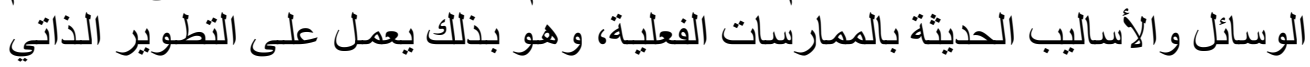

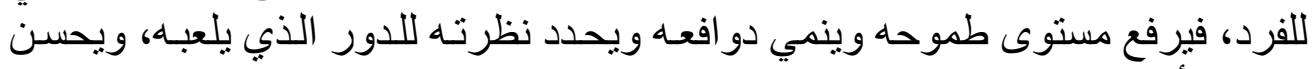
مستوى أدائه. - مئ.

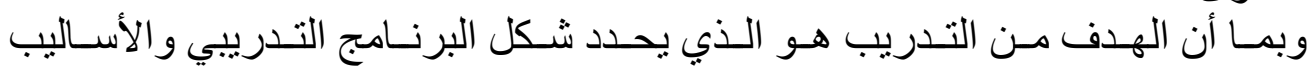

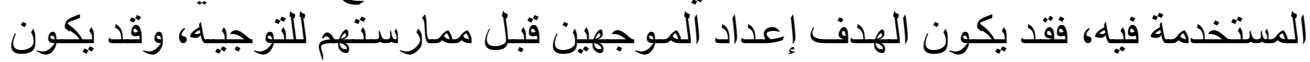

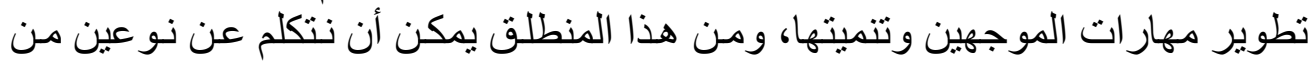

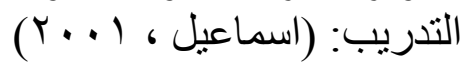

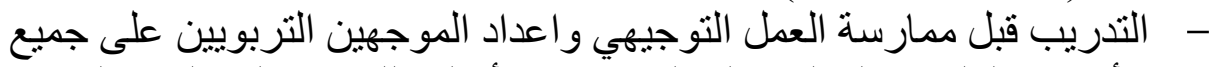

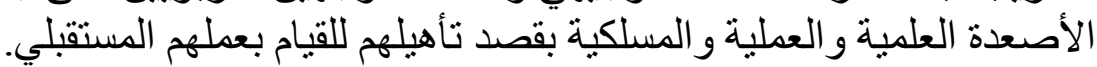

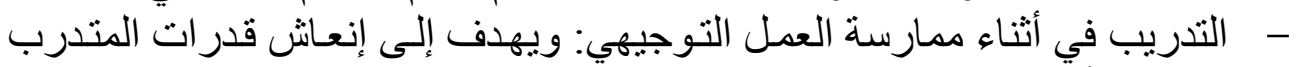

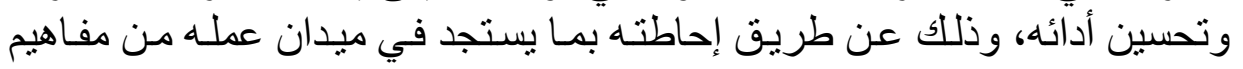

$$
\text { وخبر ات و واتجاهات جديدة. }
$$

ويهتم المفكرون في تدريب الموجهين الفنيين اهتماماً بالغاً لتحقيق الأهداف الآتية بوجـه

. تنمية قدر ات الموجهين الفنيين ورفع كفايتهر.

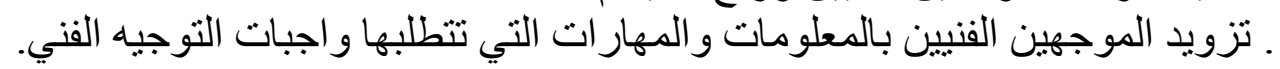




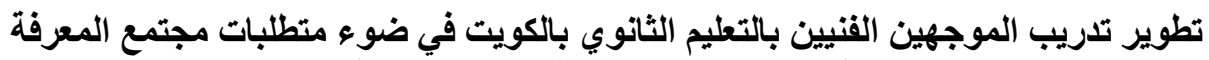

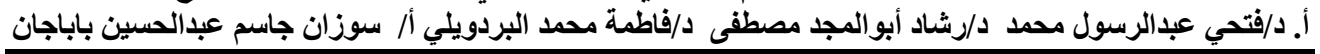

ـ توفير مهار ات التوجيه الفني الأساسية مثل تخطيط العمل و عقد المؤتمر ات والندوات

ومعالجة المشكلات.

. توفير الثعور بالمسؤولية بصورة المثاتية فعالة.

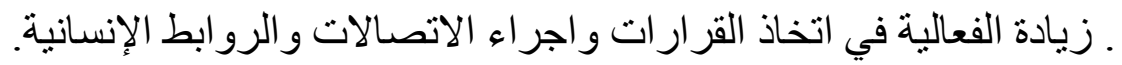

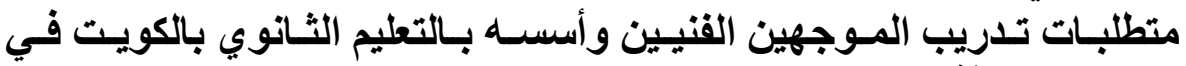

\section{مجتمع المعرفة منئة}

يورد الكثير من الدارسين و الباحثين العديد من المنطلقات و الأسس التي ينبغي مر اعاتها

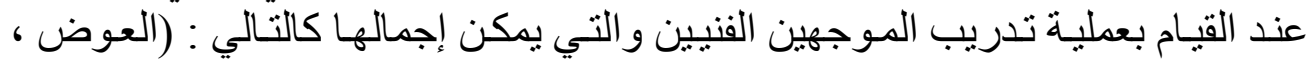

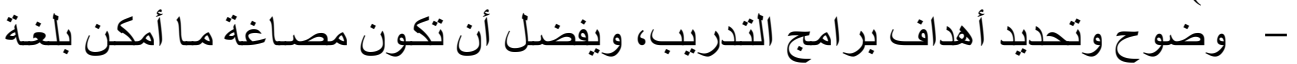

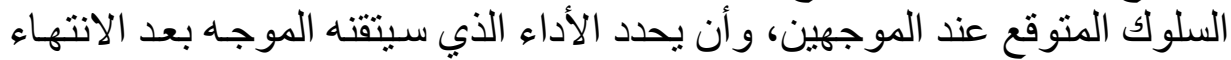

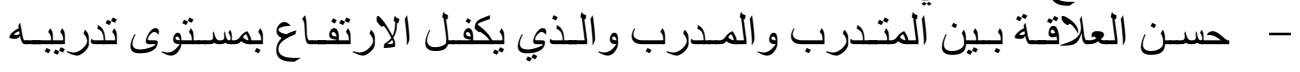
وتحسين و اقعه.

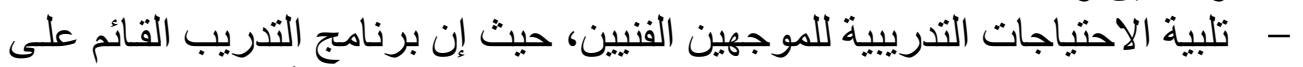

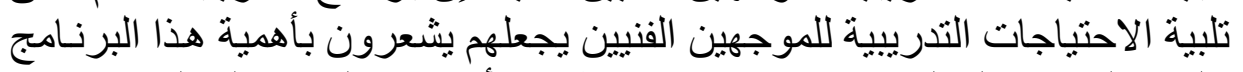

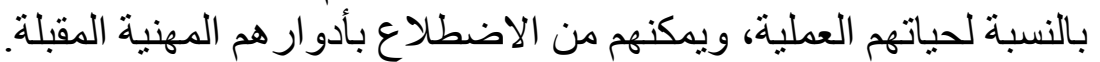

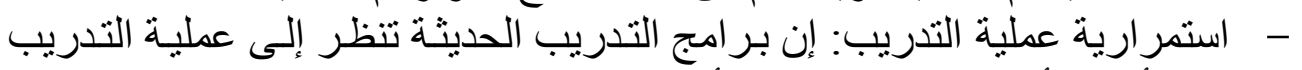

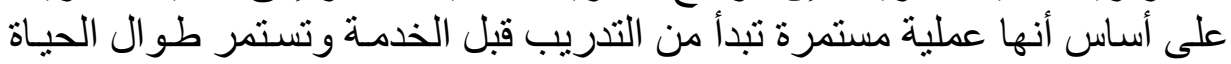

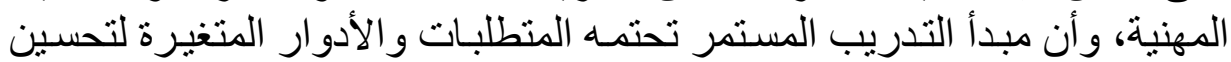

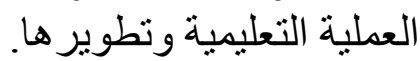

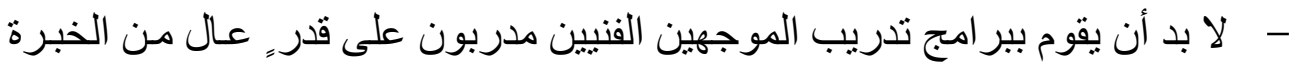

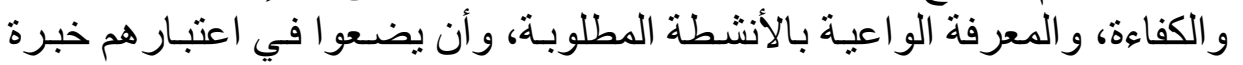

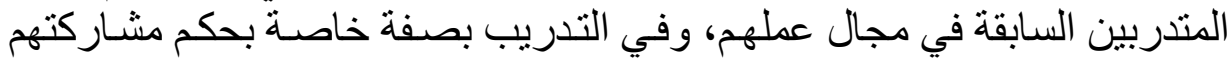
في بر امج سابقة.

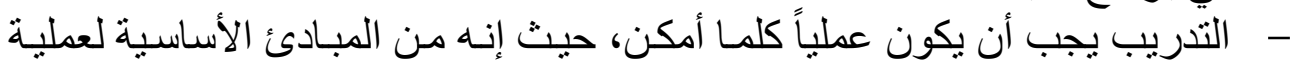

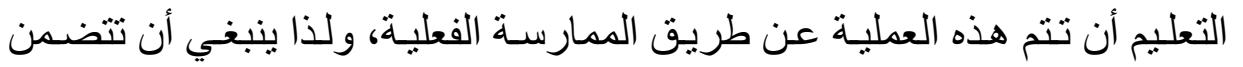

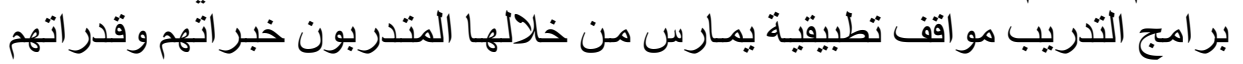

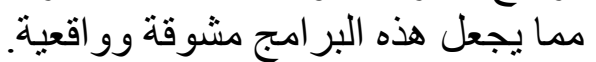

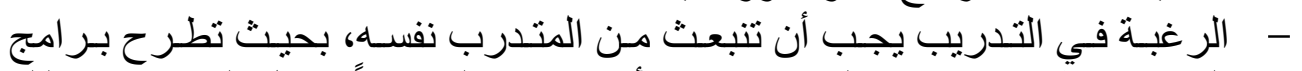

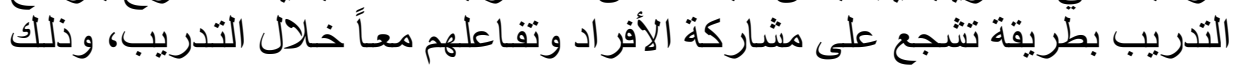

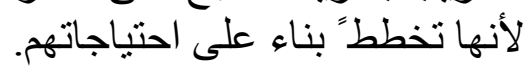

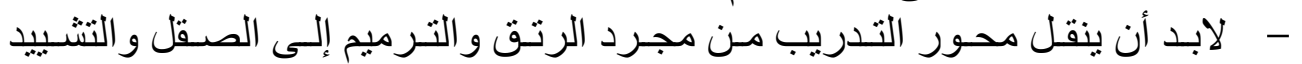
ومسايرة أحدث التطور ات العلمية والتربوية. 


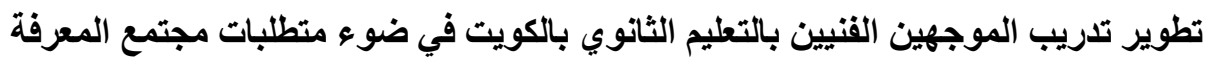

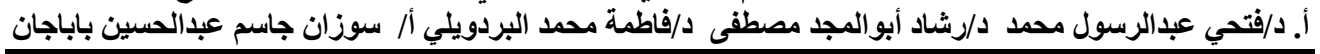

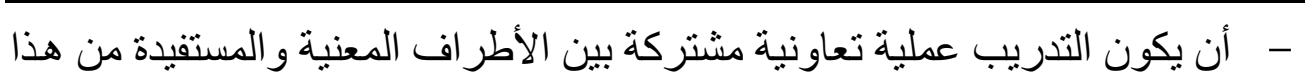

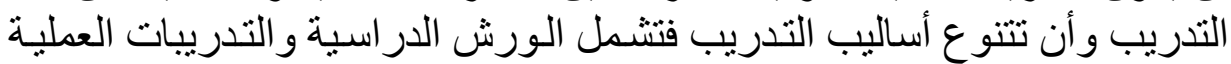
و المناقثات و الدر اسات النظامية و الدر اسات بالمر المر اسلة.

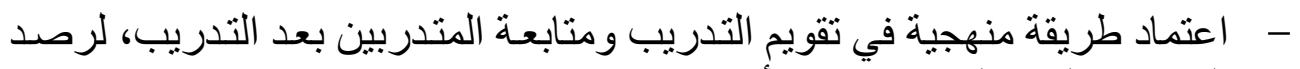

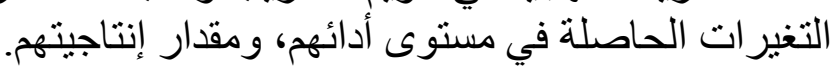

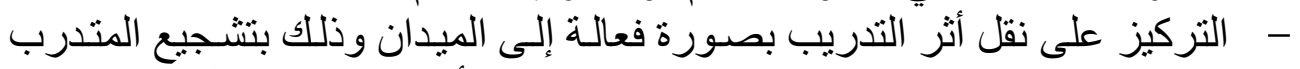

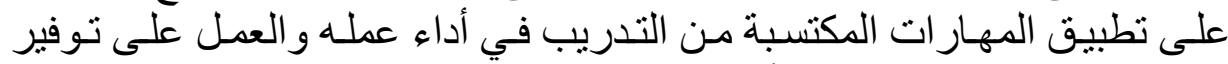

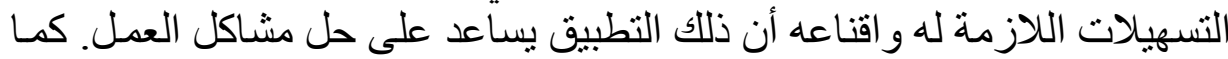

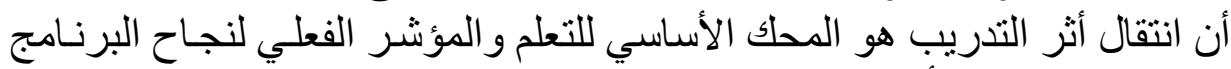
التدريبي في تحقيق أهدافه.

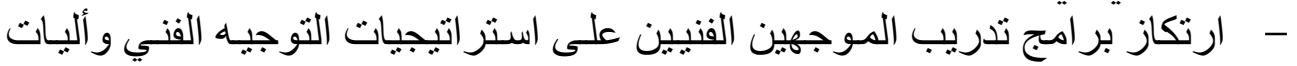

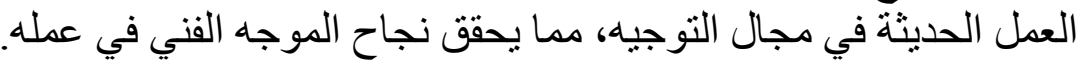

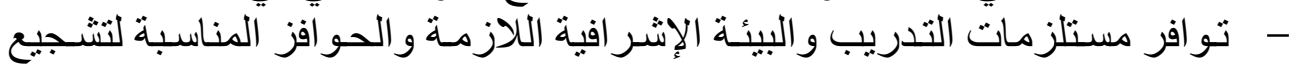
المتدربين على الالتحاق ببر امج التدريب.

\section{الاحتياجات التدريبية للموجهين الفتيين بـالتعليم الثانوي بالكويت في مجتمع}

\section{المعرفة}

تعد الاحتياجـات التدريبيـة الأسـاس الذي يسـاعد النشـاط التدريبي على تحقيق أهدافهـ،

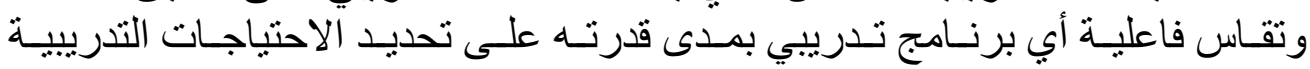

\section{مفهوم الاحتياجات التدريبية:}

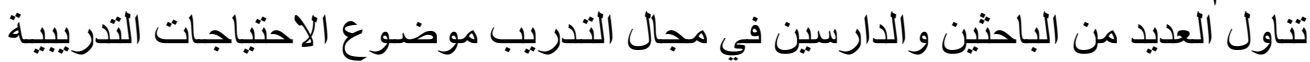

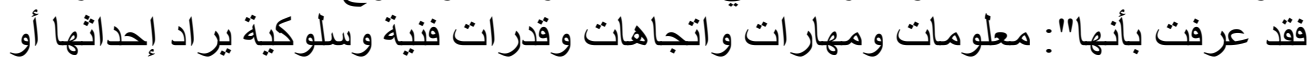

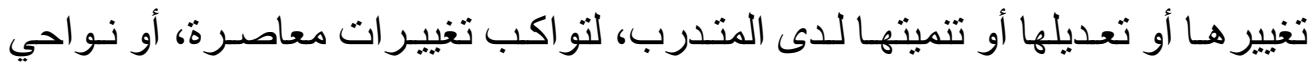
تطويرية" تعير

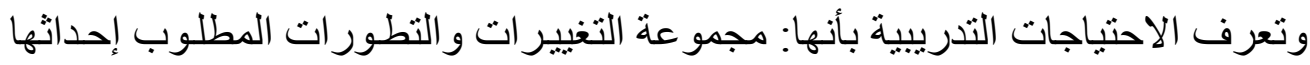

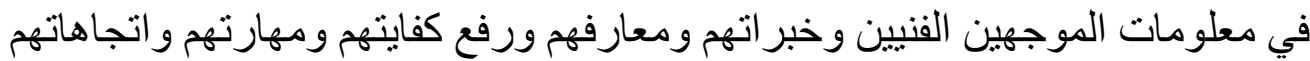

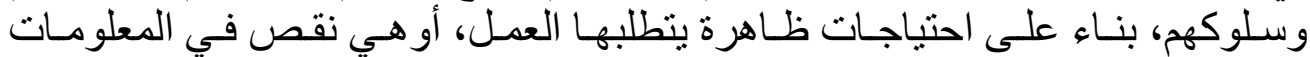

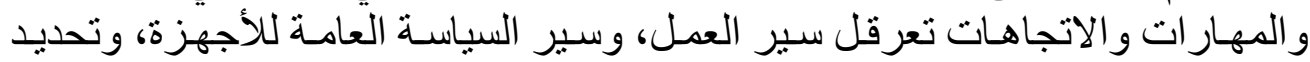

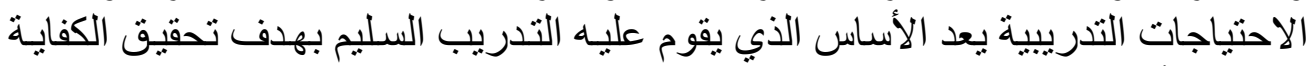

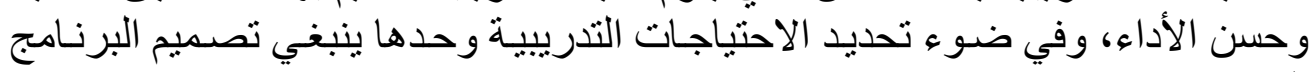
التدريبي.

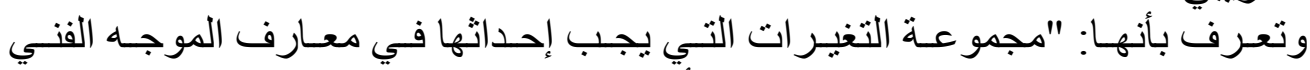

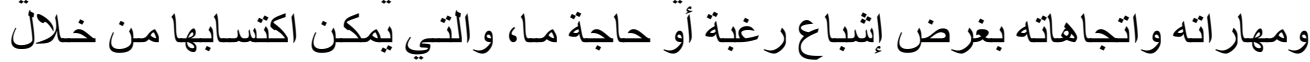

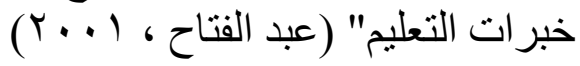




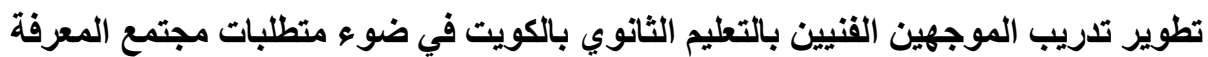

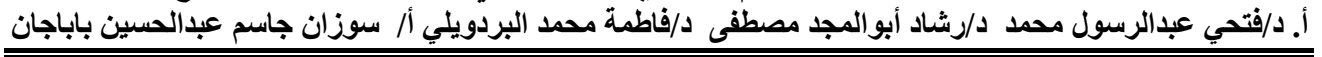

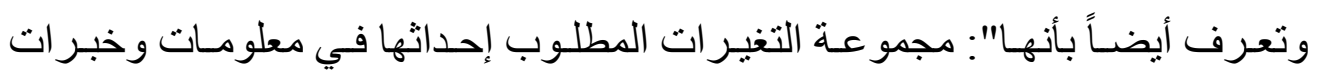

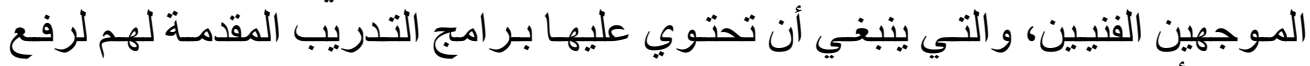

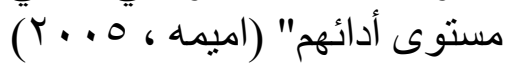

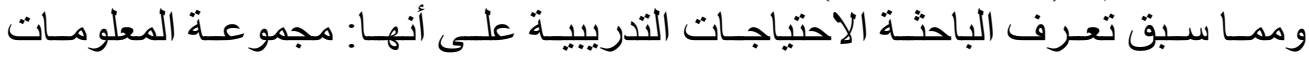

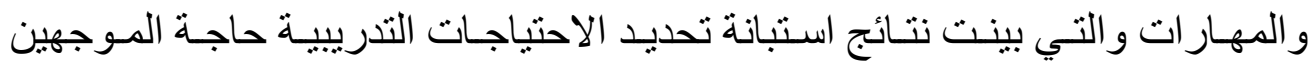

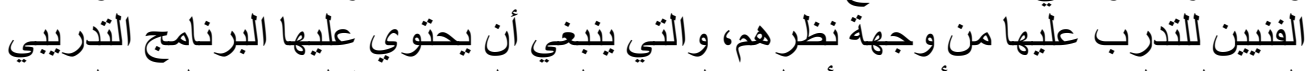

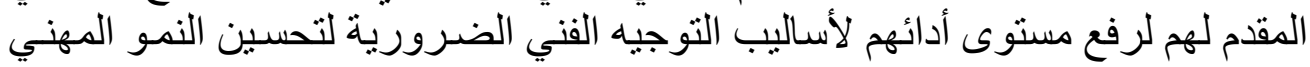
للمعلمين.

أهمية تحديد الاحتياجات التدريبية:

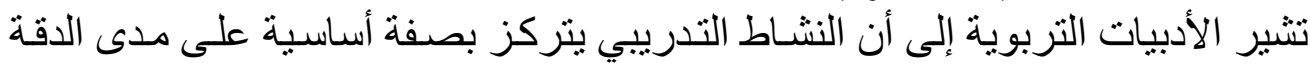

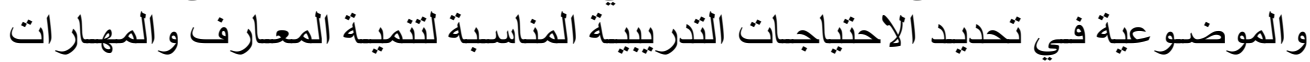

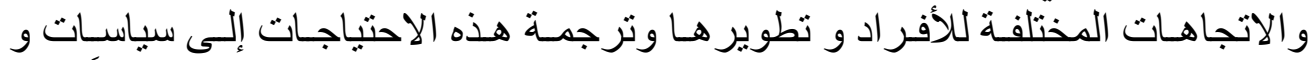

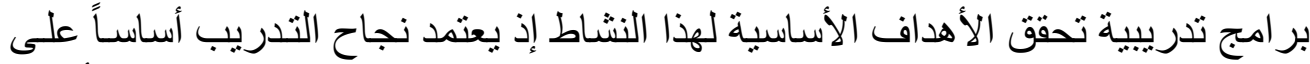

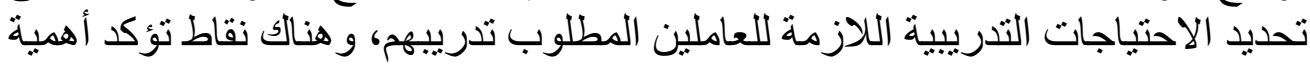

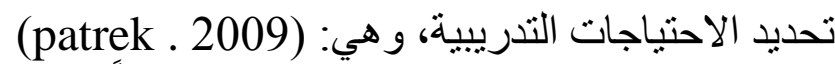

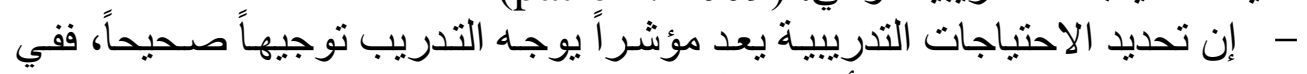

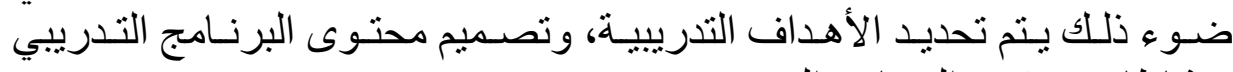
و نشاطاته، وتقويم البرنامج التدرئي.

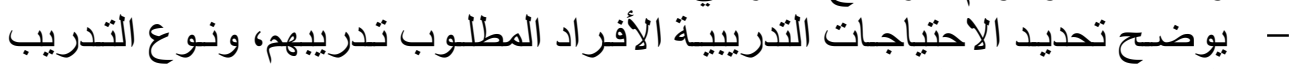

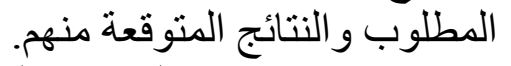

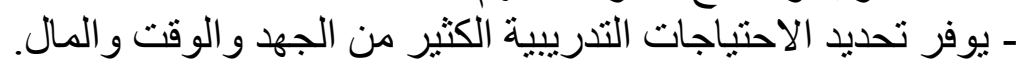

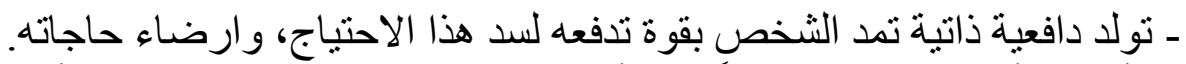

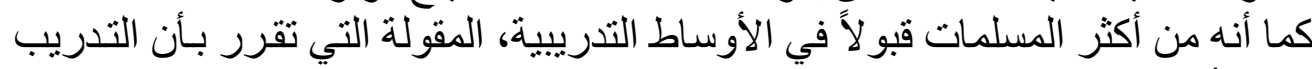

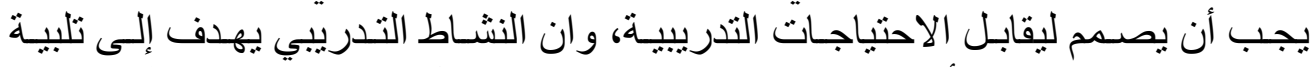

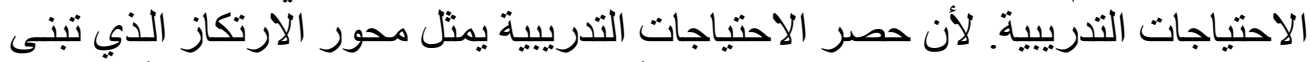

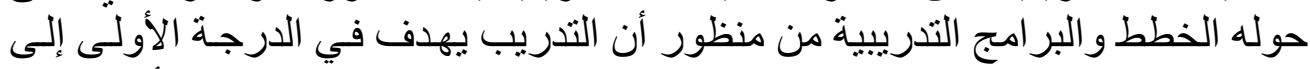

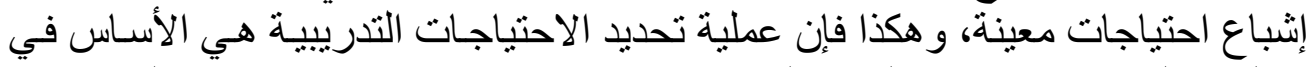

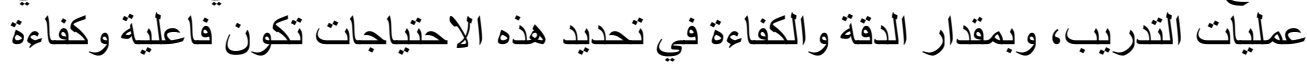

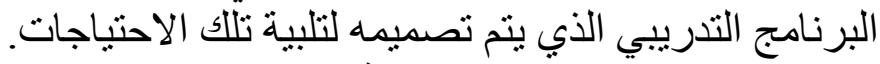

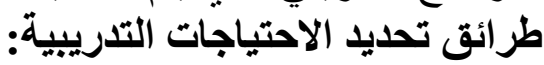

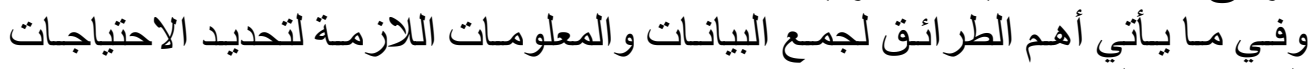

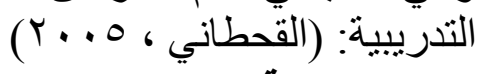

$$
\begin{aligned}
& \text { - الاستبانة: - الإنة: } \\
& \text { - الاختبارات: } \\
& \text { - تقويم الأداء: } \\
& \text { - تحليل المشكلات: }
\end{aligned}
$$




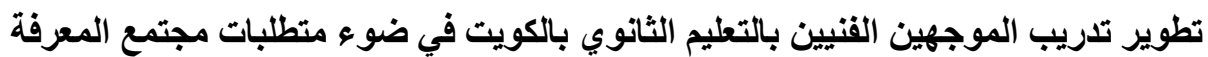

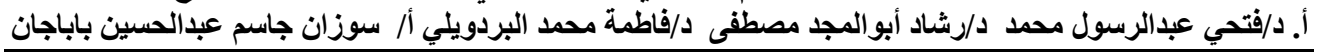

- - آراء الموجهين القنيين:

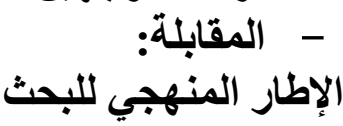

المحور الاول : توليد المعرفة

\begin{tabular}{|c|c|c|c|c|c|c|c|c|}
\hline 雪: & النسبة & المعياري & المتوسط & $Y$ & حد مالي & نعم & العبار ات & r \\
\hline 9 & V & $\cdot, \wedge \wedge$ & r, & N & 09 & IrA & 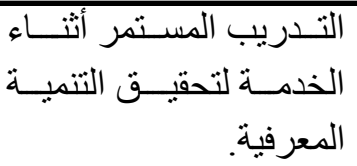 & 1 \\
\hline r & 9. & $\cdot, 77$ & $r, V$ & ro & vo & $1 V$. & الإبداعية. على طرق التفكير & r \\
\hline 0 & $\Lambda T$ & $\cdot, V$ & $r, \leqslant T$ & 17 & $1 \cdot r$ & $10 r$ & 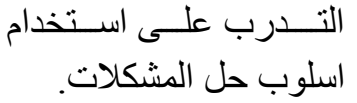 & r \\
\hline$\Lambda$ & س & $\cdot, \vee \vee 9$ & $r, r_{T}$ & r. & $1 \cdot v$ & Trו & 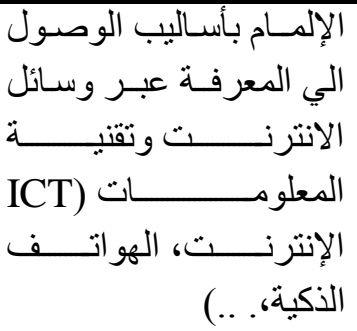 & $\varepsilon$ \\
\hline 1. & $V 1, T V$ & $\cdot, \vee \vee q$ & $r, 10$ & 00 & 94 & Tr & العلمي الإلمـام بمهــار ات التفكيـر & 0 \\
\hline V & va,r & $\cdot, \vee \leqslant \varepsilon$ & $r, r \wedge$ & 00 & 19 & Iry & 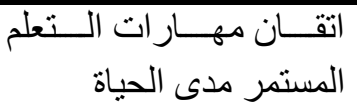 & 7 \\
\hline 7 & $\Lambda \cdot, T V$ & • & $r, \leqslant Y$ & rq & $1 \cdot r$ & $1 \leq r$ & الإلمعـــام بطـــرق ابتكــــار & v \\
\hline 1 & $9 \varepsilon$ & qז, • & $r, \wedge r$ & . & 79 & $r \cdot 1$ & الإلمــام بمهــار ات التفكيـر & $\wedge$ \\
\hline r & $\wedge q, 7 \vee$ & $\cdot, \leqslant 7$ & $r, 7 q$ & ro & 10 & 17. & معرفـــة أســـاليب تنميـــة & 9 \\
\hline$\varepsilon$ & سז, & $\cdot, \vee \leqslant$ & r,o & $\varepsilon r$ & $\vee \cdot$ & 101 & 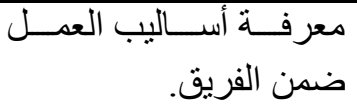 & I \\
\hline 7 & $\Lambda \cdot, T V$ & $\cdot, \mathrm{VT}$ & $r, \Sigma T$ & YT & $1 \cdot r$ & $1 \leq r$ & فوق الإلمــام بمهــار ات التفكيـر & 1 \\
\hline
\end{tabular}




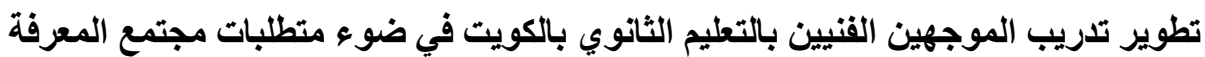

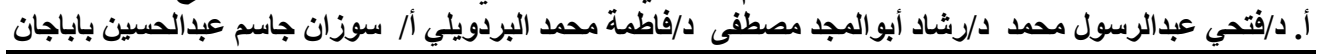

\begin{tabular}{|c|c|c|c|c|c|c|c|c|}
\hline :7: & النسبة & المعياري & المتوسط & $y$ & إلي & نعم & العبار ات & r \\
\hline$\wedge$ & سM, & $\cdot, \vee \vee q$ & r, & $r \cdot$ & $1 \cdot V$ & rTו & 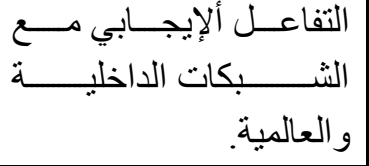 & $\begin{array}{l}1 \\
r\end{array}$ \\
\hline 1 & $9 \leq$ & و מ & $r, \wedge r$ & . & 79 & $r \cdot 1$ & 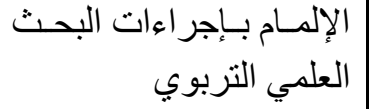 & 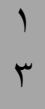 \\
\hline 0 & NT & $\cdot, V$ & $r, \Sigma\rceil$ & 17 & $1 \cdot r$ & $10 r$ & 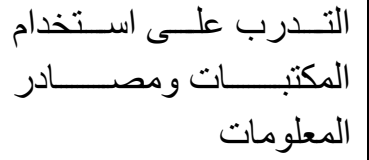 & 1 \\
\hline 9 & V & $\cdot, \wedge \wedge$ & r, & N & 09 & IrA & 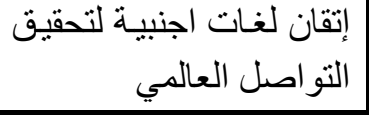 & $\begin{array}{l}1 \\
0\end{array}$ \\
\hline & $\Delta r, \cdot r$ & $\cdot, 7 \wedge \wedge$ & $Y, \Sigma 7$ & $01 Y$ & Irva & rroq & المتوسط العام للبعد ككل & \\
\hline
\end{tabular}

أظهرت نتائج الجدول والذي يوضـح المحور الاول : توليد المعرفة انه مرتفع حيث

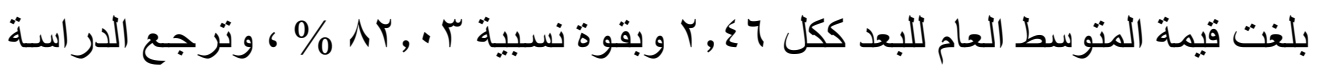

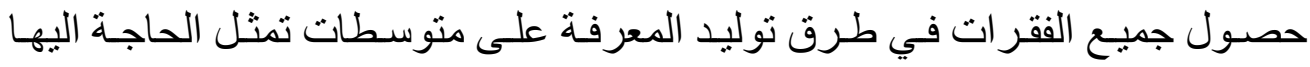

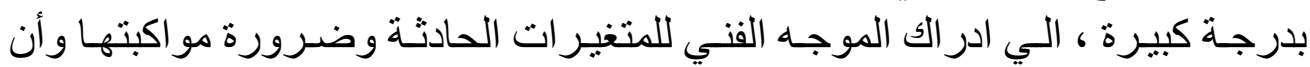

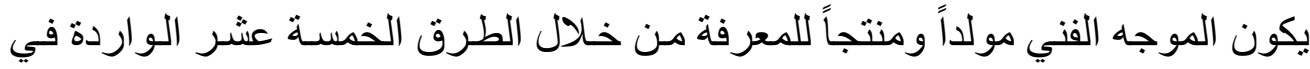

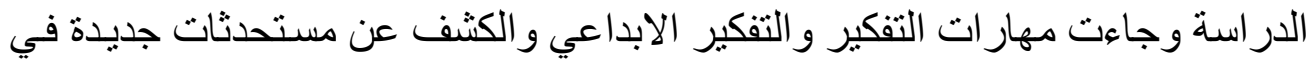
المعرفة في المرتبة الاولى ليؤكد أهمية الدراسة. 


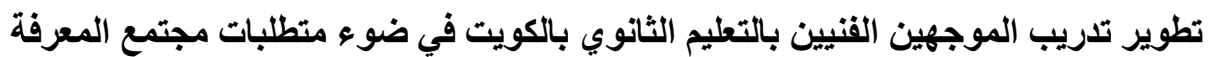

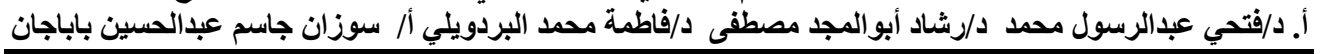

المحور الثاني: نشر المعرفة.

\begin{tabular}{|c|c|c|c|c|c|c|c|c|}
\hline ד. & النسبة & المعياري & سطو & $y$ & إلي & نعم & العبار ات & $\hat{r}$ \\
\hline$\Lambda$ & W & $\cdot, \wedge \wedge$ & $r, r r$ & $r$. & $1 \cdot v$ & r & 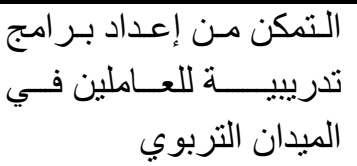 & 1 \\
\hline$r$ & 9 . & $\cdot, 77$ & $r, V$ & 10 & Vo & 11. & 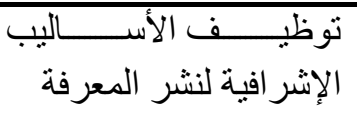 & $r$ \\
\hline$\varepsilon$ & $\Lambda r$ & $\cdot, V$ & $Y, \leqslant Y$ & $\varepsilon r$ & $v$. & 101 & 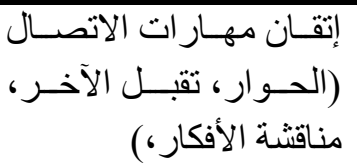 & $r$ \\
\hline V & V०, r & $\cdot, \vee q$ & $Y, Y q$ & 00 & $\vee 9$ & $1 \% q$ & 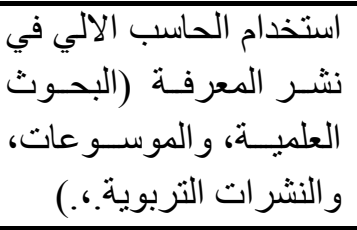 & $\varepsilon$ \\
\hline 9 & VI, TV & $\cdot, \vee q$ & $r, 10$ & $\Lambda \mu$ & 09 & IY & 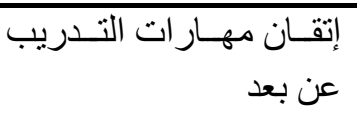 & 0 \\
\hline 7 & vq,r & $\cdot, V \varepsilon$ & $r, \mu \wedge$ & 11 & 1.7 & $1 \leq 7$ & لنشر محتوى معرفي الوسـائط ط المتعـددة & 7 \\
\hline 0 & $\Lambda \cdot, 7 V$ & $\cdot, V r$ & $r, \varepsilon r$ & 1. & $1 \cdot 1$ & lor & 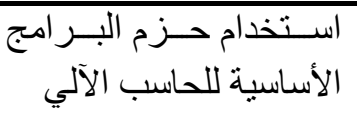 & V \\
\hline$\Lambda$ & W & $\cdot, \wedge 9$ & $r, Y r$ & r. & $1 \cdot v$ & rr & 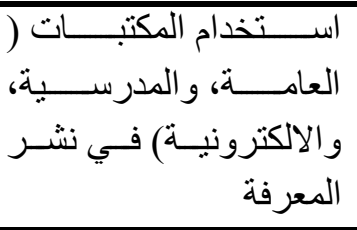 & $\Lambda$ \\
\hline$r$ & $\Lambda \bullet, \mu r$ & $\cdot, V r$ & $Y, \Delta Y$ & ro & ^o & 17. & 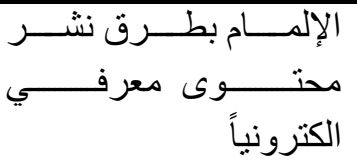 & 9 \\
\hline 1 & r & $\cdot, 71$ & $r, V_{1}$ & - & Tr & $r \cdot \Lambda$ & 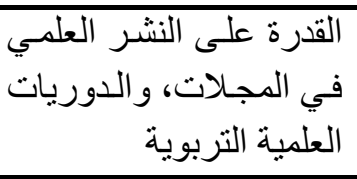 & $\begin{array}{l}1 \\
.\end{array}$ \\
\hline & سז, • & $\cdot$, vor & $r, \varepsilon)$ & $r \cdot \Lambda$ & $\wedge \circ \wedge$ & lore & المتوسط العام للبعد ككل & \\
\hline
\end{tabular}

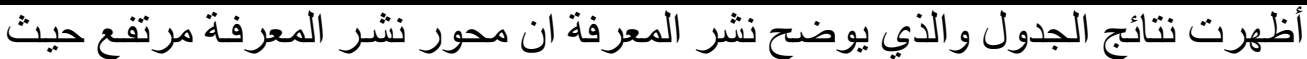

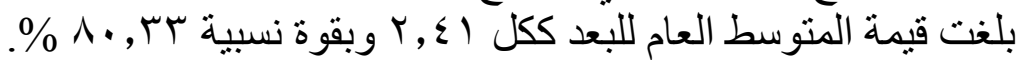




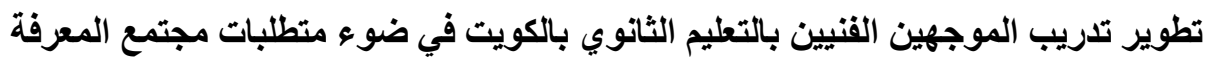

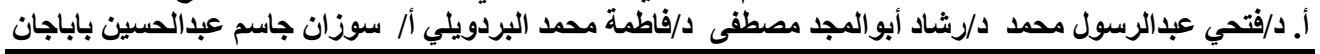

المحور الثالث: توظيف المعرفة في مجال التوجيه القني

\begin{tabular}{|c|c|c|c|c|c|c|c|c|}
\hline 雪: & النسبة & المعياري & المتوسط & ע & حد ما إلي & نعم & العبار ات & r \\
\hline$\varepsilon$ & $\wedge 7,7 \vee$ & $\cdot, 7 V$ & $r, T$ & $\varepsilon r$ & $\vee \cdot$ & 101 & التإلمام بطرق تصميم & 1 \\
\hline$r$ & 94 & $\cdot, \varepsilon r$ & $r, \vee q$ & 1. & $\vee \cdot$ & 19. & الإلمديثة المعتمدة على التدريس تنمية & $r$ \\
\hline 0 & $\wedge 1,7 V$ & $\cdot, V Y$ & $r, \leqslant 0$ & 1. & $1 \cdot 1$ & $10 r$ & 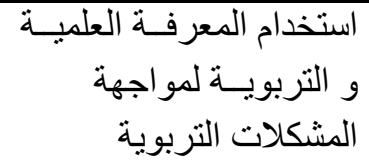 & r \\
\hline 0 & $\wedge 1,7 \vee$ & $\cdot, 77$ & $r, \leq 0$ & 1. & $1 \cdot 1$ & $10 r$ & 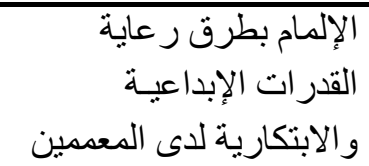 & $\varepsilon$ \\
\hline 1 & 90 & • & Y,^० & . & 7. & YI. & 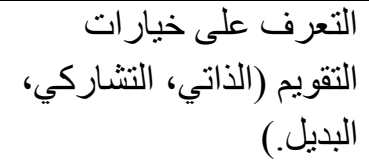 & 0 \\
\hline 7 & מr, & •,Ar & $Y, I V$ & 11 & 1.7 & $1 \leq 7$ & 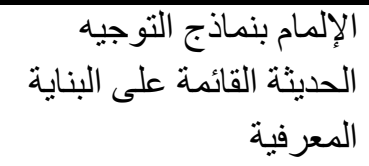 & 7 \\
\hline r & سח, & $\cdot, \leqslant V$ & $r, \Upsilon \wedge$ & ro & 70 & $1 \wedge$. & 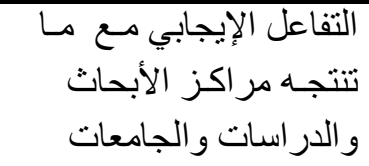 & $V$ \\
\hline r & سז,A & $\cdot, \leqslant \vee$ & $r, 7 \wedge$ & ro & 70 & $1 \wedge$. & 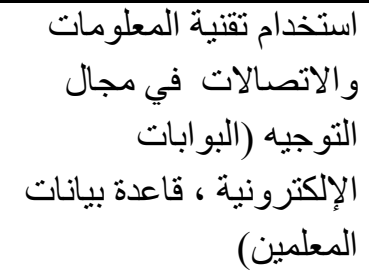 & $\wedge$ \\
\hline$\varepsilon$ & $\wedge 7,7 \vee$ & $\cdot, 7 V$ & $r, T$ & $\varepsilon r$ & V. & 101 & 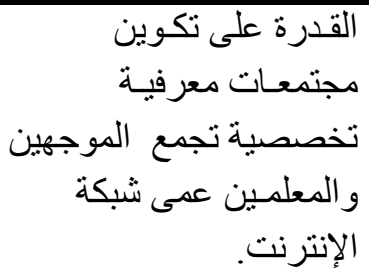 & 9 \\
\hline
\end{tabular}




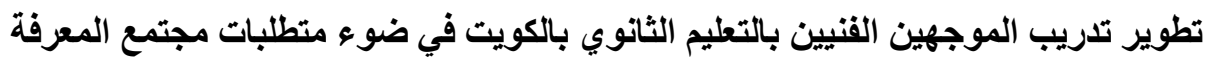

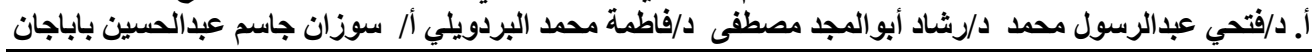

\begin{tabular}{|c|c|c|c|c|c|c|c|c|}
\hline 雪: & النسبة & الانحراف & المتوسط & $y$ & حد مالي & نعم & العبار ات & 5 \\
\hline 7 & VY,TM & $\cdot, \wedge r$ & $r, I V$ & 11 & $1 \cdot 7$ & $1 \leqslant 7$ & 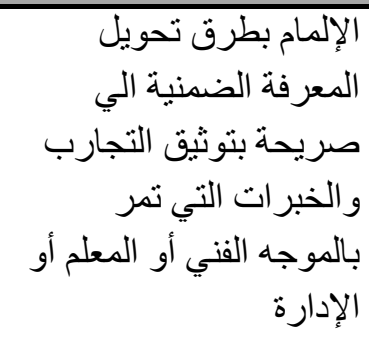 & 1. \\
\hline$\varepsilon$ & $\Lambda \tau, T \vee$ & $\cdot, 7 V$ & $r, T$ & $\varepsilon r$ & V. & 101 & العمل الإمام بمهار ات بناء فريق & 11 \\
\hline 1 & 90 & $\cdot, r q$ & $r, \wedge 0$ & - & 7. & YI. & استخذام التوجيه & IT \\
\hline 7 & VY,TM & $\cdot, \wedge r$ & $r, I V$ & 11 & $1 \cdot 7$ & $1 \leq 7$ & القارة القرة عاعهى امتلاك المعرفة خلال & r \\
\hline r & $9 \pi$ & $\cdot, \leqslant Y$ & $r, \vee q$ & $1 \cdot$ & V. & 19. & الافتر اضية. الإيجابي مع البيئات & $1 \varepsilon$ \\
\hline & $10,7 V$ & •, .09 & Y,OV & TV & $\begin{array}{l}11 \pi \\
\varepsilon\end{array}$ & $\begin{array}{c}T M V \\
T\end{array}$ & المتوسط العام للبعد ككل & \\
\hline
\end{tabular}

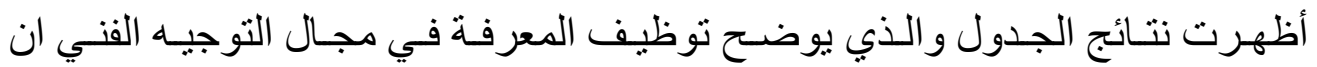

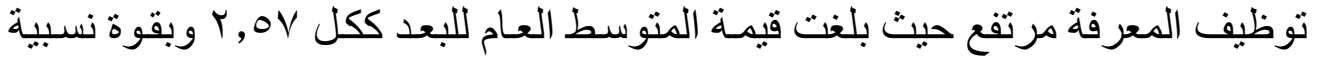

\section{يوضح ترتيب محاور الدراسة حسب قيم متوسطاتها}

\begin{tabular}{|c|c|c|c|c|}
\hline الترتيب بين المحاور & درجة الحاجة & المتوسط الحسابي & المحور & م/ الاستباتة \\
\hline الثاني & كبيرة & $r, \Sigma T$ & توليد المعرفة & 1 \\
\hline الثالث & كبيرة & $Y, \Sigma)$ & نشر المعرفة & r \\
\hline الاول & كبيرة & Y,OV & توظيف المعرفة & $r$ \\
\hline
\end{tabular}

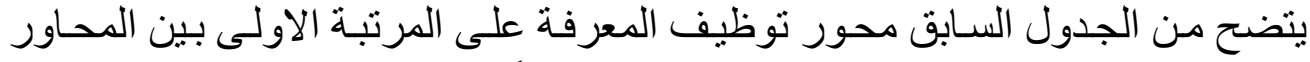

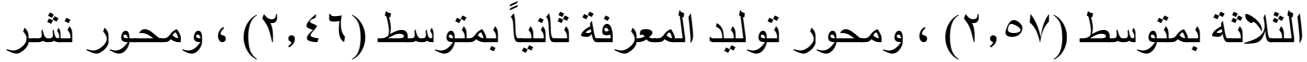
المعرفة ثالثاً بمتوسط (Y, (Y, ) . (Y) 


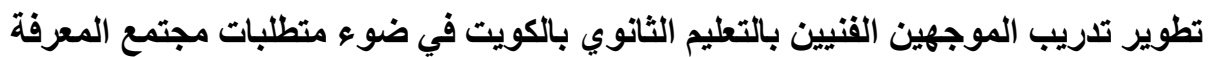

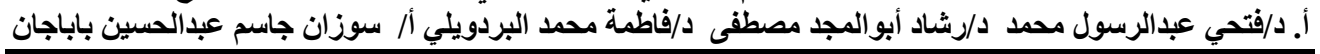

التصور المقترح

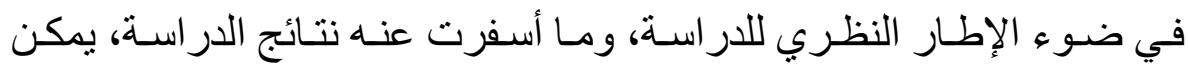
وضع التصور المقترح وفقًا للمحاور التالية: 1 - منطلقات التصور المقترح :

في ضوء مـا تم عرضـه في الإطـار النظري من أدبيـات حول تطوير تدريب

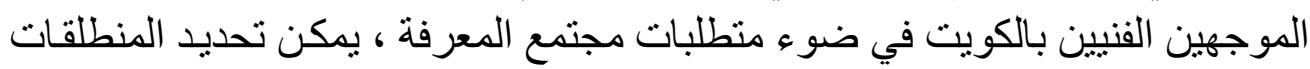

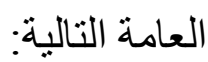

- - تأتي فاعلية الموجهين الفنيين من قدرتها على تحقيق أهداف النظام التعليمي

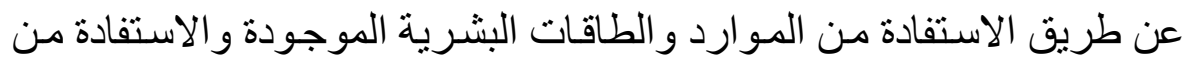
الاتجاهات الحديثة في التعليم.

- - تتحقق فاعلية الموجهين الفنيين بتقييم عمل المديرين والطلاب في المدرسة.

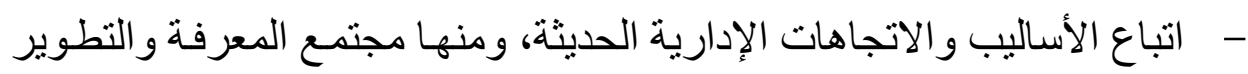

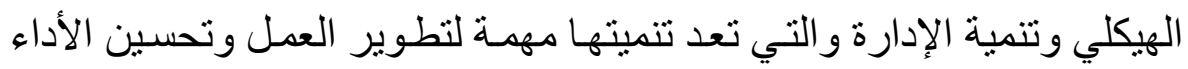

للموجهين الفنبين.

- التأكيد على دور الموجه الفني في التغيير و التطوير الإداري . - - مرورة بث فلسفة مجتمع المعرفة والتعاون المشترك لتسهيل المهمات.

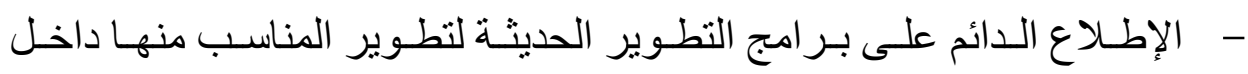
المنظومة التعليمية. - - الاستفادة من الأبحاث العلمية الحديثة وتطبيقها إلى جانب الرؤى الابتكارية في

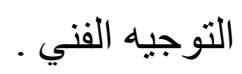
- مرورة البحث و التطبيق و التعاون و الجدية.

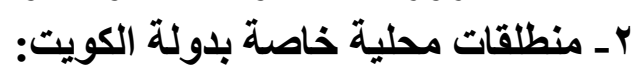

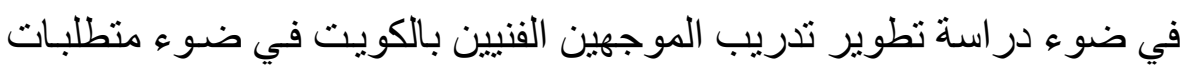

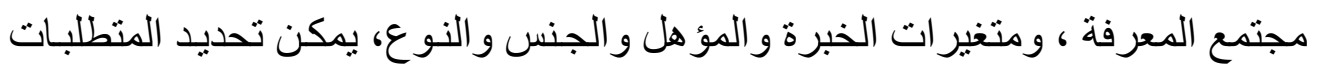
الخاصة بدولة الكويت فيما يلي: - - سعي المجتمع الكويتي إلى مواكبة التطور و التقدم الحاصل في كل المجالات العلمية. - وضع أهداف محددة وو اضحة المعـالم للتوجيـه الفني بوزارة التربيـة و التعليم بدولة الكويت. 


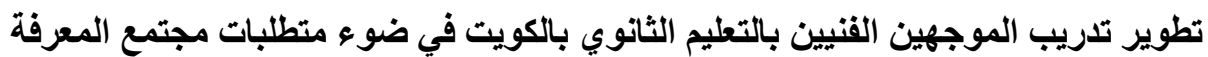
أ. د/فتحي عبدالرسول محمد د/رشاد أبو المجد مصطفى د/فاطمة محمد البردويلي أل/ سوزان جاسم عبدالحسين باباجان

- تفعيل نظام عملي مرن يعمل على تسـيل المهام و المطالب للأفر اد و العاملين بالوزارة. - ماري

- - العمـل على تنميـة قدر ات المـوجهين بشـكل مسـتمر لتطـوير أداء المنظومـة التعليمية.

- - دعم المعرفة الدينية و الوطنية للموجهين الفنيين عن طريق البر امج التطويرية. - - مرورة تطبيق فلسفة مجتمع المعرفة في التطوير. - - ضرورة تشجيع الموجهين الفنيين على التفكير و التخطيط. rـ فلسفة التصور المقترح :

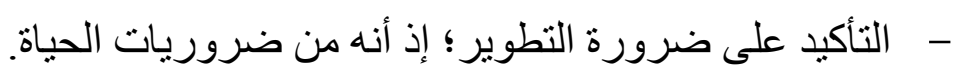
- - القوة البشرية هي العنصر الأساسي في إصلاح التطوير المهني ونجاحه.

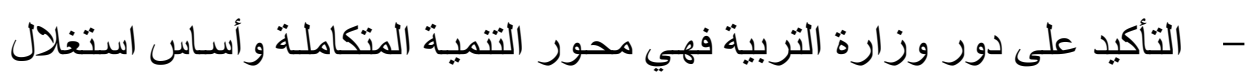
الطاقات البشرية.

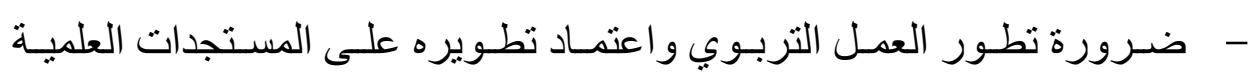

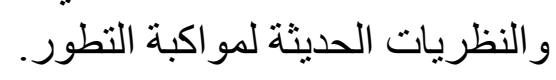

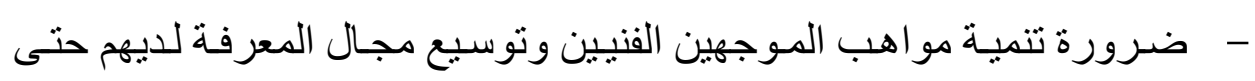

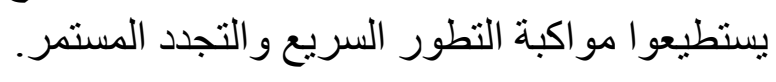
- تقوية قدر ات الموجهين الفنيين وتزويدهم بمـا يكفي من المهار ات و المتطلبات اللازمة للقيام بأعمالهم.

- - أهمية اتقان وتميز العمل ببر امج التغيير والتطوير لدى الموجهين الفنيين .

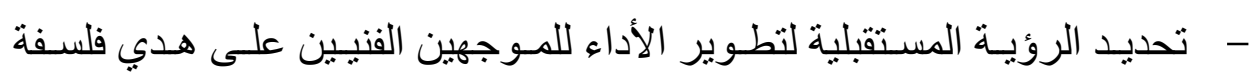
مجتمع المعرفة. - - ضرورة تعلم الموجهين الفنبين ذانًا للتمكن من القيام بأعمالهم. ؛ ـ أهداف التصور المقترح.

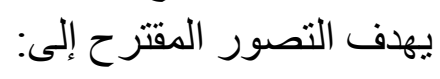

- - تقوية ودعم فلسفة التطوير لدى الموجهين الفنيين بدولة الكويت. - - الربط إيجابيًا بين فلسفة مجتمع المعرفة و أداء الموجهين الفنبين بدولة الكويت. - دعم وتقوية صفات وتصرفات وسلوكيات الموجه الفني. 


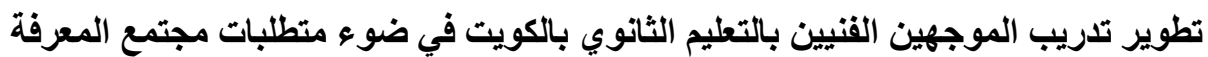
أ. د/فتحي عبدالرسول محمد د/رشاد أبو المجد مصطفى د/فاطمة محمد البردويلي أل/ سوزان جاسم عبدالحسين باباجان

- جعل دور الموجهين الفنيين و المعلمين بوزارة التربية و التعليم بدولة الكويت فعالا.

- - الاستفادة من الموارد و الطاقـات البشرية الموجودة و اتجاهـات الإدارة التربويـة

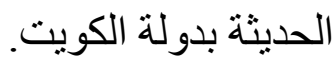

- - تكوين خطة على أساس عملي لتنمية قدر ات الموجهين الفنبين بوز ارة التربيـة

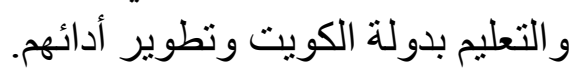
- - - إيجاد تغيير ات جوهرية في العمل الإداري القيادي.

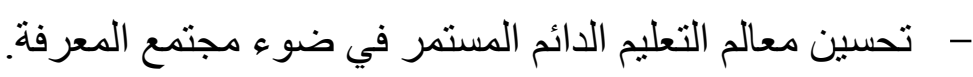

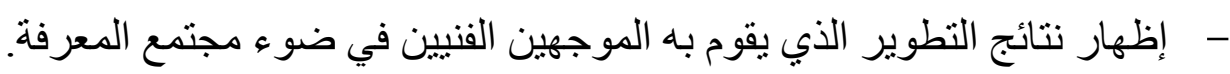

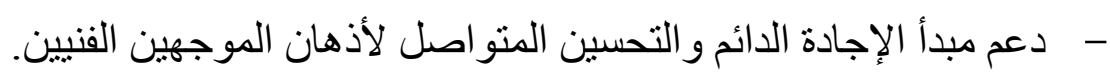
- مرض مبدأ المساو اة في فرض التدريب للموجهين الفنبين. - - دفع الموجهين الفنبين إلى الإطلاع و التقافة والتنميـة المعرفية في إطـار التعلم المستمر.

هـ أهمية التصور المقترح.

- - يقدم التصـور المقترح وجهة نظر نربويـة متطورة عن برامج التطوير لأداء الموجهين الفنيين في ضو وع مجتمع المعرفة.

- - يسهم في تجنب العثرات التي تو اجه النظم التربوية بسبب القيادة المتسلطة. - - يمكن الاعتماد عليه في تحديد إجر اءات نظم بر امج التطوير للموجهين الفنبين. - - يعد أداة قوية لظهور اتجاه التغيير لبر امج تطوير أداء الموجه الفني دون إغفال التهال

$$
\text { الظروف التي يمر بها العالم. }
$$

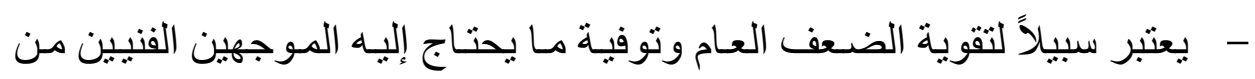

$$
\text { تدريب و احتياجات. }
$$

- - هو خطوة على طريق التغيير والتطوير استفادت مما سبقها من خطوات ويمكن

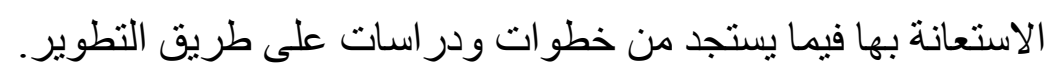

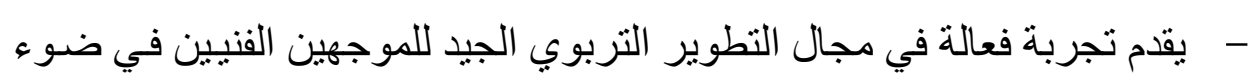
مجتمع المعرفة.

- - تعتبر وسيلة ضرورية تفرضها طبيعة المهام المر ادة في المستقبل. 


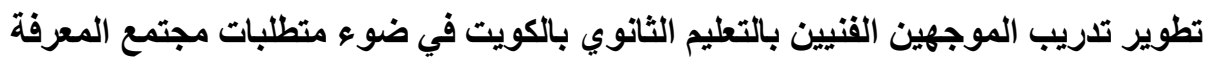

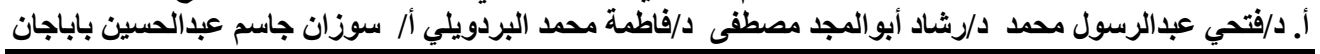

- - يثارك في فهم ومعرفة التغير ات و العلوم و الرؤى و الأسس المهنية التي تقدمها

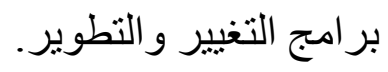

- - يعتبر مقدمة عملية لتطبيق النظم الإدارية الحديثة بالمدارس.

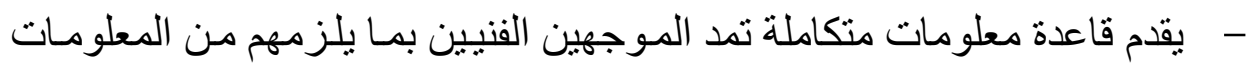
اللازمة لمهامهم.

- - يعتبر مرجعا معتدلاً يتم على أساسـه الحكم على قوة برنـامج التطوير وحسن

\section{تطبيقه.}

צ- مجالات التصور المقترح ومعاييره.

وتثمثل في: والات التهور

أـ الروية المستقبلية: وتتحدد بأن يتم رفع قدر الأداء للموجهين الفنبين عن طريق

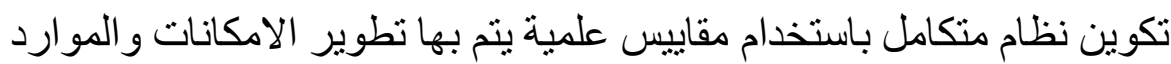

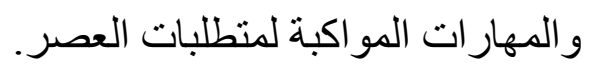

بـ دور التصور المقترح: يأتي دور التصور المقتر التهر مع الاعتبار ات التالية:

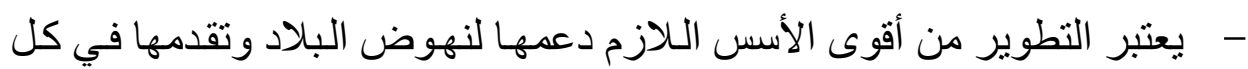

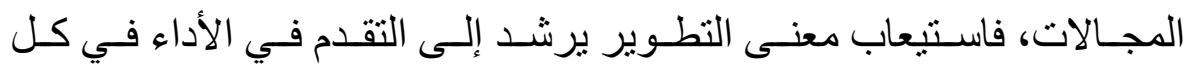

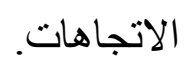

- تعتمد بر امج التطوير في التوجيه الفني على منهاج واضح في التجهيز للبر امج التهي

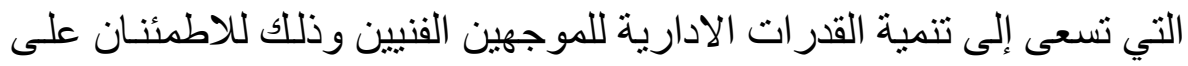

$$
\text { فائدتها وجودنها. }
$$

- - يدعو التطوير إلى تقدير الموجـه الفني واحتر امسه ومعرفة قدرتـه على توفيق الفي

$$
\text { أوضاع العمل الفني. }
$$

$$
\text { - - إعداد مقاييس لضمان الجودة في الأداء الفني. }
$$

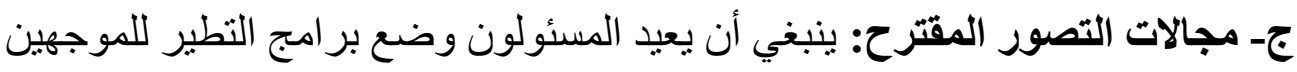

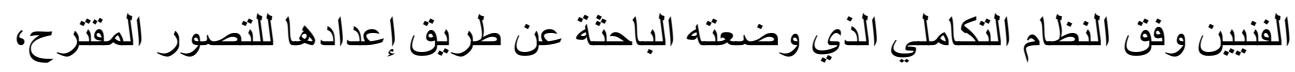
وهو كالتالي:

المجال الأول: أهداف التفيير الإداري

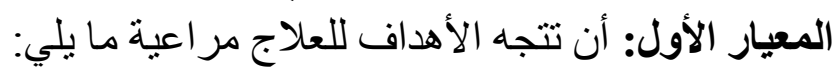

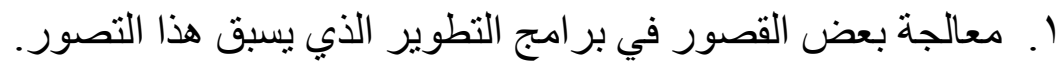
r r . معالجة التقصير في الجانب الأدائي. r. الاستفادة من الأساليب الحديثة. 


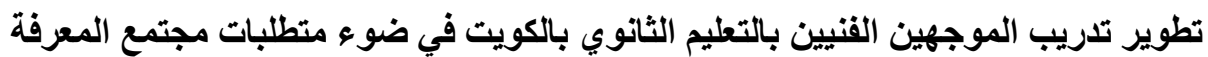

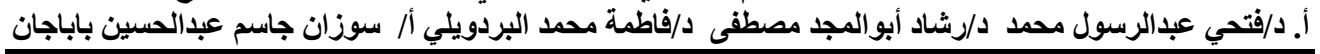

$$
\text { ع. استخدام مبدأ مجتمع المعرفة في التطبيق. }
$$

○. تساعد في فهم بعض المصطلحات المتداولة في العلوم الإدارية والتربوية لتطوير قدرة الموجهين الفنيين.

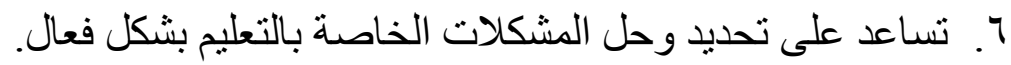
المعيار الثاني: أن تتجه الأهداف للتأهيل مر اعية ما يلي:

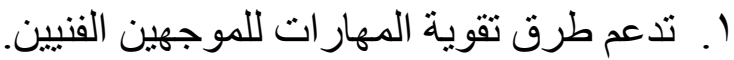

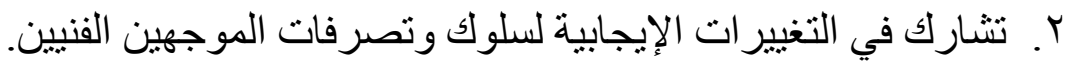

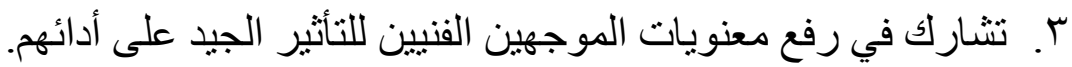
؛. تشارك في ترسيخ القيم و الإيجابيات في التعامل مع المعلمين.

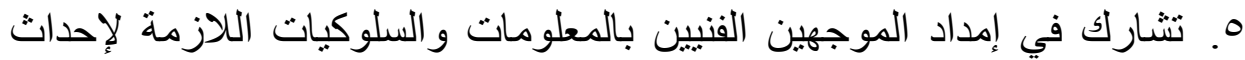
تأثثير جيد ملموس في التعليم العام.

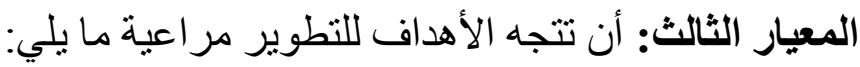
ا ا. مو اكبة التحديات الحديثة التي تمر بالعالم كله.

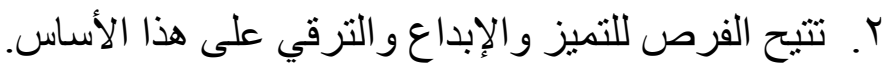
r. تدعو إلى القراعة وتوسيع دوائر المعرفة. ع. تشارك في رفع معنويات الموجه الفني لدعم أدائهم إدارًيا. •. تشارك في ترسيخ القيم والإيجابيات في تعامل الموجهين الفنيبين مع المعلمين

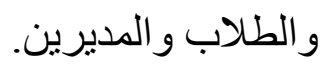

\section{المجال الثاني: ما تثتمل عليه برامج التطوين التطوير}

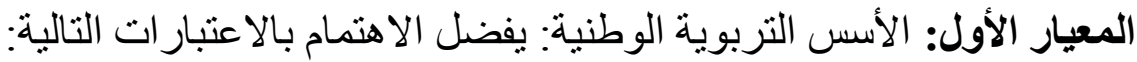

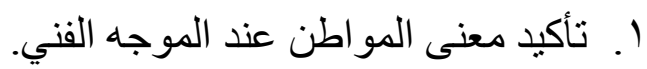
r. الإكثار من الدورات التدريبية.

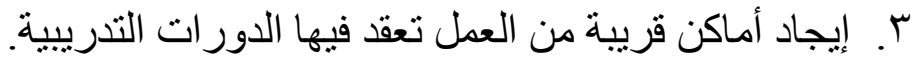

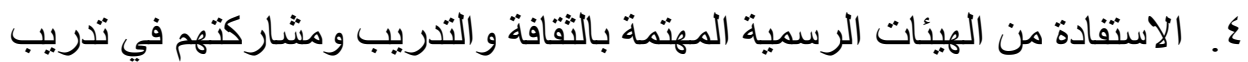
الموجهين الفنبين. ๑. التوفيق بين الجانبين النظري و العملي في التدريب.

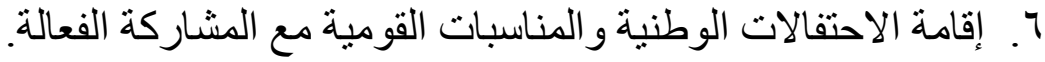

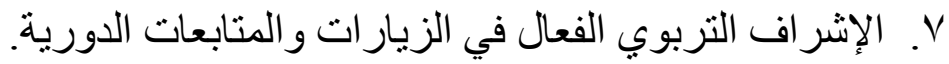
المعيار الثاني: تجهيز مواد التدريب:

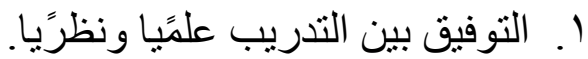
Y. إيجاد المو اد اللازمة للتدريب و الاستفادة منها. 


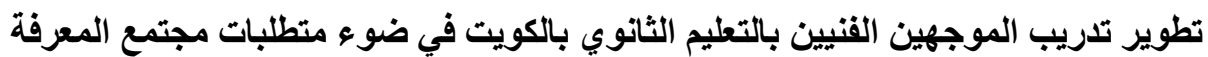

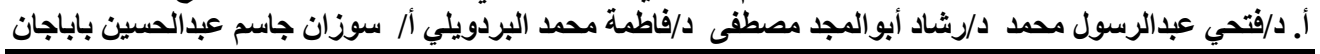

r. الاستفادة من التكنولوجيا المناسبة للتدريب و الاستعانة بالتقنيات الحديثة.

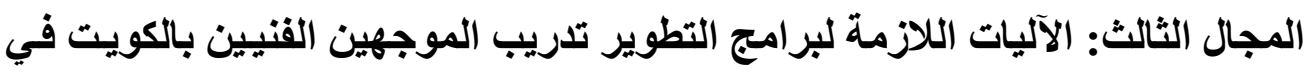
ضوء متطلبات مجتمع المعرفة:

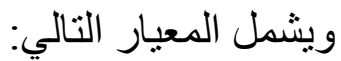

المعيار: سبل و أساليب التطوير ، ويمكن عرضها مع الاعتبار ات التالية:

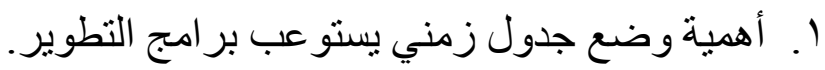

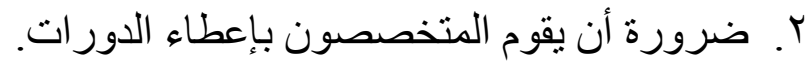

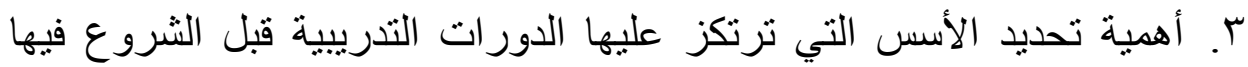

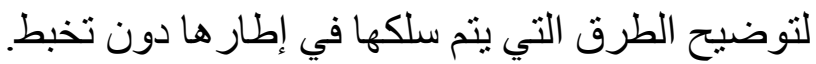

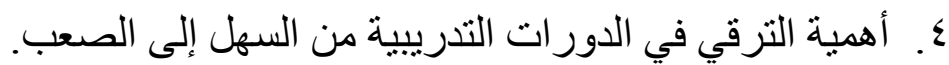

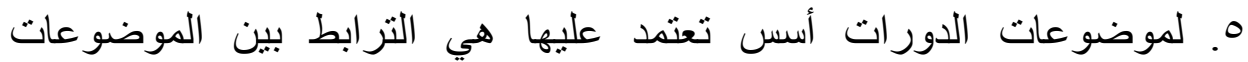
و الاستمر ار و التنويع و التعدد و المشاركة وباتلتالي الجلسة الختامية.

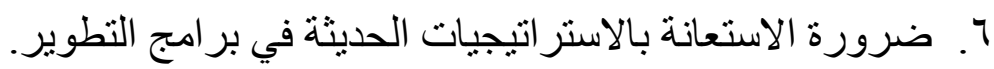

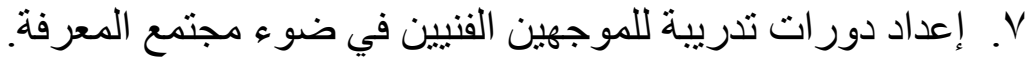

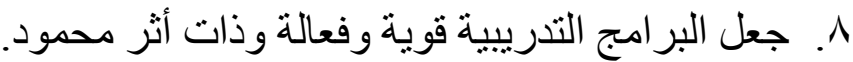
9. جعل بر امج التأهيل للموجهين الفنبين فعالة ومؤثرة.

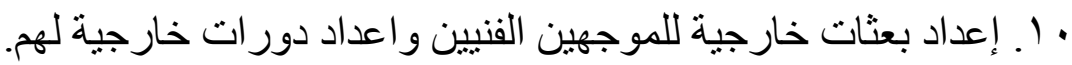

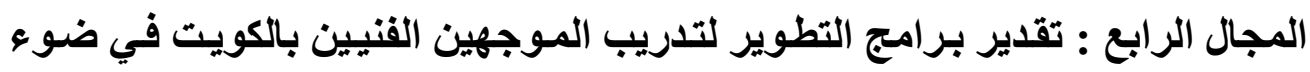
متطلبات مجتمع المعرفة :

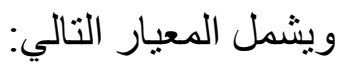

المعيار: يفضل من المسئولين إفادة إعداد برامج التطوير متفقة مع الأساليب التقديرية الآتية :

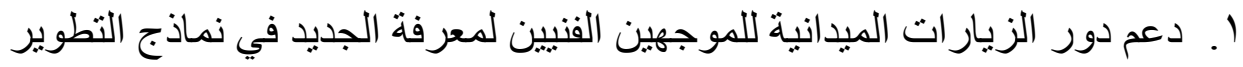

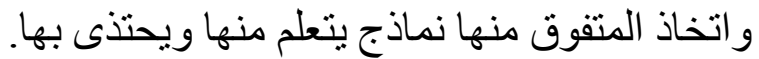

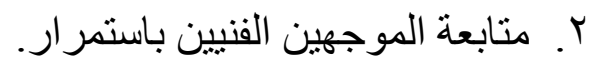

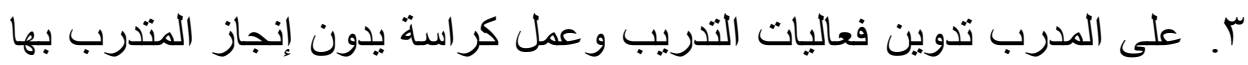

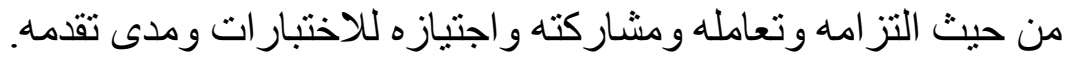

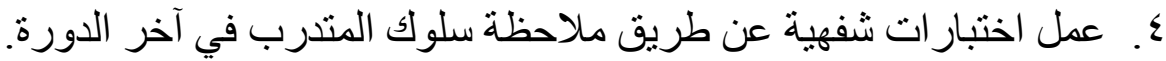
๑. عمل اختبار ات تحريرية في آخر الدورة. 7. عمل اختبار ات تكنولوجية آخر الدورة آنية.

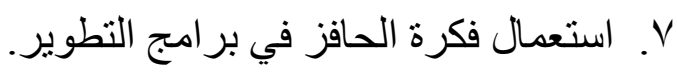
^. ضرورة التزام المقاييس المنبعة لتحديد مستوى الأداء وجودئه. 


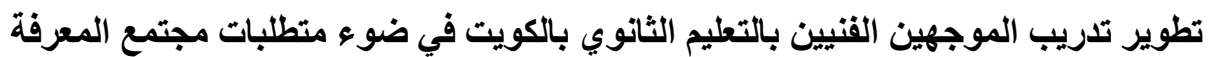
أ. د/فتحي عبدالرسول محمد د/رشاد أبو المجد مصطفى د/فاطمة محمد البردويلي في أل سوزان جاسم عبدالحسين باباجان

$$
\begin{aligned}
& \text { 7- أبعاد التصور المقترح: } \\
& \text { تتمثل أبعاد التصور المقترح فئرح المئ } \\
& \text { أ) تظوير نظام العمل داخل المدارس: }
\end{aligned}
$$

ا ـ تدريب الموجهين الفنيين وتقويتهم علمَيا وتعريفهم بأساليب القيادة الحديثة؛ مما

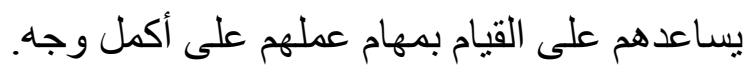

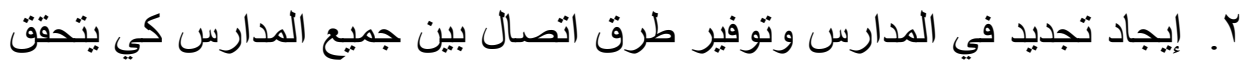

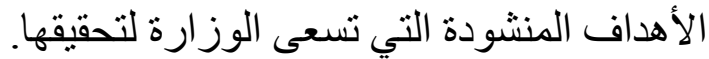

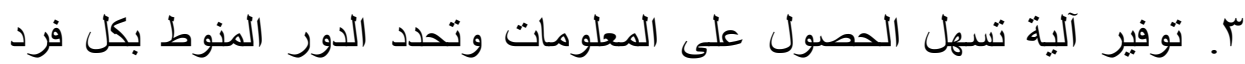

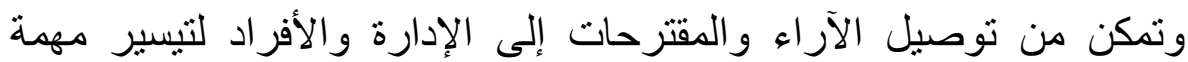

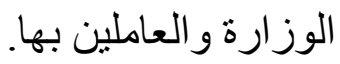

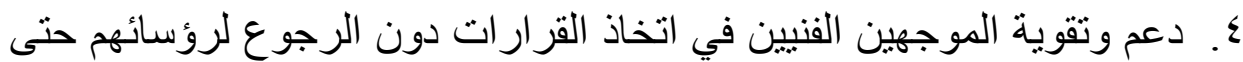

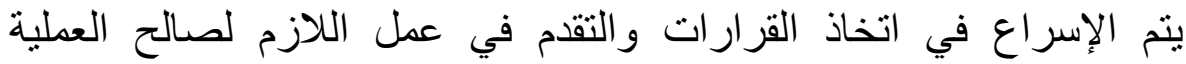

$$
\text { التعليمية. }
$$

0. ترسيخ فلسفة التدريب و التنمية البشرية داخل الإدار ات التعليمية.

ب) اعتماد الموجهين الفنيين على الأجهزة الإلكترونية لتطوير أدائها :

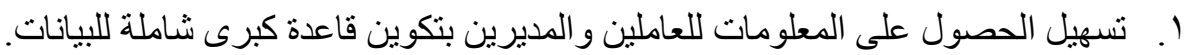

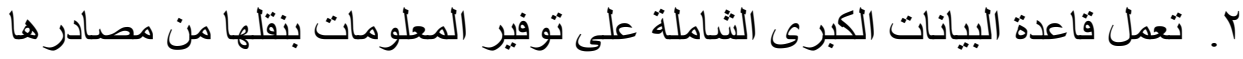
ثم معالجتها ونشر ها لدى طالبيها من العاملين وتساعد هذه القاعدة في إصدار القرار ات وتوثيق المعلومات. r. ضرورة الاستفادة من المقاييس العلمية في اختيار القيادات القادرة على إدارة

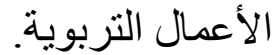
ع. تأدية العمل بإخلاص و الوضول الإلة في تنفيذ خطو اته. ○. الحرص على الإبداع والتطوير في العملية التربوية.

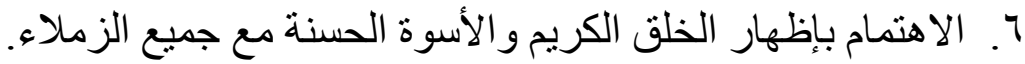
V- متطلبات تطبيق التصور المقترح.

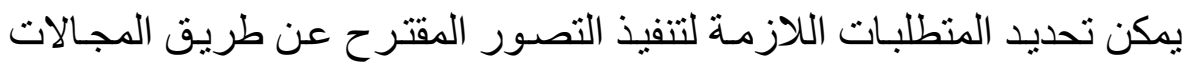

أـ العمل على تطوير كافة المجالات، ومنها:

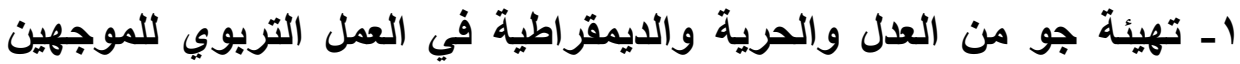

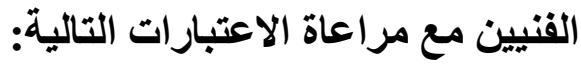
- - - إرساء قيمة الديمقر اطية في التعليم. 


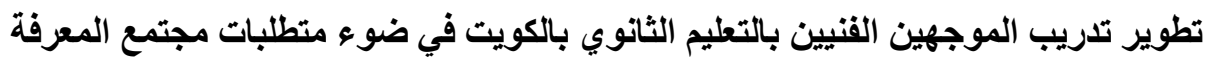

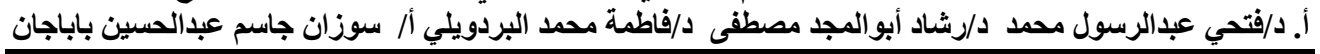

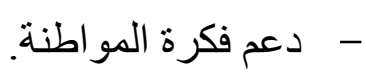

- توفير تكافؤ الفرص بين المتدربين من الموجهين.

- ترك الموجهين الفنيين يحدون ما يحتاجو إليه بحرية تامة.

- - ضرورة تحديد زمن لعمل الدورات يكون مناسبًا لظروف الموجهين الفنيين الاجتماعية.

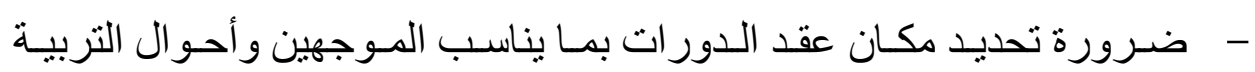
ومناطق الإقامة. - مانة

- - الابتعاد عن الأسلوب الثابت النمطي في التعامل مع الموجهين الفنيين. - عقد اجتماع، ولو واحَدا في السنة للتحدث حول مشكلات الموجهين الفنبين. - - إعداد صندوق للاقتر احات و الثكاوي بكل الموجهين التابعين لوز وارة التربية. - عمل جمعيات نربوية للموجهين الفنيين. ץ ـ تعديل الأسس التي على ضوئها تصدر التعليمات للموجهين القنيين متفقة مع الفئ

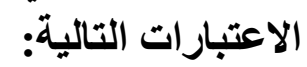

- - القيام بتعديل لشروط التقدم للجوائز الكبرى ليتسنى الموجهين المشـاركة فيها وكذللك زيادة عدد المشتركين و الفائزين. - - إعداد صندوق للاقتر احات بكل المناطق. ب- توفير كافة المتطلبات اللازمة لتطوير الموجهين الفنيين، ومنها:

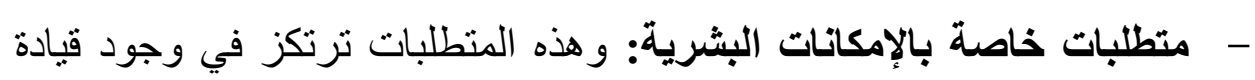

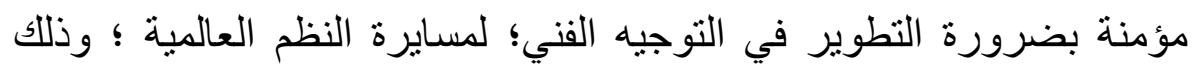
لرفع مستوى أداء الموجهين الفنبين.

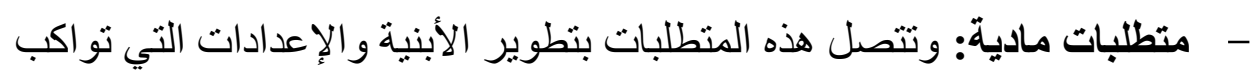
المستحدثات التكنولوجية. - متطلبات مالية: وتتصل بتوفير الجوانب المالية التي يلزم اعتمادها لتطوير

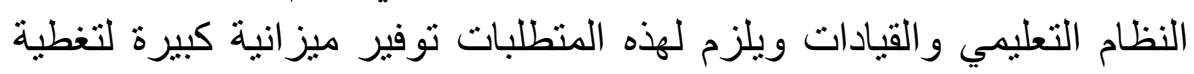
التكاليف المطلوبة. ᄉـ معوقات التصور المقترح.

توجد معوقات متنوعة، منها: البشري و الإداري و التنظيمي و التكنولوجي، ويمكن

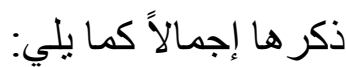

- تعود الأفراد والموجهين الفنيين على طريقة من العمل يأبون تغييرها ويرفضون ويتصدون لأي محاولة للتجديد. 
- - الكثير من الموجهين الفنيين يفضلون العمل بشكل فردي. - - بعض من مدربي الموجهين الفنيين يفضلون العمل بشكل فردي.

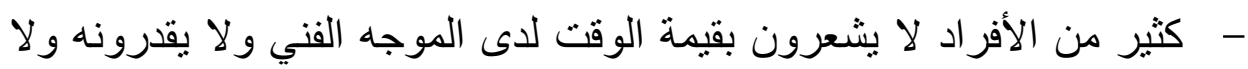
يسنطيعون الإفادة منـه.

- - تقدير العمل لدى الكثيرين يشوبه عامل العلاقات الثخصية. - التخوف من فكرة التغيير عند الموجهين الفنيين. - - انتظار تحقيق نتائج سريعة دون النظر إلى المدى المستقبلي.

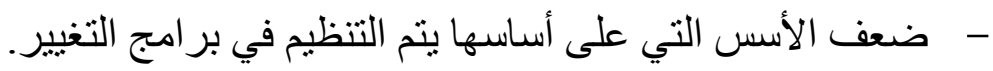
9-سبل التظلب على تلك المعوقات.

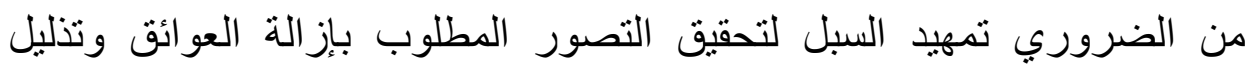

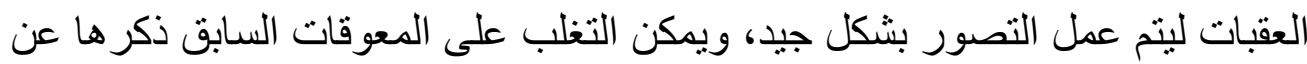

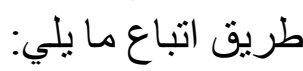
- - إعداد الموجهين الفنيين و الأفر اد لتفبل التجديد المنتظر إيجاده بالنظام التعليمي. - - دوام التغيير للموجهين الفنبين داخل الوزارة. - التعريف بأهمية الوقت وضرورة الاستفادة منه وحسن استغلاله.

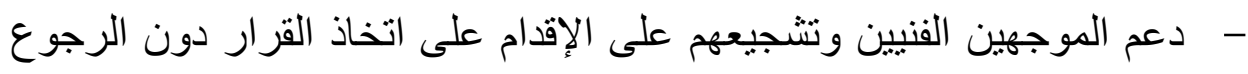
لنأعلى في النظام التعليمي. - - تقدير العمل بشكل عادل دون مجاملة أو محسوبية. - أهمية إعداد هيئة كبرى لتنفيذ البرنامج عن طريق التنسيق للأعمال وتحديد الأهم منها. - - مرورة الاهتمام بالحفاظ على الهوية العربية الإسلامية وترسيخ مبدأ الإنتماء. - - دعم قيم إتقان العمل وتقوية الرو ابط الأسرية والانتماء للمجتمع و الوطن. - - دعم قيمة العمل الجماعي و العمل الفردي ومشاركة إصدار القرار. - تحديد مو ارد مالية للبر امج التدريسية. - - تقوية دور البر امج التدريسية والتطوير و التأهيل. 


\section{نتائج الار اسة \\ اولا : نتائج الار اسة النظرية}

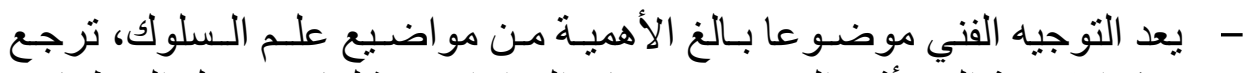

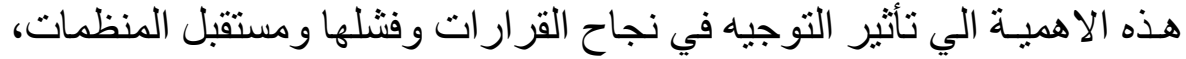

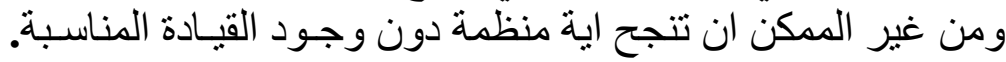

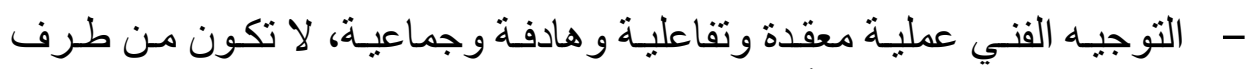

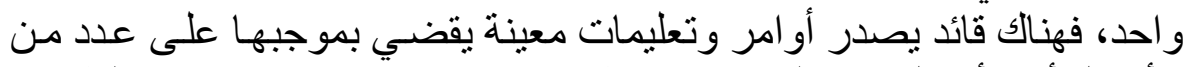

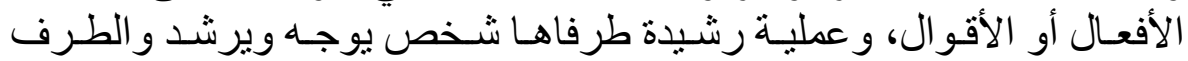

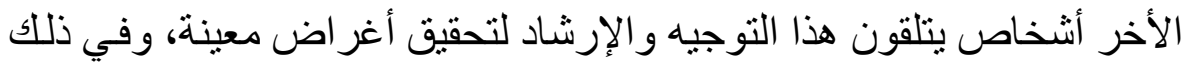

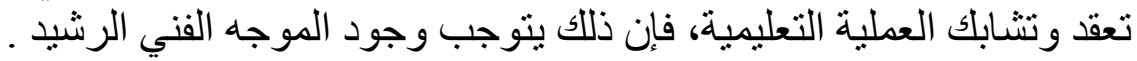

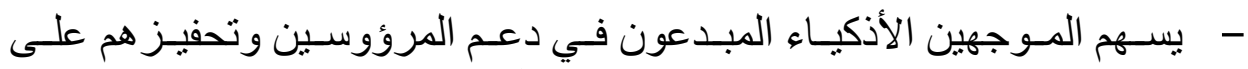

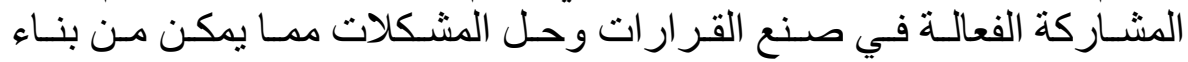

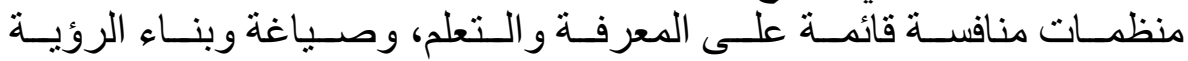

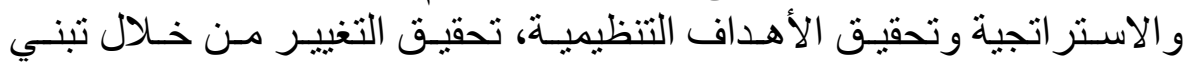

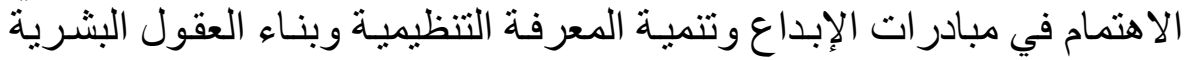

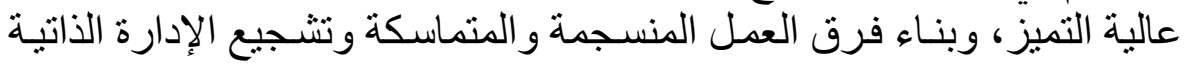

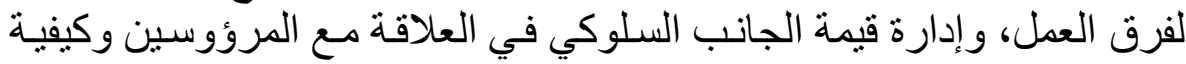
حفز هم للعمل فاعلية.

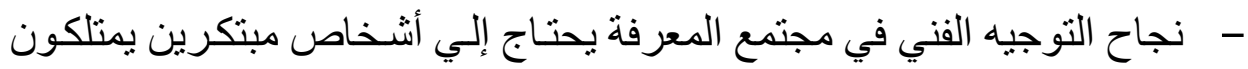

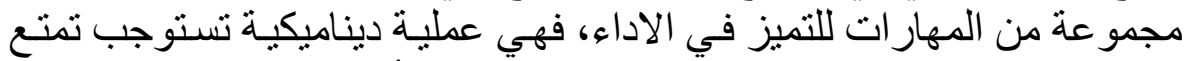

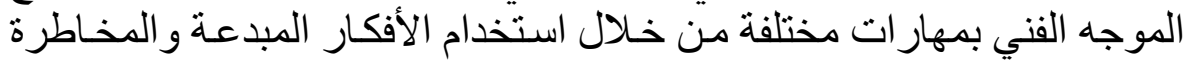

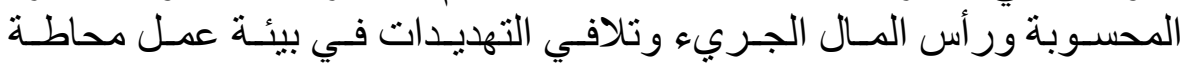
بالمخاطر و التحديات و المنافسة.

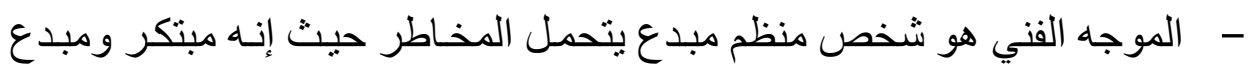

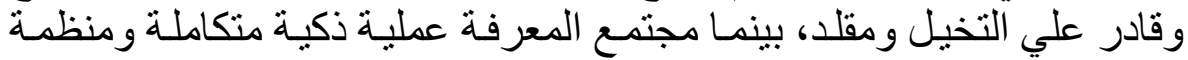

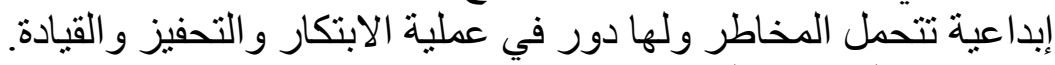
ثانيا : نتائج الدراسة الميدانية

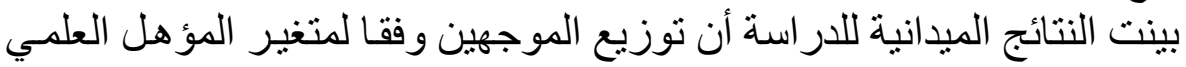

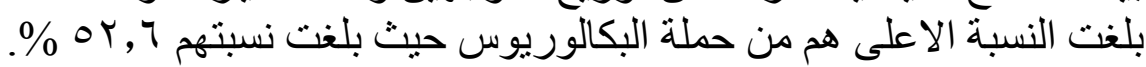

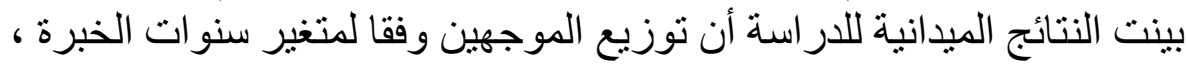

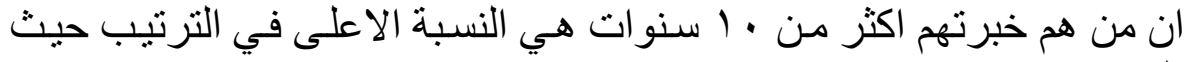

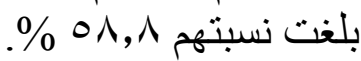

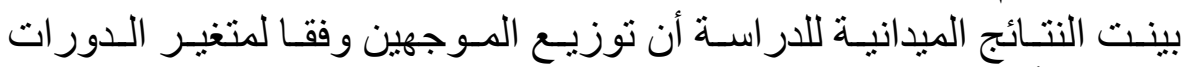
التدريبية أن من الحاصلين على دورتان هم النسبة الاعلى في في الترتيب حيث

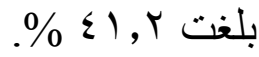




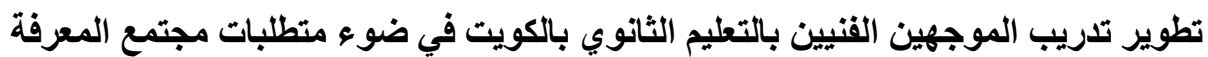

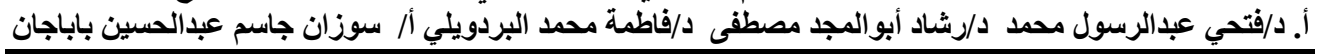

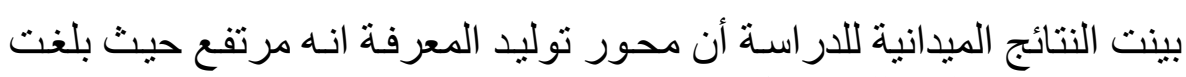

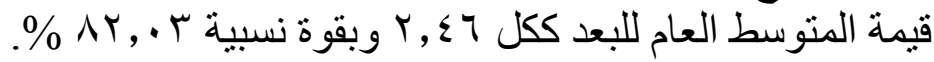

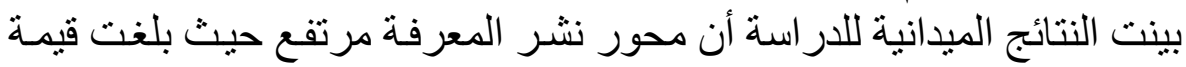

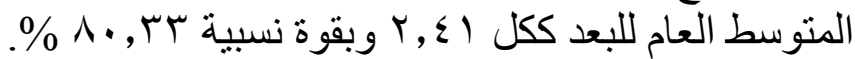

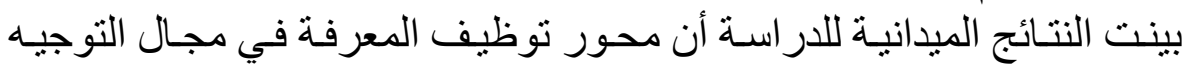

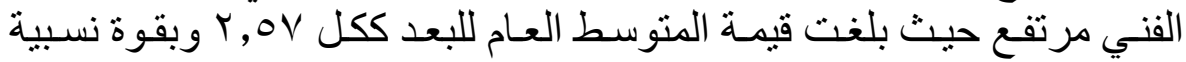
$\%$ \% $10,7 \mathrm{~V}$

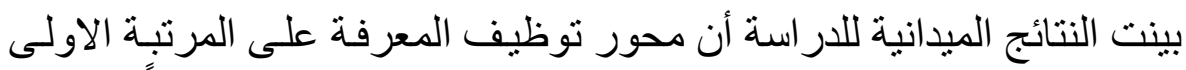

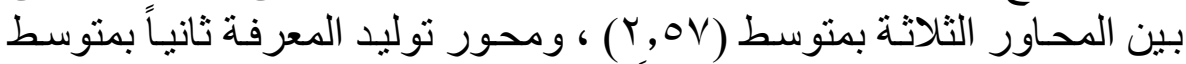

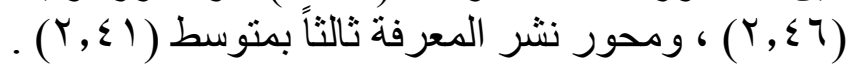

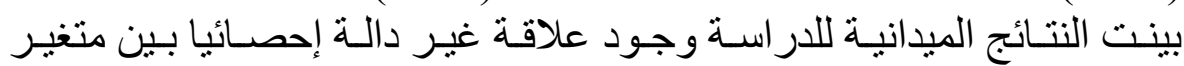

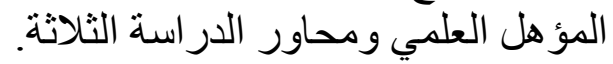

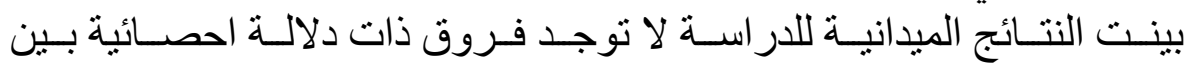

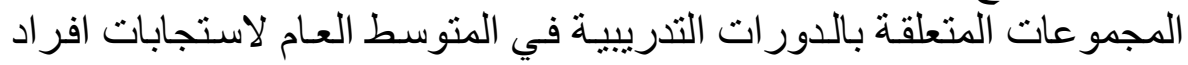

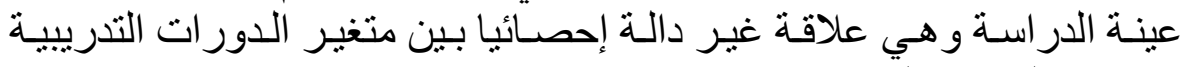
ومحاور الدراسة الثثلاثة.

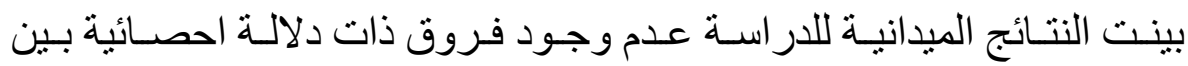

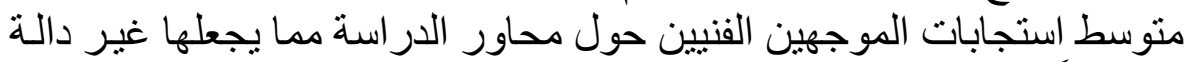
احصائياً.

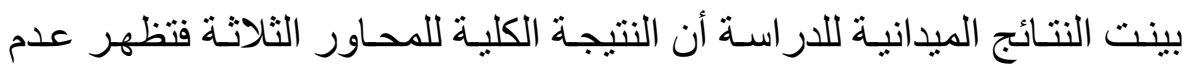

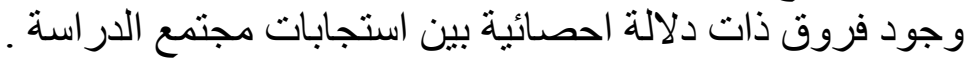




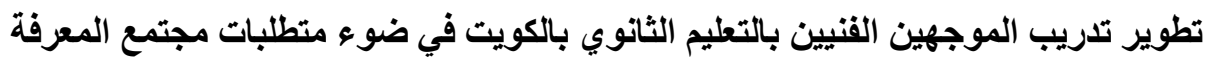
أ. د/فتحي عبدالرسول محمد د/رشاد أبو المجد مصطفى د/فاطمة محمد البردويلي أل/ سوزان جاسم عبداكئ الحسين باباجان

\section{مراجع البحث}

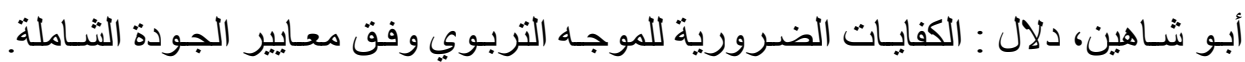

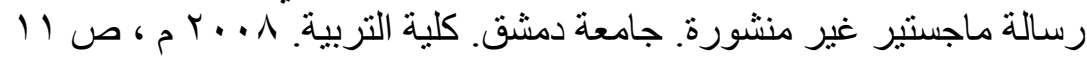

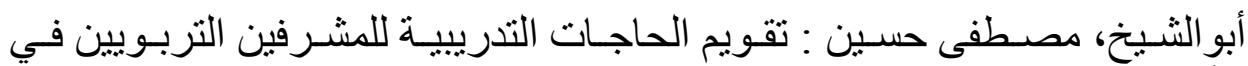

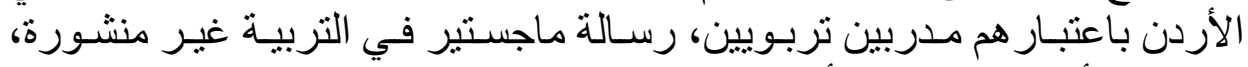

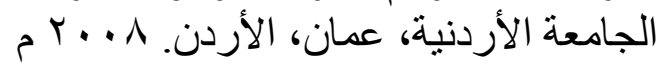

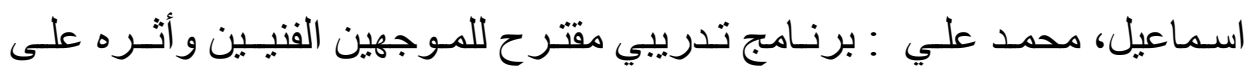

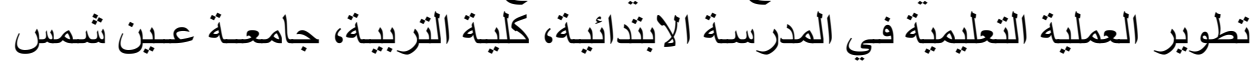

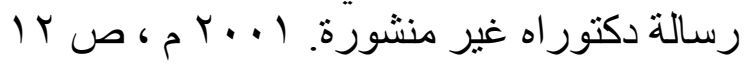

إسماعيل، محمد علي : برنامج تدريبي مقتر ح للموجهين الفنيين و أثره على تلى تطوير

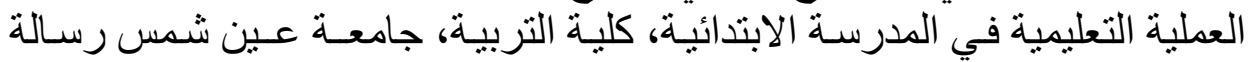

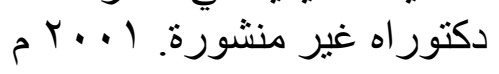

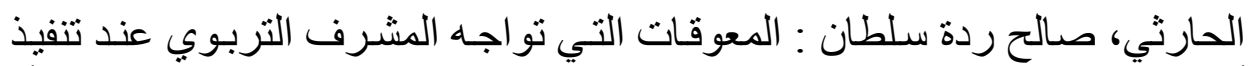

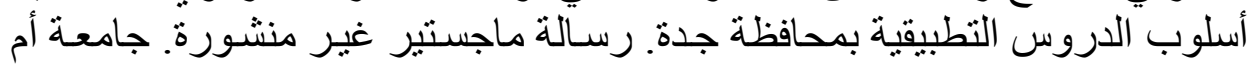

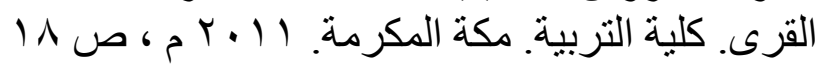

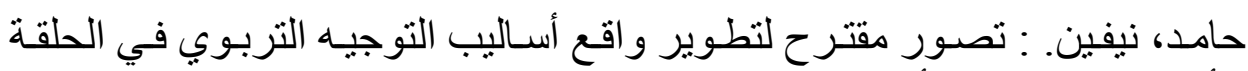

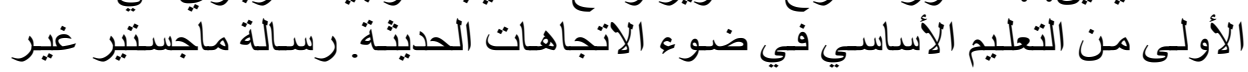

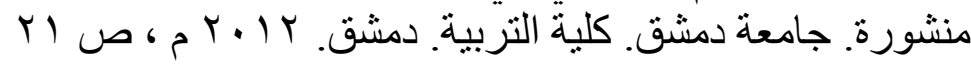

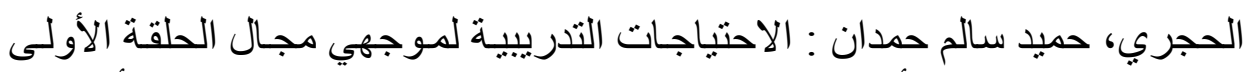

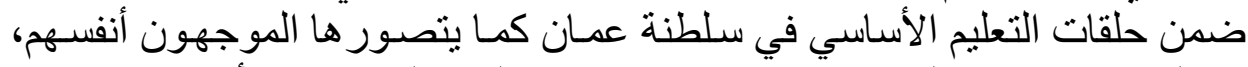
رسالة ماجستير في التربية غير منشورة، جامعة اليرموك، إربد، الأردن. ؟ . . T م

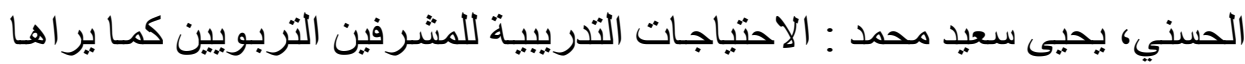

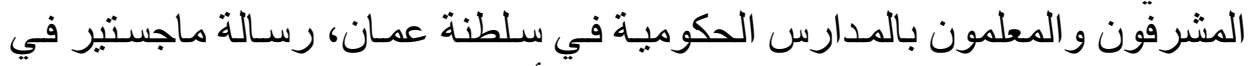

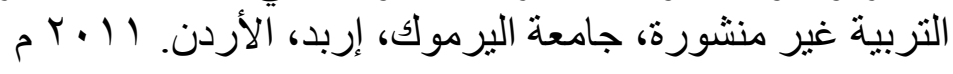

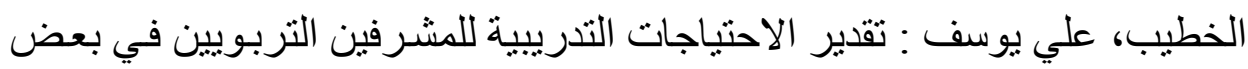

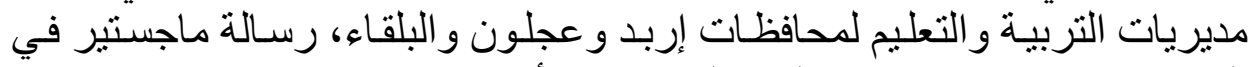

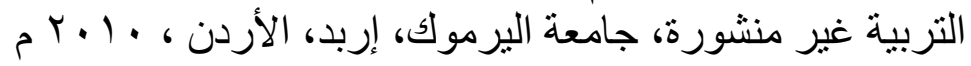

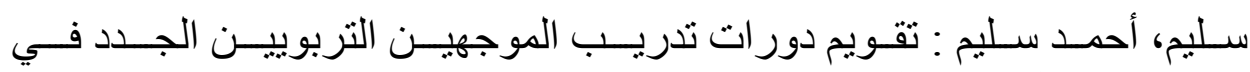

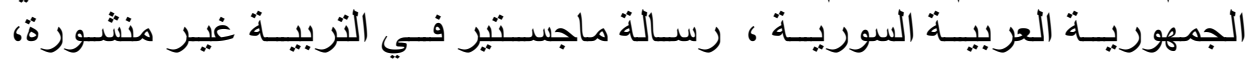

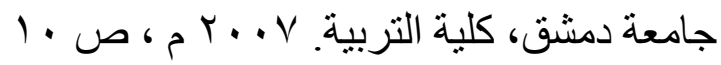




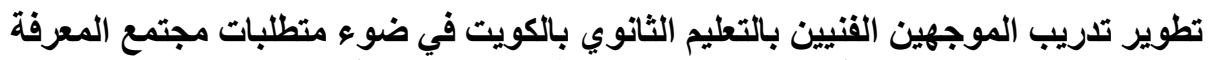

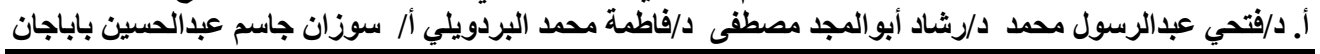

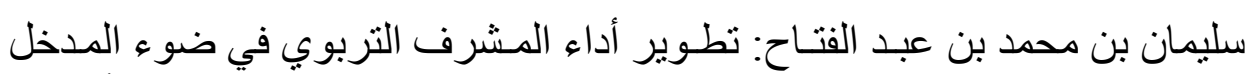

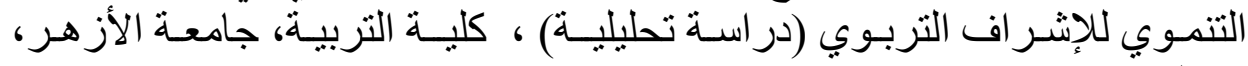

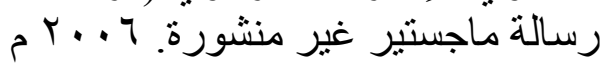

سنقر ، صالحة : نظريات التوجيه التربوي، منشور ات جامعة دمشق، كلية التربية،

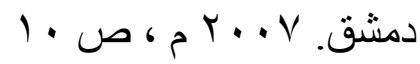

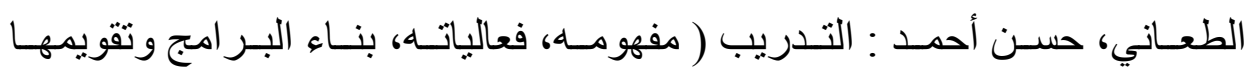

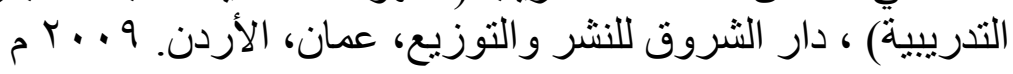

عبد الخالق سعيد عبد الله : الاحتياجات التدريبية لمديري المدارس الابتدائية بمنطقة

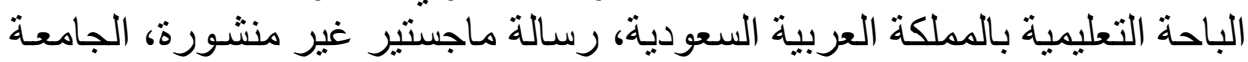

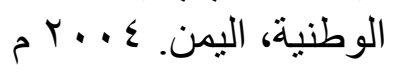

عبد القتاح، رافت السيد : سيكولوجية التدريب وتنمية الموارد البشرية. القاهرة :

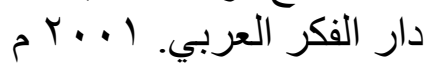

عساف ، عبدالمعطي محمد : التدريب وتتميـة الموارد البشرية الأسس و العمليات

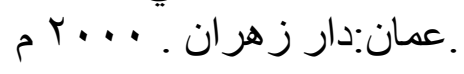

عليمات ، محمد عليان : الاتجاهات الحديثة في التعليم و التدريب و الإدارة ـ عمـان :

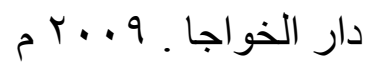

عليوة ، السيد : تحديد الاحتياجـات التدرييية ، ايتر اك للطباعة و النشر و التوزيع ،

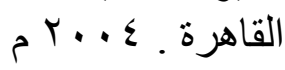

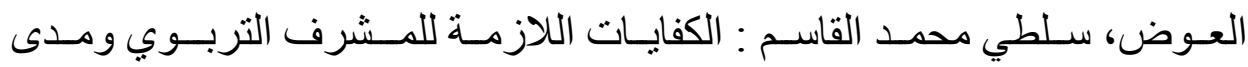

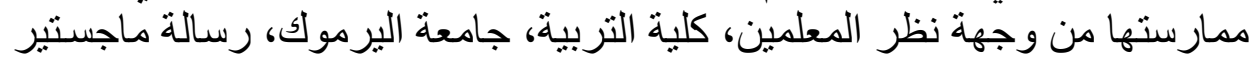

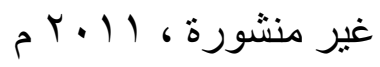

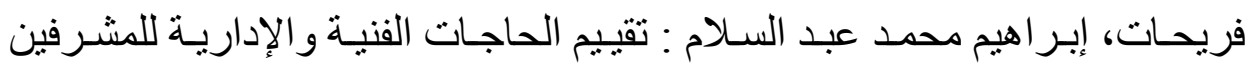

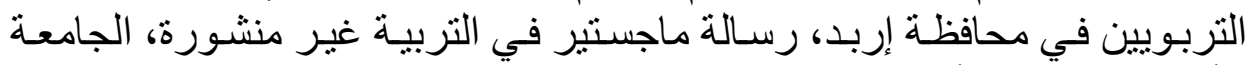

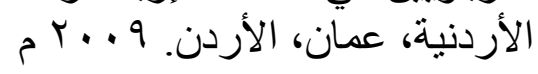

فلمبان، أميمة. : فاعلية برنامج مفترح لتدريب المشرفات التربويات على استخدام

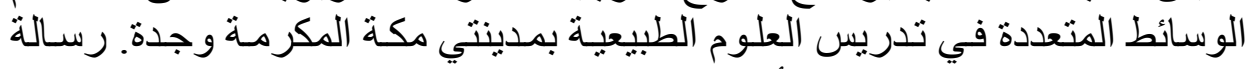

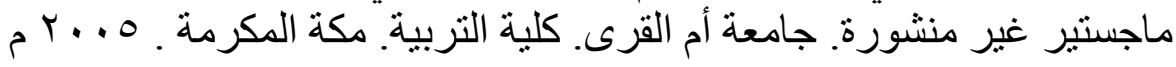




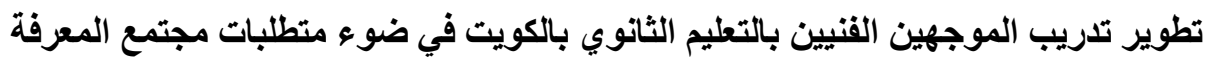

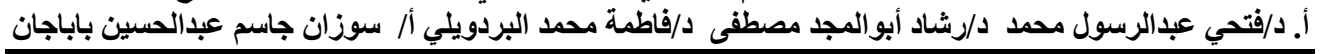

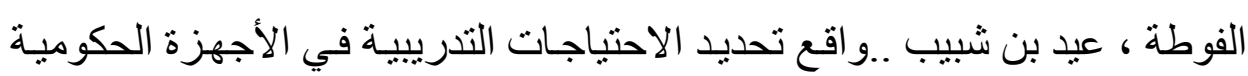

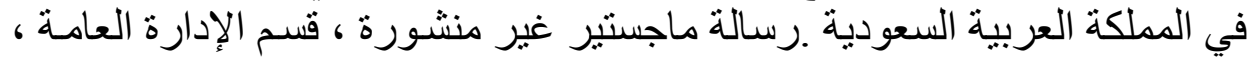

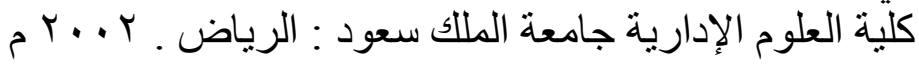

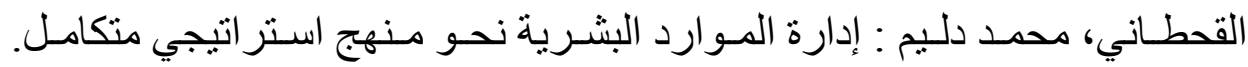

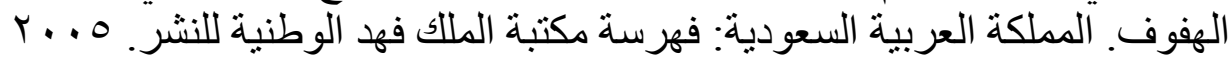

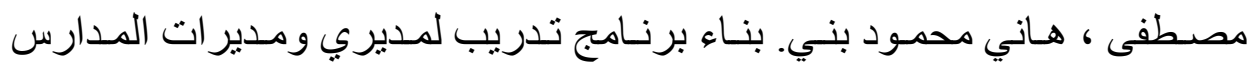

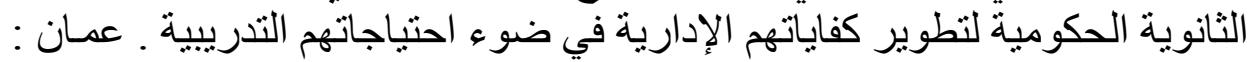

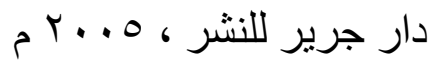

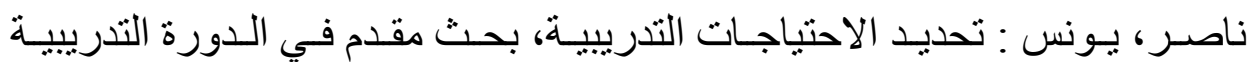

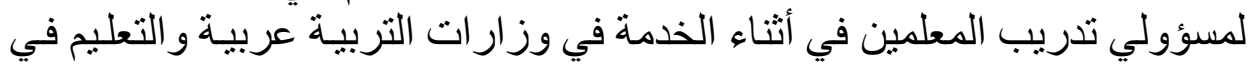

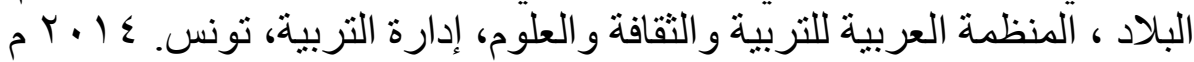

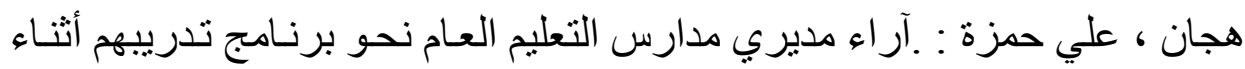

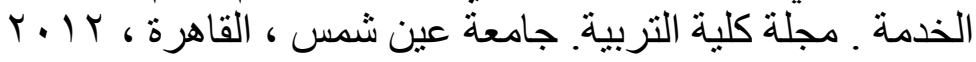

هـلال ، محمد عبد الغني . : التدريب الأسس و المبـادئ ـ مصـر الجديدة : مركز

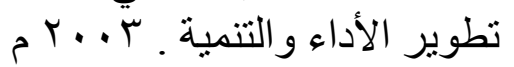

يوسف بن محمد : أسس التدريب الإداري. الرياض: دار عالم الكتب ، ب ا • م م نعيم إبر اهيم الظـا هـر : إدارة المعرفـة ، عمـان: دار جدار للكتـاب العـالمي للنشر

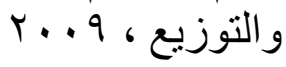

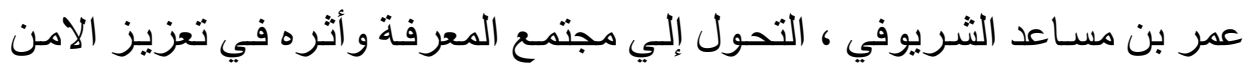

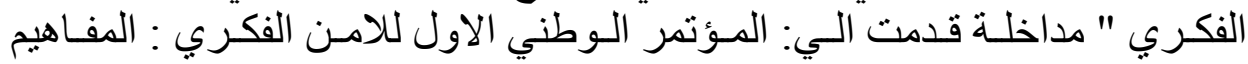

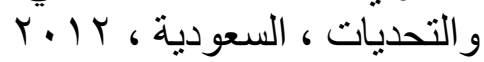

Patrick, J , Training : Research and Practice , Academic Press Inc, San Diego. 2007

Jacqueline, L:. "Confronting Challenges in Online Teaching: The Web Quest Solution". MERLOT Journal of Online Learning and Teaching. 2007

Adin, Vicky Pathways to a Knowledge Society? Implementing Objective 17 of the New Zealand Tertiary Education Strategy. A thesis in the University of Auckland .Boca Raton, 2005 


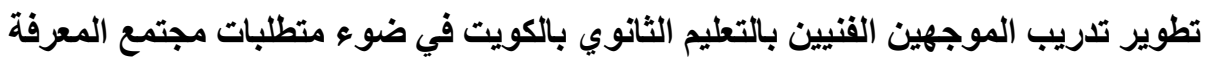

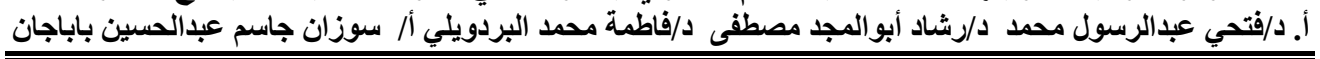

Anderson, Tim, The virtual reality, book case, new york . 2006

Booth, S. Learning and Teaching mathematics for the Knowledge Society. European Journal of Educatin, Vol. 33, No. 3, 2016 , pp. 381-389.

Brown, Alan, Limitations of Level, learning outcomes and qualifications as driven towards a more knowledge based society. Us-China Education Review. Vol. 5 No 1. 2011 , Pp. 9-17. 